\title{
INCOME TAX CLAIMS IN THE YEAR OF BANKRUPTCY: A CONGRESSIONALLY CREATED QUAGMIRE
}

\author{
Gregory L. Germain ${ }^{1}$
}

\section{TABLE OF CONTENTS}

I. The RELATIONSHIP BETWEEN PRIORITY AND DischargEABILITY...........................2

II. PRIORITY For INCOME TAX Claims IN THE YeAR OF BANKRUPTCY ......................5

1. The Lookback Rule. ...............................................................................

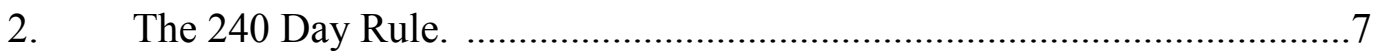

3. The Post-Petition Assessability Rule before the 2005 Act.......................9

A. $\quad$ Taxes "of a kind specified in section 523(a)1)(B) and (C)." .......9

i Late Returns Filed More than Two but Fewer than Three

Years Before Bankruptcy.................................................10

B. Pre-petition Taxes in the Year of Bankruptcy............................19

i Corporate Taxpayers ........................................................23

ii Individual Taxpayers Who Do Not Make The Split-Year

Election. .........................................................................29

C The Implication of the Post-petition Assessability Rule on

Prepetition Taxes in the Year of Bankruptcy................................39

4. The Post-Petition Assessability Rule after the 2005 Act..........................41

5. Administrative Priority Claims ..............................................................43

III. DisChARGEABILITY OF YEAR-OF-BANKRUPTCY TAX CLAIMS. ..............................46

IV. TReatment of Year-of-Bankruptcy Tax Claims In Chapter ProceEdings.

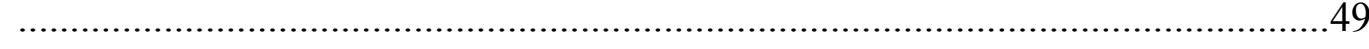

1. Treatment of Claims Against the Estate .................................................49

A. Chapter 11 Cases Prior to the 2005 Act......................................49

B. Chapter 11 Cases Under the 2005 Act..........................................51

C. The Estate's Liability for Post-Confirmation Interest and Penalties on Year-of-Bankruptcy Tax Claims............................................53

D. Chapter 12 and 13 Cases. .......................................................54

2. Dischargeability of Year-of-Bankruptcy Tax Clams in Chapter

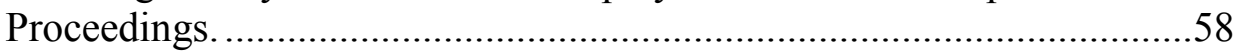

A. Chapter 11 Prior to the 2005 Act. ..............................................58

i. $\quad$ Corporate Debtors...........................................................58

ii. Individual Debtors Who Make the Split Year Election...59

\footnotetext{
${ }^{1}$ Assistant Professor of Law, Syracuse University, College of Law. B.A. University of California, Santa Cruz (1982), J.D. University of California, Hastings College of Law (1985), L.L.M. (Tax) University of Florida, College of Law (2001). The author benefitted greatly from the assistance of his research assistants at the Syracuse University College of Law, Richard Wallach, Rui O. Santos, and Kevin Roggow.
} 
iii. Individual Debtors Who Do Not Make the Split-Year Election ......................................................................59

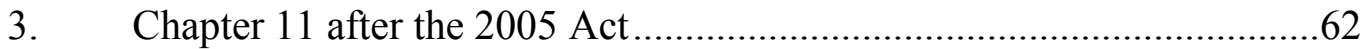

A. Corporate Taxpayers …………………………......................62

B. Individual Taxpayers …………..................................................63

C. Using a Chapter 11 Plan to Delay Payment of Non-Dischargeable

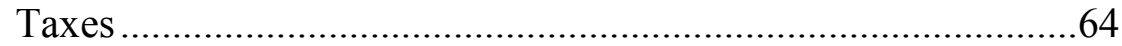

D. Claims for Interest and Penalties on Non-Dischargeable Taxes in

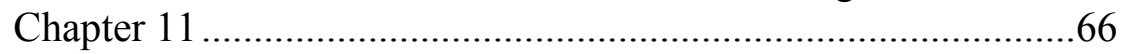

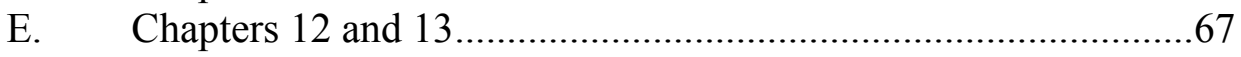

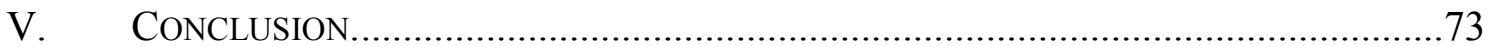


Whenever a debtor files bankruptcy on a date other than the first or last day of the tax year, the debtor will potentially owe some taxes on income earned before bankruptcy and some taxes on income earned after bankruptcy. For example, suppose that a debtor files a bankruptcy petition on November 1, 2005, and owes $\$ 12,000$ in taxes for the entire 2005 calendar year. Suppose also that the income upon which the taxes were imposed was earned evenly during the year. Eleven months of the tax liability was incurred on prepetition income, and one month of the tax liability was incurred on post-petition income. How will the government's claims for the unpaid tax liability be treated in bankruptcy?

The answer to this question was surprisingly complex and confusing prior to the new Bankruptcy Abuse, Prevention and Consumer Protection Act of $2005^{2}$ (the "2005 Act"), ${ }^{3}$ with courts reaching different results depending on whether the debtor was an individual or a corporation, and whether the debtor filed for a liquidation under Chapter 7 of the Bankruptcy Code, or sought to reorganize under Chapters 11-13 of the Bankruptcy Code.

The 2005 Act made what appeared to be a minor change in the language of section 507(a)(8)(A) of the Bankruptcy Code - the words "for a taxable year ending on or before the date of the filing of the petition" were moved from subsection 507(a)(8)(A)(i) to the flush language in subsection 507(a)(8)(A). The Senate Committee Report makes no mention of the reason for moving the language. ${ }^{4}$ Indeed, the change appears to have gone un-noticed by bankruptcy law experts discussing the new statute. ${ }^{5}$ Yet, the change will impact virtually every debtor who files a bankruptcy petition, and may dramatically impair the government's ability to collect the taxes on prepetition income earned in the year of bankruptcy. In the example stated above, a strong argument can be made that the change in the statute should allow a debtor to convert what would have been an $\$ 11,000$ claim that would be entitled to priority over most other general unsecured claims and would be excepted from discharge, into an $\$ 11,000$ general unsecured claim that could be discharged without full payment. ${ }^{6}$

This article looks at the treatment of the government's claims for taxes incurred in the year of bankruptcy by analyzing the complex state of the law before the change made by the 2005 Act, and then considering how those rulings may impact the law after the 2005 Act goes into effect for cases filed on or after October 17, 2005 . $^{7}$

${ }^{2}$ S. 256, PUB. L. No. 109-8, 199 Stat. 23 (2005).

${ }^{3}$ See discussion infra beginning at page 19 .

${ }^{4}$ See Bankruptcy Abuse Prevention and Consumer Protection Act of 2005 Report by Committee on the Judiciary S. 256, H.R. 109-31 pt. 1 (April 8, 2005), reprinted on Lexis at 2005 Committee Reports, April 8, 2005.

${ }^{5}$ See, e.g. Alan N. Resnick and Henry J. Sommer, The Bankruptcy Abuse Prevention and Consumer Protection Act of 2005: A Section-by-Section Analysis, Collier Portable Pamphlet, 2005 Supplement, p. lviii to lxiii (Lexis 2005) (discussing bankruptcy tax provisions without mentioning import of statutory change).

${ }^{6}$ See discussion infra starting at note 277.

${ }^{7}$ See 2005 Act, $\S 1501$ (although some provisions of the 2005 Act go into effect immediately, most of the Act is effective 180 days after enactment. The law was enacted on April 20, 2005, and thus goes into effect on October 17, 2005.) 


\section{The RELATIONSHIP BETWEEN PRIORITY AND DisCHARGEABILITY.}

One of the fundamental purposes of bankruptcy is to provide an individual debtor with a fresh start. Bankruptcy provides a "fresh start" by creating a clear separation between the debtor's prepetition assets and liabilities and the debtor's post-petition assets and liabilities. Upon filing bankruptcy, a new entity known as the bankruptcy estate is created. ${ }^{8}$ The bankruptcy estate becomes the owner of most of the debtor's assets as of the date of bankruptcy, ${ }^{9}$ and in turn the bankruptcy estate becomes liable for the debtor's debts existing as of the date of bankruptcy. ${ }^{10}$ In a Chapter 7 case, this new bankruptcy estate is administered by an independent trustee, ${ }^{11}$ whose job it is to sell off the debtor's assets and to distribute the proceeds to creditors in accordance with the rules of priority. ${ }^{12}$ In the usual Chapter 7 case, an individual debtor's personal liability for most ${ }^{13}$ prepetition claims is discharged. ${ }^{14}$ The debtor thus receives a "fresh start" by being allowed to earn money after the filing of the bankruptcy petition without subjecting those earnings to the claims of most prepetition creditors.

Certain claims against the bankruptcy estate are entitled to "priority" 15 under the Bankruptcy Code. Priority claims must be paid in full from the proceeds generated from the sale of the bankruptcy estate's property before lower priority and non-priority claims receive any distribution. ${ }^{16}$ Priority only directly impacts the rights of creditors vis à vis each other to receive distributions from the bankruptcy estate.

The Bankruptcy Code contains two separate priority provisions for income tax claims. First, the bankruptcy estate's post-petition income tax liabilities are entitled to a first priority (or, under the 2005 Act, a second priority ${ }^{17}$ ) as administrative expenses. ${ }^{18}$ As a general matter, administrative expense priority is given to creditors who render value to the estate after the bankruptcy petition is filed. ${ }^{19}$ However, the Bankruptcy Code

${ }^{8}$ See 11 U.S.C. $\S 541$.

${ }^{9} \mathrm{Id}$.

${ }^{10}$ See 11 U.S.C. $\S \S 101(5)$ (definition of "claim"), 502(b) (allowance of claims against the estate).

${ }^{11}$ See 11 U.S.C. $\S \S 701-704$.

1211 U.S.C. $\S \S 704(a)(1)$ ("trustee shall . . collect and reduce to money the property of the estate"), 726

(distribution of property of the estate to pay claims).

${ }^{13}$ Some prepetition claims are not discharged. See discussion infra beginning at note 40 .

${ }^{14} 11$ U.S.C. $\S \S 727$ (general rule for court to grant discharge), 524(a)(2) (discharge operates as an injunction against any act to collect a discharged debt).

${ }^{15}$ See 11 U.S.C. $\$ 507$.

${ }^{16} 11$ U.S.C. $\S 726(a)(1)$ ("property of the estate shall be distributed - (1) first, in payment of claims of the kind specified in, and in the order specified in, section 507 of this title.")

${ }^{17}$ Prior to the 2005 Act, administrative claims were entitled to a first priority. See 11 U.S.C. § 507(a)(1) (repealed 2005). However, the 2005 Act moved administrative clams to second priority behind spousal and child support obligations. See 11 U.S.C. § 507(a)(1), (a)(2) (2005).

${ }_{18} 11$ U.S.C. $\S \S 503$ (defining "administrative claims), 5077 (a)(1) (repealed 2005) (administrative claims subject to first priority), 507(a)(2) (2005) (administrative claims subject to second priority).

${ }^{19}$ Under the original Bankruptcy Code, a creditor received an administrative claim for rendering value to the estate. See 11 U.S.C. § 503(b)(1) (repealed 2005); Charles Jordan Tabb, THE LAW OF BANKRUPTCY, § 7.9, p. 504 (Foundation Press, 1997) ("Administrative expenses should be allowed to the extent that they will benefit the general creditors and the estate.... The fundamental prerequisites for most administrative expenses therefore are (1) that the claim be incurred post-petition in a transaction with the estate, and (2) that the claim benefit the estate"). 
grants administrative expense priority to any tax claim incurred by the estate, ${ }^{20}$ regardless of whether the estate received a benefit, ${ }^{21}$ as long as the claim is not subject to eighth priority. $^{22}$

Second, under very complex rules that incorporate applicable non-bankruptcy law and other provisions of the Bankruptcy Code, certain prepetition claims for income taxes are entitled to an eighth priority. ${ }^{23}$ Tax claims entitled to eighth priority are excluded from being treated as first priority administrative expenses. ${ }^{24}$ It is therefore necessary to first determine whether the tax claims in issue are entitled to eighth priority, and if not to then to determine whether the tax claims are entitled to first priority.

The priority rules are complicated by the cleavage between an individual debtor and the bankruptcy estate. When an individual debtor files under Chapter $7,{ }^{25}$ two separate taxpayers are created - the post-petition debtor and the bankruptcy estate. ${ }^{26}$ Because of the fresh start, the post-petition debtor's earnings are freed from the claims of most prepetition creditors by the discharge. ${ }^{27}$ The debtor, not the estate, is solely responsible for taxes on the debtor's post-petition earnings. ${ }^{28}$ Similarly, the estate may have post-petition earnings on the property of the estate, and those taxes are borne solely by the estate. ${ }^{29}$ The individual debtor is not personally liable for taxes on the estate's earnings. ${ }^{30}$

\footnotetext{
${ }^{20}$ The statute says that post-petition taxes entitled to eighth priority under section 507(a)(8) are not entitled to first priority as administrative expenses. 11 U.S.C. § 503(b). As is discussed below, a superficial reading of section 507(a)(8) would appear to cover all post-petition taxes. See discussion infra beginning at at note 135 . However, the courts have correctly held that section 507(a)(8) only applies to prepetition tax claims and not to post-petition tax claims. See infra at note 136. So why the reference to section 507(a)(8) in section 503(b)? How could a prepetition tax claim constitute an obligation of the estate, when the estate did not even exist prepetition to incur the tax debts? The answer to the riddle is that the government's claim for the prepetition portion of taxes in the year of bankruptcy technically arises at the end of the tax year. See discussion infra at notes 155 and 210. Prior to the 2005 Act, section 502(i) of the Bankruptcy Code was intended to treat the prepetition portion of taxes for the year of bankruptcy as if it were a prepetition claim even if it were deemed to arise post-petition. See discussion infra at note 232. The claim would be entitled to eighth priority under section 507(a)(8)(A)(iii) of the Bankruptcy Code, and would not be treated as a first priority administrative expenses. 11 U.S.C. $§ 503(\mathrm{~b})(1)(\mathrm{B})$.

However, under the change made by the 2005 Act, the prepetition taxes incurred in the year of bankruptcy will no longer be entitled to eighth priority (except where an individual debtor makes a splityear election, or possibly files on the last day of the tax year). See 11 U.S.C. § 507(a)(8) (flush language) (2005). Section 502(i) will no longer apply to these taxes, because they no longer fall under section 507(a)(8). How these prepetition taxes will be treated under the 2005 Act is unclear. See discussion infra beginning at page 41 ..

${ }^{21} 11$ U.S.C. $\S 503$ (b). In addition, fines, penalties and reductions in credit relating to administrative taxes are also entitled to administrative priority. 11 U.S.C. $§ 503(\mathrm{c})$.

${ }^{22} 11$ U.S.C. $\S 503(\mathrm{~b})(1)(\mathrm{B})$.

${ }^{23}$ See discussion infra beginning at note 54 .

${ }^{24} 11$ U.S.C. $\S 503(\mathrm{~b})(1)(\mathrm{B})$.

${ }^{25}$ For simplicity, I have assumed that the debtor is voluntarily filing a bankruptcy case. The same rules apply in an involuntary case if the bankruptcy court grants relief under Chapter 7. See 11 U.S.C. § 303(h).

${ }^{26}$ See 11 U.S.C. $\$ 541$.

${ }^{27} 11$ U.S.C. $\$ 727(b)$.

${ }^{28} 26$ U.S.C. $\S 1398(\mathrm{e})(2)$. All references hereafter to 26 U.S.C. shall be to the "Internal Revenue Code" or "I.R.C."

${ }^{29}$ See I.R.C. § 1398(e)(1).

${ }^{30}$ I.R.C. $\S 1398(\mathrm{e})(2)$.
} 
To constitute an administrative expense subject to first priority, the tax liability must be "incurred by the estate." 31 Tax liabilities of the debtor that were not "incurred by the estate" 32 are not entitled to priority as administrative expenses, ${ }^{33}$ and may not be claims against the estate at all. ${ }^{34}$ This cleavage between the post-petition debtor and the post-petition estate does not apply to entity taxpayers because they do not have a separate existence from the estate. ${ }^{35}$

The proper analysis of year-of-bankruptcy claims depends on whether the taxes on prepetition income are treated as prepetition taxes, ${ }^{36}$ or whether the taxes on prepetition income are treated as post-petition taxes that are deemed to arise at the end of the year. ${ }^{37}$ The courts have taken inconsistent positions on this fundamental question depending on whether the taxpayer is an individual or a corporation. ${ }^{38}$ These inconsistent positions are about to be magnified by a change in the 2005 Act, which eliminates the possibility of relying on the eighth priority rules to avoid treating the taxes on prepetition income either as first priority administrative expenses or as general unsecured claims. ${ }^{39}$

A separate question from priority is whether the government's claims are excepted from discharge. ${ }^{40}$ Claims excepted from discharge remain collectible from the debtor's post-bankruptcy earnings. There are several different ways in which tax claims may be excepted from discharge. First, all tax claims entitled to eighth priority are excepted from discharge. ${ }^{41}$ Second, if the debtor committed certain types of wrongful conduct, the tax claims arising therefrom are excepted from discharge even though they may not be entitled to priority. ${ }^{42}$ Finally, claims that did not exist prepetition are not

\footnotetext{
31 11 U.S.C. $\S 503(\mathrm{~b})(1)(\mathrm{B})$.

${ }^{32}$ The Internal Revenue Code provides that the bankruptcy estate and not the debtor is to be liable for taxes on income "received or accrued" post-petition to which the estate is entitled. I.R.C. $§ 1398(e)(1)$. Therefore, the allocation issue should properly focus on whether the income upon which the taxes are imposed belongs to the estate (in which case the government has a claim against the estate and not the debtor) or to the debtor individually (in which case the government's sole claim is against the debtor). ${ }^{33} I d$.

${ }^{34}$ See discussion infra beginning at note 192.

35 See I.R.C. $\S 1399$.

${ }^{36}$ This is what the courts have done with corporate taxes, relying on section 507(a)(8)(A)(iii) to treat the pre-petition portion of year-of-bankruptcy taxes as eighth priority taxes, which are excepted from discharge under 523(a)(1)(A). See discussion infra beginning at note 151. The Internal Revenue Service has consistently disputed this treatment, seeking to obtain first priority administrative expense treatment for taxes on prepetition income. See infra at note 178.

${ }^{37}$ This is what the courts have done with individual taxpayers who do not make the split-year election. See discussion infra beginning at note 192.

${ }^{38}$ Supra notes 36 and 37.

${ }^{39}$ See discussion infra beginning at page 41 .

${ }^{40}$ See 11 U.S.C. $\$ 523$.

4111 U.S.C. $\S 523(\mathrm{a})(1)$.

42 The debtor does not receive a discharge if the debtor failed to file a required tax return, filed a required tax return late and within two years of bankruptcy, filed a fraudulent return, or willfully attempted to evade or defeat the tax in any manner. 11 U.S.C. $\S \S 523(\mathrm{a})(1)(\mathrm{B})-(\mathrm{C})$. Claims for taxes that are excepted from discharge on one of these grounds are not entitled to eighth priority, apparently even if there is an independent basis for eighth priority. See 11 U.S.C. $\S 507(a)(8)(A)(i i i)$. With respect to year-ofbankruptcy taxes, only the tax fraud provisions could apply because the return would not be due at the time of bankruptcy, and it would be unusual for tax fraud to occur before the return is due. Therefore, these specific exceptions to discharge would only rarely be relevant to year-of-bankruptcy taxes.
} 
covered by the discharge, as the discharge only applies to prepetition claims. ${ }^{43}$ The discharge therefore does not apply to most administrative expenses, because the expenses were incurred post-petition. However, unlike most administrative expenses, tax claims "incurred by the estate" and not entitled to eighth priority are treated as administrative expenses ${ }^{44}$ irrespective of when the claims were incurred or accrued.

Unlike eighth priority claims which are always excepted from discharge, ${ }^{45}$ tax claims that are entitled to first priority as administrative expenses may be dischargeable, as there is no blanket discharge exception from discharge for first priority administrative expenses. ${ }^{46}$ If there are insufficient assets in the estate to pay first priority administrative expenses, and the discharge covered the administrative expenses, the government would not be able to collect the unpaid balance if the post-petition obligation is subject to discharge. However, the Chapter 7 discharge only applies to prepetition claims, ${ }^{47}$ so post-petition administrative expenses would generally not be discharged in a Chapter 7 case. However, prepetition administrative expenses - if there is such a thing ${ }^{48}$ - would be subject to discharge in Chapter 7. Moreover, the Chapter 11 discharge applies to preconfirmation obligations, and thus covers post-petition pre-confirmation administrative expenses which are not paid as part under the plan of reorganization. ${ }^{49}$

Prepetition non-priority tax claims incurred in the year of bankruptcy would generally be dischargeable. ${ }^{50}$ General unsecured creditors are thus at significant risk of receiving less than full payment in bankruptcy cases.

The proper characterization of the claim is therefore essential to determine how the claim will be treated in the distribution of the bankruptcy estate, and whether the claim will be collectible from the debtor's post-petition assets and earnings. The complex interplay between the priority and dischargeability rules creates many confusing and complex issues that are considered below.

\section{PRIORITY FOR INCOME TAX CLAIMS IN THE YEAR OF BANKRUPTCY.}

There are two basic ways in which income tax claims may be entitled to priority under the Bankruptcy Code: (1) as first priority administrative expenses, ${ }^{51}$ and (2) as

\footnotetext{
${ }^{43}$ See 11 U.S.C. $§ 727$ (b) ("a discharge ... discharges the debtor from all debts that arose before the date of the order for relief").

${ }^{44} 11$ U.S.C. $\S 503(\mathrm{~b})(1)(\mathrm{B})$.

${ }^{45} 11$ U.S.C. $\$ 523(\mathrm{a})(1)(\mathrm{A})$.

${ }^{46}$ See 11 U.S.C. $\$ 523$ (note the absence of provision excepting administrative priority claims from discharge).

${ }^{47} 11$ U.S.C. $\S 727$ (b) (discharge of claims "that arose before the date of the order for relief.")

${ }^{48}$ See discussion infra beginning at note 268 as to whether the government's claim for the prepetition portion of taxes incurred in the year of bankruptcy under the 2005 Act will be entitled to first priority as an administrative expense. The issue is whether the taxes on prepetition income are "incurred by the estate" within the meaning of 11 U.S.C. § 503(b)(1)(B)(i).

${ }^{49}$ See 11 U.S.C. $\$ 1141$ (b)(1)(A). However, confirmation of the plan requires first priority administrative expenses to be paid in cash in full on the effective date. 11 U.S.C. $§ 1129(a)(9)(A)$. Therefore only administrative expenses which are not properly claimed as part of the plan would be subject to discharge.

${ }^{50}$ The claim would be excepted from discharge only if the debtor made a "willful attempt to evade or defeat taxes" within the meaning of 11 U.S.C. section 523(a)(1)(C).

${ }^{51} 11$ U.S.C. $\S \S 503(\mathrm{~b})(1)(\mathrm{B}) ; 507(\mathrm{a})(1)$.
} 
eighth priority claims. ${ }^{52}$ Because income taxes entitled to eighth priority are not entitled to first priority as administrative expenses,${ }^{53}$ one must first determine whether the government's claim for taxes is entitled to eighth priority before analyzing whether the government's claim is entitled to treatment as a first priority administrative expense.

The Bankruptcy Code grants an eighth priority under section 507(a)(8) to the government's income tax claims if they fall within any one ${ }^{54}$ of the following three rules: (1) the lookback rule, ${ }^{55}$ (2) the 240 day assessment rule, ${ }^{56}$ and (3) the post-petition assessability rule. $^{57}$ Each of these three rules is highly complex, and each is considered in order.

\section{The Lookback Rule.}

The lookback rule gives a priority to taxes for which a return was last due within the three year period before the filing of the bankruptcy petition. ${ }^{58}$ The due date of the return, not the date that the taxes were incurred or the year for which the taxes were due, is the key date for determining whether the taxes are non-dischargeable under the lookback rule. ${ }^{59}$

While the lookback rule is written mechanically, the Supreme Court recently held that the three year lookback period is, in essence, a statute of limitations, albeit one that involves priority rather than enforceability of a claim, and can thus be equitably tolled when the government is prevented from assessing taxes as a result of an earlier bankruptcy case. ${ }^{60}$

The 2005 Act codifies and expands the Supreme Court's determination that the lookback period is tolled during a prior bankruptcy case. All of the statutory periods during which a priority is granted for governmental claims, including the lookback period, are suspended during the stay in a prior case plus 90 days. ${ }^{61}$ In addition, the periods are suspended for any period, plus 90 days, during which the government is prohibited from collecting the tax as a result of a debtor's request for hearing or appeal. ${ }^{62}$

Even before the 2005 Act, the lookback rule contained language making it clear that the rule applied only to tax years "ending on or before" the petition date. ${ }^{63}$ On its

\footnotetext{
5211 U.S.C. $\S 507(\mathrm{a})(8)$.

5311 U.S.C. $\S 503(\mathrm{~b})(1)(\mathrm{B})$ (granting priority to a tax incurred by the estate "except a tax of a kind specified in section 507(a)(8)").

${ }^{54}$ The three provisions are written in the alternative (see the use of "or" in 11 U.S.C. $\$ 507(a)(8)(A)(i i)$ ). See also In re Vitaliano, 178 B.R. 205, 208 (B.A.P. 9th Cir. 1995); In re Etheridge, 91 B.R. 842,845 (Bankr. C.D. Ill. 1988) (holding that priority is to be granted if the taxes fall within any one of the three rules); In re Easton, 59 B.R. 714, $716-17$ (Bankr. C.D. Ill. 1986); In re Coleman American Moving Services, Inc., 20 B.R. 267, 269 (Bankr. D. Kan. 1981).

${ }^{55} 11$ U.S.C. $\S 507(\mathrm{a})(8)(\mathrm{A})(\mathrm{i})$.

${ }^{56} 11$ U.S.C. $\$ 507(\mathrm{a})(8)(\mathrm{A})(\mathrm{ii})$

57 11 U.S.C. $\$ 507(\mathrm{a})(8)(\mathrm{A})(\mathrm{iii})$.

${ }^{58} 11$ U.S.C. $\$ 507(\mathrm{a})(8)($ A.

${ }^{59} I d$.

${ }^{60}$ In re Young, 535 U.S. 43, 47 (2002).

${ }^{61}$ See 11 U.S.C. $§ 507(a)(8)$ (flush language) (2005).

${ }^{62} \mathrm{Id}$.

${ }^{63}$ Prior to the 2005 Act, the lookback rule granted priority for income taxes "for a taxable year ending on or before the date of the filing of the petition for which a return, if required, is last due, including extensions, after three years before the date of the filing of the petition." 11 U.S.C. $\S 507(a)(8)(A)(i)$.
} 
face, the lookback rule appeared not to apply to year-of-bankruptcy taxes incurred by calendar year taxpayers who filed bankruptcy on any date other than December 31, because the taxpayer's calendar tax year would not have ended "on or before" the petition date. Similarly, for fiscal year taxpayers, the lookback rule appeared not to apply to petitions filed on any date other than the last day of the taxpayer's fiscal year. However, this appearance is false, because of the split-year election.

The Internal Revenue Code allows an individual debtor in a Chapter 7 or Chapter 11 case $^{64}$ to elect to split the tax year in which a bankruptcy petition is filed into two separate tax years - the first one ending on the date that the bankruptcy petition was filed. ${ }^{65}$ If the debtor makes the split-year election, the taxes owing for the pre-petition partial year of bankruptcy would fall under the language of the lookback rule, because the partial tax year would have ended "on or before" the petition date.

Because only individuals in cases under Chapters 7 or 11 may make the split-year election, ${ }^{66}$ and because it is optional, ${ }^{67}$ taxes incurred in the year of bankruptcy by entity taxpayers, such as corporations, by individuals in Chapter 12 and 13 cases, and by individuals who do not make the split-year election ${ }^{68}$ will not be entitled to priority under the lookback rule, unless the debtor happens to file bankruptcy on the last day of the debtor's tax year.

\section{The 240 Day Rule.}

All taxes which are "assessed" within 240 days prior to bankruptcy are entitled to priority. ${ }^{69}$ Taxes assessed more than 240 days before bankruptcy may also be entitled to

\footnotetext{
${ }^{64}$ Debtors in Chapter 12 and 13 cases are not eligible to make the split-year election. This is because there is no cleavage between the debtor's and the estate's post-petition income in Chapter 12 and 13 cases, because the debtor is required to use its "projected disposable income" for three or five years to fund the plan. See 11 U.S.C. $\S \S 1225(\mathrm{~b})(1), 1325(\mathrm{~b})(1)(B)$. Therefore, individuals in Chapter 12 and 13 cases are treated much like corporations - unable to make a split-year election.

Under the 2005 Act, individual Chapter 11 debtors are also treated much like Chapter 12 and 13 debtors, in that they are required to use their projected disposable post-petition income for five years to fund the plan. See 11 U.S.C. § 1129(a)(15). Congress did not consider the effect of the 2005 Act changes on the right to make a split-year election. It would appear under the existing statute that this post-petition income which the debtor is required to use to fund the plan would be taxable to the estate and not to the debtor, since the income is subject to use by the estate. See I.R.C. $\S \S 1398(e)(1),(e)(2)$.

${ }^{65}$ I.R.C. $\$ 1398(d)(2)(A)(i)$.

${ }^{66}$ I.R.C. $\$ 1398$ (a) (section applies "to any case . . . in which the debtor is an individual.")

${ }^{67}$ See I.R.C. § 1398(d)(2)(A) ("the debtor . . . may elect"); see also In re Prativadi, 281 B.R. 816, 819 (Bankr. W.D.N.Y. 2002); In re Haedo, 211 B.R. 149, 152 (Bankr. S.D.N.Y. 1997); In re Johnson, 190 B.R. 724, 726-27 (Bankr. Mass. 1995); In re Mirman, 98 B.R. 742, 744-745 (Bankr. E.D. Va. 1989); In re

Turboff, 93 B.R. 523, 525 (Bankr. S.D. Tex. 1988). The election must be made prior to the due date for the return, and the election once made is irrevocable. I.R.C. § 1398(d)(2)(D). For individuals, the due date for the return is "the 15th day of the fourth month following the close of the fiscal year." I.R.C. § 6072(a). For corporations, the return is due on "the 15 th day of the third month" following the petition date. I.R.C. $\S$ 6072(b).

${ }^{68} 11$ U.S.C. $\S 507(\mathrm{a})(8)(\mathrm{A})(\mathrm{i})$.

${ }^{69} 11$ U.S.C. § 507(a)(8)(A)(ii). A longer period of time applies if the taxpayer made an offer in compromise within 240 days after an assessment is made. The statute extends the 240 day period by 30 days plus the time that the offer in compromise was pending, presumably because the Secretary would not attempt to collect the tax while the offer was pending. See 11 U.S.C. § 507(a)(8)(A)(ii).
} 
priority if there was an offer in compromise in effect after assessment, ${ }^{70}$ if collection during the 240 day period was stayed by a prior bankruptcy case, ${ }^{71}$ or possibly if the government was prohibited from collecting the tax by applicable non-bankruptcy law because of a request for hearing or appeal filed by the debtor. ${ }^{72}$

Taxes may only be assessed either when a tax return is filed showing an amount due, ${ }^{73}$ or after a return is due if the government follows the procedures for making a socalled deficiency assessment. ${ }^{74}$

Since a taxpayer cannot file a return until after the end of the tax year, ${ }^{75}$ and since a return is not due until after the end of the taxable year, ${ }^{76}$ an assessment cannot be made

\footnotetext{
${ }^{70}$ The statutory language in effect prior to the 2005 Act was confusing, but the courts interpreted the language to allow a lengthy extension of the 240 day period if the offer in compromise was entered into within 240 days after assessment. See, e.g. In re Romagnolo, 269 B.R. 63, 66 ("Accordingly, when an offer in compromise is submitted within 240 days of assessment, the 240 day period is extended 30 days plus any time during which the offer-in-compromise was pending.") ; Accord In re Mulcahy, 260 B.R. 612, 617 (Bankr. Mass. 2001) (taxes assessed 317 days before bankruptcy entitled to priority because offer in compromise pending for 210 days and any assessment within 480 days of bankruptcy $(240+210+30)$ would have been entitled to priority); In re Chelena, No. 96-66521, 1997 Bankr. LEXIS 1720, *2-3; 80 A.F.T.R.2d (RIA) 7562 (Bankr. N.D. Ga. 1997) (adding 1,049 days to the statutory 240 day period because of a longstanding offer in compromise). Under the 2005 Act, the 240 day period is extended by the number of days during the 240 day period that an offer in compromise was pending or in effect, plus 30 days. 11 U.S.C. $\S 507(\mathrm{a})(8)(\mathrm{A})(\mathrm{ii})(\mathrm{I})$ (2005). The changes made by the 2005 Act set the maximum period at 510 days if the offer in compromise was in effect during the entire 240 day period preceding bankruptcy. ${ }^{71}$ The Supreme Court held, in dicta, that the 240 day period would be tolled during the period in a prior bankruptcy case that the government was stayed from collecting the taxes. In re Young, 535 U.S. at 44. The 2005 Act codifies and extends the holding in Young. Under the 2005 Act, the 240 day period is extended for 90 days plus the period during which the government was prevented by law from collecting the taxes, if the prohibition occurred in the debtor's prior bankruptcy case. 11 U.S.C. § 507(a)(8) (flush language) (2005).

${ }^{72}$ The 2005 Act provides that all tax priority periods are extended during the period that the government is prohibited by applicable non-bankruptcy law from pursuing collection because the debtor is requesting a hearing or filing an appeal. This language was likely drafted to protect the government from losing priority status when taxpayers file appeals or court challenges in connection with collection due process cases brought under I.R.C. sections 6320 and 6330.

${ }^{73}$ I.R.C. $\S 6201(\mathrm{a})(1)$ ("The Secretary shall assess all taxes determined by the taxpayer or by the Secretary as to which returns or lists are made under this title."). This is known as a "self assessment" because the taxpayer has permitted an assessment by admitting on the return the taxpayer's obligation to pay the taxes shown. In addition, the government may assess taxes even though not shown on a return as owing where the taxpayer has made a simple computational error. See I.R.C. § 6213(b) (Secretary may assess taxes arising out of mathematical or clerical errors without notice of deficiency, but taxpayer has right to request prompt abatement).

${ }^{74}$ See I.R.C. $\S \S 6213(\mathrm{a})$ (““ $[\mathrm{N}] \mathrm{o}$ assessment of a deficiency ... .and no levy or proceeding in court for its collection shall be made . . until the expiration of such 90 day period . . . nor, if a petition has been filed with the Tax Court, until the decision of the Tax Court has become final"), 6211(a) ("[T]he term 'deficiency' means the amount by which the tax imposed ... exceeds the excess of - (1) the sum of (A) the amount shown as the tax by the taxpayer upon his return, if a return was made by the taxpayer and an amount was shown as the tax by the taxpayer thereon, plus (B) the amounts previously assessed (or collected without assessment) as a deficiency, over (2) the amount of rebates, as defined in subsection (b)(2), made.")

${ }^{75}$ The Tax Code does not actually say this - it merely says when is the last day for filing a return. See I.R.C. $\S 6072(a)$. However, a taxpayer could not compute the amount of tax due until the end of the tax year, and therefore could not file a return before the end of the year. See I.R.C. § 6012(a) (returns must be filed by "individuals having for the taxable year income").

${ }^{76}$ I.R.C. $\S 6072(a)$ (Calendar year returns due April 15 of following year).
} 
until after the end of the taxpayer's calendar or fiscal year. Therefore, the 240 day rule cannot apply to taxes incurred in the year of bankruptcy, because the taxes could not have been assessed prior to the petition date since the tax year had not ended before the petition date. $^{77}$

\section{The Post-Petition Assessability Rule before the 2005 Act.}

For cases filed prior to the effective date of the 2005 Act, ${ }^{78}$ the post-petition assessability rule granted a priority to taxes that were not assessed before, but were assessable under applicable non-bankruptcy law after, the date that the bankruptcy petition was filed, unless the taxes were "of a kind specified in section 523(a)(1)(B) or 523(a)(1)(C)." "79 Taxes incurred for the year of bankruptcy could not be assessed prepetition, ${ }^{80}$ and were always assessable post-petition. ${ }^{81}$ Thus, all taxes in the year that bankruptcy was filed (and indeed all taxes arising for future post-bankruptcy years) would appear to fit within the technical language of the post-petition assessability rule, unless the taxes were "of a kind" specified in the referenced provisions of section 523.

\section{A. Taxes "of a kind specified in section 523(a)1)(B) and (C)."}

The first interpretative problem with the statute is determining what taxes are excluded from eighth priority because they are "of a kind" specified in section 523(a)(1)(B) or (C). Section 523 contains a list of claims excepted from an individual debtor's discharge. ${ }^{82} \mathrm{~A}$ debtor remains personally liable to pay claims excepted from discharge even though the debtor receives a general discharge under the Bankruptcy Code. ${ }^{83}$ The referenced subsections in Bankruptcy Code section 523 cover taxes excepted from discharge because the debtor (1) failed to file a required tax return, (2) filed a required tax return late and within two years of bankruptcy, (3) filed a false return, or (4) willfully attempted to evade or defeat taxes. ${ }^{84}$ Thus, taxes excepted from discharge for one of these reasons are not entitled to eighth priority under section 507(a)(8), even though the taxes are assessable post-petition. Presumably, Congress did not want a taxpayer to get the benefit of having the non-dischargeable claim reduced by priority distributions from the

\footnotetext{
${ }^{77}$ Even if the split-year election is made, the partial tax year will not have ended before bankruptcy, and there will be no way for the government to make an assessment prepetition.

${ }^{78}$ Most provisions of the 2005 Act are effective on October 17, 2005. See supra note 7.

${ }^{79} \mathrm{Id}$.

${ }^{80}$ See supra notes $75-76$.

${ }^{81}$ The government has at least three years after the date the return for the taxes is due to assess taxes. See I.R.C. $\S 6501(a)$. Note that if a return is filed before the due date, it is treated as filed on the due date for purposes of determining the limitations period. I.R.C. $\S 6501(\mathrm{~b})(1)$.

82 11 U.S.C. $\$ 523(\mathrm{a})$ ("[a] discharge ... does not discharge an individual debtor from any debt").

${ }^{83}$ According to section 523(c) of the Bankruptcy Code, certain of the debts excepted from discharge are automatically excepted from discharge, while others are excepted from discharge only if the creditor timely obtains an order from the court determining that the debts are excepted. The tax debts listed in section 523(a) of the Bankruptcy Code are automatically excepted from discharge.

${ }^{84}$ See 11 U.S.C. $\$ \S 507(a)(8)(A)($ iii) (assessable post-petition other than 523(a)(1)(B), 523(a)(1)(C)), $523(\mathrm{a})(1)(\mathrm{B})$ (non-filed or late filed returns), 523(a)(1)(C) (willful attempt to evade or defeat taxes).
} 
bankruptcy estate where the taxes are assessable post-petition solely because of the debtor's misconduct. ${ }^{85}$

\section{i. $\quad$ Late Returns Filed More than Two but Fewer than Three Years Before Bankruptcy.}

The reference to taxes "of a kind" specified in the referenced subsections of section 523 causes a number of interpretative problems. First, Congress made an error in the drafting of the late-filed return language of section 523(a)(1)(A), which potentially causes taxes which Congress intended to be dischargeable to be both entitled to priority and excepted from discharge. Congress provided that taxes covered by a late return filed more than two years before bankruptcy would not be excepted from discharge (i.e. would be dischargeable). ${ }^{86}$ Congress likely did not want to punish taxpayers for filing late returns - by making the tax claim non-dischargeable - if the government had at least two full years before bankruptcy to collect the taxes. ${ }^{87}$

The law works as intended with respect to taxes covered by late returns filed fewer than two years before bankruptcy - the taxes would be excepted from discharge. ${ }^{88}$

\footnotetext{
${ }^{85}$ The statutory cross-reference to section 523(a)(1)(B) and (C) is much broader than it should be. For example, if there is an independent basis for allowing taxes to be assessed post-petition (other than the fact that the debtor failed to file a return, for example), why should the fact that the debtor failed to file a return preclude priority? Congress likely meant that tax claims are not to be given priority solely because they are assessable post-petition due to the fact that the debtor failed to file a return, filed a false return, etc. If there is an independent basis upon which the taxes can be assessed post-petition, the government should not lose priority because one of the grounds in section 523(a)(1)(B) or (C) provides an alternative basis for making the assessment post-petition. This could be relevant to year-of-bankruptcy taxes if the prepetition portion of the taxes were entitled to eighth priority. For example, the courts have held that the prepetition portion of a corporation's year of bankruptcy taxes is entitled to priority under section 507(a)(8)(A)(iii) - at least before the 2005 Act. See discussion infra beginning at note 152. Under the statute, however, the government would lose priority if the debtor happened to willfully attempt to evade or defeat taxes. See 11 U.S.C. $\S 507(a)(8)(A)($ iii) (reference to "other than a tax of a kind specified in . . 523(a)(1)(C)"). Surely, this result was not intended.

${ }^{86} 11$ U.S.C. § 523(a)(1)(B)(ii) (general discharge does not discharge individual debtor from a tax for which a return "was filed after the date on which such return was last due under applicable law or under any extension, and after two years before the date of the filing of the petition.") (repealed 2005). Minor changes were made in the 2005 Act to cover situations in which a taxpayer is required to file or give a report or a notice rather than a tax return. See 11 U.S.C. § 523(a)(1)(B)(ii) (2005).

${ }^{87}$ The report of the Commission on Bankruptcy Laws of the United States, upon which the Bankruptcy Reform Act of 1978 was based, originally provided that taxes covered by a late return filed within three years of bankruptcy would be non-dischargeable. Report of the Commission on the Bankruptcy Laws of the United States, § 523(a)(1)(B)(ii), H.R. Doc. No. 137, 93rd Cong., 1st Sess. (1973), reprinted in App. B(c) Collier on Bankruptcy - 15th Edition Revised, App. Pt. 4 Bankruptcy Reform Act of 1978. The three year period proposed by the Bankruptcy Commission would have matched the federal statute of limitations period. However, the House version, H.R. 8200, 95th Cong., 1st Sess. (1977), changed the period from three years to one year. Id. The Senate version, S.2266, 95th Cong., 2d Sess., as reported by the Senate Judiciary Committee and the Senate Finance Committee (1978), adopted the three year period recommended by the Commission. The conference committee (apparently in a compromise) changed the period to two years. Id.

${ }^{88}$ Since the return was filed late and after two years before the date of the filing of the petition, the taxes would be excepted from discharge. 11 U.S.C. § 523(a)(1)(A)(i). In addition, because the taxes are excepted from discharge under section 523(a), the taxes would not be entitled to priority under the post-
} 
Similarly, the law generally ${ }^{89}$ works as intended with respect to most taxes covered by a late return filed more than three years before bankruptcy - the taxes would not be excepted from discharge because of the late filing of the return (and, unless another independent exception to discharge applied, would be dischargeable).$^{90}$

The problem arises with respect to taxes covered by a late return that is filed more than two but fewer than three years before bankruptcy, because of the interplay between the two-year rule in Section 523(a)(1)(B) and the post-petition assessability rule coupled with the normal three-year period of limitations for assessment of a deficiency contained in the Internal Revenue Code. ${ }^{91}$ Taxes covered by a late return filed more than two but fewer than three years before bankruptcy would not be excepted from discharge under section 523(a)(1)(B), because Congress intended to allow discharge when the government had a full two years before bankruptcy to attempt to collect the taxes. However, the taxes would still be assessable post-petition under the three year statute of limitations contained in the Internal Revenue Code, which begins to run only when the tax return is filed. ${ }^{92}$ The taxes would thus be entitled to priority under a conventional reading of section 507(a)(8)(A)(iii) - because the taxes would be assessable post-petition under applicable non-bankruptcy law, and would not be excepted from discharge under sections 523(a)(1)(B) or (C). The Catch-22 is that all eighth priority taxes are non-

petition assessability rule. 11 U.S.C. $\S 507(a)(8)(A)(i i i)$. However, the taxes may be entitled to priority under the lookback rule or the 240 day rule. See discussion supra beginning at note 58 .

${ }^{89}$ There are a number of situations in which taxes can be assessed under applicable non-bankruptcy law more than three years after a return is filed. First, there is no statute of limitations on assessment if the taxpayer files a fraudulent return, or willfully attempts to defeat or evade taxes. I.R.C. §§6501(c)(1), 6501(c)(2)). In such cases, the taxes would be excepted from discharge under 11 U.S.C. § 523(a)(1)(C) anyway. Second, there is a six year statute of limitations if a return contains a "substantial omission of income." I.R.C. $§ 6501(\mathrm{e})(1)(\mathrm{A})$. A substantial omission is an amount exceeding $25 \%$ of the gross income reported. Id. Third, the assessment limitations period is tolled for the period plus 60 days during which the Secretary is prohibited from making an assessment after the Secretary mails to the taxpayer the required statutory notice of deficiency which is a prerequisite to assessment. I.R.C. $\S 6503(a)$. The Secretary is prohibited from making an assessment for the 90 day period following the mailing of the notice. I.R.C. $\S$ 6213(a). In addition, if the taxpayer files a petition with the Tax Court to re-determine the proposed deficiency during the 90 day period following the mailing of the statutory notice of deficiency, then the Secretary is stayed from assessing a deficiency until a Tax Court's re-determination becomes final. Id. Thus, the three year period can be greatly extended by a taxpayer challenging a proposed assessment in the Tax Court. Finally, the limitations period can be extended by agreement. I.R.C. § 6501(c)(4). In any of these situations, the taxes are assessable post-petition under applicable non-bankruptcy law for a reason other than the late filing of the return. Because the taxes are assessable post-petition for a reason other than the late-filing of the return, Congress may well have intended such taxes to be given priority and to be excepted from discharge even though the late return was filed more than two years before bankruptcy.

${ }^{90}$ As a general matter, if the late-filed return is filed more than three years before bankruptcy, the government would be barred from making an assessment on or after the petition date by the applicable three-year statute of limitations contained in the Tax Code, which begins to run upon the filing of the return. See I.R.C. § 6501(a). If the statute of limitations on collection expires before the bankruptcy petition is filed, the claim in bankruptcy would be disallowed in its entirety and would not be entitled to priority in bankruptcy. See 11 U.S.C. $§ \S 507(a)(8)(A)$ (only "allowed unsecured claims of governmental units" are given priority) (emphasis added); 502(a)(1) (claims that are unenforceable under applicable nonbankruptcy law are not "allowed.").

${ }^{91}$ The 3 year statute of limitations on assessment contained in the Internal Revenue Code begins to run only when a return is filed. See I.R.C. $\S 6501(a)$.

${ }_{92}$ I.R.C. $\S 6501$ (a) (government has at least three years from the time a return is filed to assess a deficiency). 
dischargeable under section 523(a)(1)(A). Thus, although Congress provided that taxes covered by a late return filed more than two years before bankruptcy would be dischargeable under section 523(a)(1)(B)(ii), the boomerang effect of not being excepted from discharge under section 523(a)(1)(B)(ii) is that the taxes are eligible for eighth priority treatment under the post-petition assessability rule of section 507(a)(8)(A)(iii), and in turn are excepted from discharge under 523(a)(1)(A). Congress surely did not intend by shortening the nondischargeability period for late-filed returns to two years to grant a priority and make nondischargeable taxes subject to late returns filed more than two but fewer than three years before bankruptcy. ${ }^{93}$ It appears that Congress simply made an error by shortening the period in section 523(a)(1)(B) without addressing the boomerang effect of section 507(a)(8)(A)(iii) and section 523(a)(1)(A).

The confusion created by Congress' snafu did not go unnoticed by litigants and the courts. In In re Doss, ${ }^{94}$ the debtors sought a determination that taxes owing on late returns filed more than two but fewer than three years before bankruptcy were excepted from discharge and not entitled to priority. ${ }^{95}$ The government argued that because the taxes were more than two years old (and thus not covered by section 523(a)(1)(B)), they were entitled to priority (and, because they were entitled to priority, the taxes were not dischargeable under section 523(a)(1)(A)). ${ }^{96}$

To carry out the intent of Congress, the Doss court held that the taxes were not entitled to priority and were dischargeable. However, the court's explanation of its decision only added to the confusion: "the clauses following the first comma [in $507(\mathrm{a})(8)(\mathrm{A})(\mathrm{iii})]$ modify and relate to the first clause." 97 This explanation is plainly wrong - it is clearly the phrase before the comma that limits the language after the comma. More importantly, the implications of the court's ruling were ambiguous. Indeed, some debtors argued on the basis of Doss that the post-petition assessability rule in section 507(a)(8)(A)(iii) only applied to late-filed returns. ${ }^{98}$

Using language almost as confusing as the Doss opinion itself, some courts sought to distinguish Doss by suggesting that the Doss court had merely ruled that the taxes were dischargeable, not that they were non-priority. ${ }^{99}$ In fact, however, the Doss

\footnotetext{
${ }^{93}$ Indeed, the legislative history suggests that Congress intended not to grant a priority to taxes due solely to the debtor's conduct in filing a return late, not filing a return at all, or committing tax fraud. According to the Senate Report: "The bankruptcy policy for this treatment is that it is not fair to penalize private creditors of the debtor by paying out of the "pot" of assets in the estate tax liabilities arising from the debtor's deliberate misconduct. On the other hand, the debtor should not be able to use bankruptcy to escape these kinds of taxes. Therefore, these taxes have no priority in payment from the estate but would survive as continuing debts of the case. (Not giving priority to a debt means that the creditor can still collect part or all of the debt from the estate, but the creditor must do so as general creditor, sharing pro rata with other general creditors)." S. REP. No. 95-1106 at 22 (1978).

${ }^{94}$ In re Doss, 42 B.R. 749, 750 (Bankr. E.D. Ark. 1984).

${ }^{95} \mathrm{Id}$. at 750.

${ }^{96} I d$. at $751-52$.

${ }^{97} I d$. at 754.

${ }^{98}$ See In re Wines, No. 91-0433, 1992 U.S. Dist. LEXIS 5574, *11, *23-24; Bankr. L. Rep. (CCH) $\uparrow 74,674$ (S.D. Fla. 1992).

${ }_{99}^{99}$ In re Longley, 66 B.R. 237, 241 (Bankr. N.D. Ohio 1986) ("[t]he Doss court held that Section 507(a)(6)(A) contained its own exclusions; namely, taxes of a kind specified in Section 523(a)(1)(B), and that merely because a tax was still "assessable" as of the date of the filing of the Title 11 petition did not mean that a tax excluded from the nondischargeability provision of Section 523(a)(1)(B)(ii) was, nonetheless, nondischargeable under Section 507(a)(6)(A)(iii).").
} 
opinion clearly stated that the taxes were not entitled to priority. ${ }^{100}$ Other courts have rejected the Doss court's analysis outright rather than trying to distinguish it. ${ }^{101}$ For example, the court in In re Torrente, rejected both the analysis and holding of Doss, ruling that the taxes covered by a late filed return, which was filed more than two but fewer than three years before bankruptcy, were entitled to priority under section $507(\mathrm{a})(8)(\mathrm{A})(\mathrm{iii})$, and were also nondischargeable under section 523(a)(1)(A). ${ }^{102}$ At least one commentator has likewise misunderstood the issue. ${ }^{103}$ The problem identified in Doss creates a significant conundrum.

Fortunately, there is an interpretative solution to the conundrum that carries out Congress' intent to make dischargeable taxes covered by late returns filed more than two years before bankruptcy. The post-petition assessability rule says that taxes which are assessable post-petition because they are "of a kind specified in sections 523(a)(1)(B) and 523(a)(1)(C)" are not to be given priority, even though assessable post-petition under applicable non-bankruptcy law. ${ }^{104}$ The courts (other than Doss) have been interpreting the quoted phrase to mean taxes that are made non-dischargeable by the two referenced subsections of section 523. Instead, they should look to the factual situations addressed in the specified subsections of section 523. Taxes "of a kind specified" in Section 523(a)(1)(B) should be interpreted to mean taxes (1) for which a return was not filed, or (2) for which a return was filed late, regardless of how late. The courts have erred by ignoring the "of a kind" language and excluding from priority only tax claims that are excepted from discharge under section 523(a)(1)(B).

Several appellate courts have considered the interpretation of similar "of a kind" language contained in section 523(a)(1)(A) of the Bankruptcy Code, with mixed results. Section 523(a)(1)(A) provides that taxes "of a kind" specified in section 507(a)(8) are excepted from discharge, whether or not a proof of claim is filed or allowed. The Court

See also In re Treister, 52 B.R. 735, 739 (Bankr. S.D.N.Y 1985) ("The [Doss] court held that simply because a tax was a priority tax under section 507 because still assessable did not mean that the tax was automatically nondischargeable.").

${ }^{100}$ In re Doss, 42 B.R. at 753 ("The court thus concludes that the unassessed taxes for 1976, 1977 and 1978 are not entitled to priority status and shall be considered general unsecured claims.").

${ }^{101}$ See, e.g. In re Crawford, 144 B.R. 346, 347 (Bankr. W.D. Tex. 1992) ("It is difficult to read Doss and understand the interpretation of the relevant Code section"); In re Vitaliano, 178 B.R. at 208 ("[Doss] involves a very dubious reading of the Bankruptcy Code. Although Doss has been widely cited by debtors seeking discharge of tax debts, every court which has considered it has either distinguished it or criticized it.").

10275 B.R. 193, 195 (Bankr. S.D. Fla. 1987).

${ }^{103}$ See Darrell Dunham \& Alex Shimkus, Tax Claims in Bankruptcy, 67 AM. BANKR. L.J. 343, 355 (1993) ("[the Doss court] reasoned that, if the IRS's argument were accepted, then all tax returns filed within three years of the commencement of the case would be within the scope of $\S 507$ (a)(7)(A)(iii). This, of course, would render nugatory $\S 523(\mathrm{a})(1)(\mathrm{B})(\mathrm{ii})$ 's two-year provision.") This is not a correct statement. Section 523(a)(1)(B)(ii) of the Bankruptcy Code would not be rendered nugatory because it applies to make nondischargeable (and 507(a)(7)(A)(iii) makes non-priority) taxes covered by late-filed returns which were filed within two years of bankruptcy. Confusion only exists for taxes filed more than two and fewer than three years before bankruptcy, because section 523(a)(1)(B)(ii) does not make these taxes nondischargeable and they are thus eligible for priority treatment under the post-petition assessability rule in section 507(a)(8)(A)(iii).

${ }^{104} 11$ U.S.C. $\$ 507(\mathrm{a})(8)(\mathrm{A})(\mathrm{iii})$ (emphasis added). 
of Appeals for the Tenth Circuit in In re Victor was first to consider this language ${ }^{105}$. In Victor, two sets of debtors confirmed Chapter 11 reorganization plans in which the government held secured tax liens. ${ }^{106}$ The issue in Victor was whether the government's claim for post-petition pre-confirmation interest, known as "gap" period interest, on its secured tax claims survived the confirmation of the plans, which did not provide for the payment of gap period interest. ${ }^{107}$ The Victor panel first held that the government's claims for gap period interest were not entitled to priority under section 507(a)(8), because only allowed unsecured claims are given priority under that provision, and the government's claim for gap period interest was neither allowed nor unsecured. ${ }^{108}$ The Victor panel relied on an earlier bankruptcy court decision, In re Sproul, ${ }^{109}$ for the proposition that only claims allowable under section 502 would be excepted from discharge under section 523(a)(1). ${ }^{110}$

105121 F.3d 1383 (10th Cir. 1997).

${ }^{106} I d$. at 1384 .

107 Id. at 1383 .

${ }^{108}$ The court stated that the claim for post-petition interest was not allowed because the government had not filed a proof of claim for, and had not objected to confirmation of the plan of reorganization which did not provide for payment of, post-petition interest. See In re Victor, 121 F.3d at 1386. The government argued that it could not have filed a claim for post-petition interest, because section 502(b)(2) disallows claims for un-matured interest. The Victor panel reasoned that this disallowance would not apply to a secured claim for post-petition interest, which is allowed under section 506(b). However, the Court suggested that the government was required to file a claim for, and seek allowance of its claim for, gap period interest, and to object confirmation of any plan that did not provide for payment of gap period interest if it wished to pursue such a claim. Id. at 1387.

10983 B.R. 359 (Bankr. E.D.N.C. 1988). The debtors in Sproul owned farmland subject to a mortgage held by the South Atlantic Production Credit Association ("PCA"). The PCA ultimately got relief from the automatic stay and foreclosed on the property. After foreclosing, the PCA paid the accrued property taxes which had become a priority lien against the property. The PCA then asserted an unsecured claim against the debtors for the unpaid property taxes, arguing that it was a subrogee of the taxing authority. Section 502(b)(3) disallows property tax claims which exceed the value of the estate's interest in the property. Since the value of the debtor's interest in the property was zero, section 502(b)(3) would disallow any claim against the estate on account of the property taxes. Id. at 361. The PCA argued, however, that the claim survived as a non-dischargeable personal liability of the debtor under section 523(a)(1), because the claim was of the kind entitled to priority under section 507(a)(8)(B) (which grants a priority to "allowed unsecured claims of governmental units" for property taxes incurred within one year before bankruptcy). $I d$. The debtor argued that the property tax claims were not "allowed unsecured claims" because of the section 502(b)(3) disallowance. Id. The PCA argued that section 523(a)(1)(A) excepts the claims from discharge "whether or not a claim for such tax was filed or allowed," and therefore its claim should be excepted from discharge. Id. The Sproul court properly held that the language in 523(a)(1)(A) applies only to claims that are allowable, whether or not actually filed or allowed. Id. at 361 ("This legislative history suggests that the language of the final version of $\S 523(\mathrm{a})(1)(\mathrm{A})$ relied on by PCA was intended to prevent the discharge of tax claims which were never filed or filed late but which would otherwise have been allowable, not tax claims which would have been disallowed even if they had been timely filed.").

${ }^{110}$ The Victor panel failed to consider whether the gap period interest was made "allowable" by section 502(i), which provides that tax claims arising after the commencement of the case which are entitled to priority under 507(a)(8), are treated as if they arose before the commencement of the case. If section 502(i) requires the post-petition interest to be treated as if it had arisen prepetition, then it would not constitute unmatured interest as of the petition date and would not be disallowed by section 502(b)(1). The Ninth Circuit Court of Appeals in Miller v. United States, 363 F.3d 999, 1009 (9th Cir. 2004), pointed out that the Victor panel's interpretation would render section 502(i) non-sensical, because section 502(i) references claims entitled to priority under 507(a)(8), and 507(a)(2) references claims allowed under 502(a), creating a chicken and egg cycle that could not be broken. Sproul could have been distinguished from the facts in 
The Victor panel then reasoned that since the interest claim was not entitled to priority, it was also not excepted from discharge under section 523(a)(1)(A). Like the courts considering the relationship between sections 507(a)(8)(A)(iii) and 523(a)(1)(B) and (C), the Victor panel ignored the "of a kind" language in section 523(a)(1)(A), discharging the government's claim because the government failed to file and seek allowance for the claim, notwithstanding the specific language in section 523(a)(1)(A) excepting claims for discharge even if they are not filed or allowed. In its conclusion, the Victor panel suggested that interest on secured tax claims would always be dischargeable, a bizarre result that would treat under-secured tax claimants worse than unsecured tax claimants. $^{111}$

The two circuit courts to consider the issue after Victor have rejected its analysis by focusing on the important "of a kind" language in section 523(a)(1)(A). In In re Gust, the Court of Appeals adopted the opinion of the District Court awarding gap period interest on a secured tax claim. ${ }^{12}$ The government in Gust held prepetition tax liens against the debtor's property to secure trust fund penalties owing for unpaid employment taxes. The debtor filed a "no asset" Chapter 7 case, in which creditors were not required to file proofs of claim, ${ }^{113}$ and the debtor thereafter obtained a general discharge. Two years later, the debtor filed a Chapter 13 case and sought a determination that the government's tax liens did not attach to the debtor's personal property (some of his personal property, apparently, had been exempted in the original Chapter 7 case, and some had been acquired later). ${ }^{114}$ The debtor cited Victor for the proposition that the government's secured tax claims were discharged in his prior Chapter 7 case because only unsecured claims were entitled to priority under section 507(a)(8). ${ }^{115}$ The Gust courts rejected the analysis in Victor, claiming that the Victor panel erred by focusing on the type of "claim" rather than focusing on the type of "tax" at issue. ${ }^{116}$ This was a rather confusing way of saying that when section 523(a)(1) refers to "tax of the kind and for the periods specified in section . . 507(a)(8)," it does not mean a tax claim entitled to priority under section 507(a)(8). Rather, the statute means to refer to taxes of the general

Victor because 502(i) would not have saved the taxes disallowed under section 502(b)(3), because the disallowance was based on value not timing.

${ }^{111}$ Victor, 121 F.3d at 1390 ("We conclude $\S \S 523(a)(1)(A)$ and 507(a)(7) clearly authorize the exception of tax debts and interest from dischargeability under 11 U.S.C. $§ 1141(d)(2)$ only when the governmental entity holds an unsecured claim to that debt.") .

It is important to note that the Victor panel did not discuss whether the government's lien against the property for the gap period interest survived. The government retained its lien under the plan, so the lien would survive the Chapter 11 discharge. See 11 U.S.C. § 1141(c) (property free and clear after confirmation, except as otherwise provided in the plan). The government's tax lien would cover accruing post-petition interest under applicable non-bankruptcy law. Section 506(b) would allow the government's claim for post-petition interest against the property if the value of the property exceeded the claim (which the court said it did). The discharge of the debtor's personal liability under section 1141(d) would not impair the government's claim against the property. See Long v. Bullard, 117 U.S. 617, 620-21 (1886); Dewsnup v. Timm, 502 U.S. 410, 416-17 (1992). One wonders whether the government failed to argue an important theory supporting its right to recovery.

${ }^{112}$ In re Gust, 239 B.R. 630 (S.D. Ga. 1999), aff'd 197 F.3d 1112 (11th Cir. 1999).

${ }^{113}$ See 11 U.S.C. $\S \S 2002(\mathrm{e}), 3002(\mathrm{c})(5)$.

${ }_{114}^{114}$ Gust, 239 B.R. at 631.

${ }^{115} I d$. at $632-33$.

${ }^{116} I d$. at 633 ('Instead of focusing on the type of 'tax', the Victor court focused on the type of 'claim.' This focus was in error."). 
type discussed in section 507(a)(8). By so interpreting the inartful statutory language, the Gust courts sought to avoid the absurd result of causing otherwise nondischargeable taxes to be discharged simply because the government held security for its claim. ${ }^{117}$ Like the panel in Victor, the courts in Gust did not discuss the effect of the personal discharge on an existing secured claim. ${ }^{118}$

In Miller v. United States, ${ }^{119}$ the Court of Appeals for the Ninth Circuit, in an opinion written by a former Tax Court Judge Cynthia Holcomb Hall, ${ }^{120}$ followed the Gust court's logic in holding that gap period interest on a secured tax claim is excepted from discharge under section 523(a)(1)(A), even though the tax claim would not be entitled to priority under section 507(a)(8). The panel in Miller rejected the Victor court's analysis because it "would render superfluous the plain language of $\S 523(\mathrm{a})(1)$, which preserves debts for particular types of taxes "whether or not a claim was filed or allowed.","121 The panel in Miller also pointed out that the "unsecured" language in section 507(a)(8) is not rendered superfluous, because only unsecured claims would receive priority in distribution from the estate. ${ }^{122}$ Secured claims would not be entitled to priority, ${ }^{123}$ but

${ }^{117}$ See id. at 634 ("Gust's position contravenes this policy [of preventing the discharge of tax claims] and would result in illogical outcomes. Under the Gust court's reasoning, the tax debt would be nondischargeable only if the IRS had done nothing to secure the tax debt because it would be 'unsecured' under $\S 507(\mathrm{a})(8)$. Here, the Bankruptcy Court was correct in concluding that 'Section 523(a)(1)(A) addresses 'debt' arising from 'a tax', 'of the kind' specified in $\S 507(\mathrm{a})(8)$, not debt evidenced by a claim described in $\S 507(\mathrm{a})(8)$.'").

${ }^{118}$ The District Court in Gust cited In re Frengel, 115 B.R. 569, 571 (N.D. Ohio 1989), for the proposition that tax claims are not rendered dischargeable by being secured. Gust, 239 B.R. at 633. Frengel, however, dealt with whether a tax lien was discharged where the tax liability was clearly dischargeable (presumably, outside of the priority period in section 507(a)(8)). The Bankruptcy Court in Frengel, citing to Long $v$. Bullard and its progeny, discussed supra at note 111, held that tax liens are not discharged by a general bankruptcy discharge - even where the debtor's personal liability for the underlying claim is discharged. Frengel, 115 B.R. at 570-71. Frengel did not involve a tax "of a kind" excepted from discharge under section 507(a)(8). While Frengel would support the non-dischargeability of the government's tax lien on the property held by the debtor in Gust on the date of discharge, it does not support the holding in Gust that taxes not given priority under section 507(a)(8) may nevertheless be taxes "of a type" covered by section 507(a)(8). The Gust courts failed to address the separate issue concerning the validity of the government's lien on the debtor's property at the time the discharge was granted. This omission is curious in light of the Court citation to Frengel.

The district court in Gust also cited In re Latulippe, 13 B.R. 526 (Bankr. D.V. 1981), which considered whether a secured tax claim could be enforced against property exempted by the debtor in bankruptcy. The Latulippe court rejected out of hand as illogical (and contrary to the legislative history of the statute) the debtor's suggestion that the tax claim was not excepted from discharge under 523(a)(1) because it was secured. See Latulippe, 13 B.R. at 527 ("[I]t seems illogical that it was the intent of Congress to make unsecured claims for taxes non-dischargeable while at the same time rendering a claim for taxes dischargeable if the governmental unit has taken steps to enforce payment of an un-dischargeable tax claim by imposing a lien on the taxpayer's property."). After holding that the tax claim was excepted from discharge, the Latulippe court held that the property remained subject to the government's tax lien. 119363 F.3d 999 (9th Cir. 2004).

${ }^{120}$ According to her biography, Judge Hall served on the Tax Court from 1972-1981. See http://www.appellate-counsellor.com/profiles/hall.htm.

${ }^{121}$ Miller, 363 F.3d at 1007.

${ }^{122} I d$. at $1008-09$.

${ }^{123}$ Although not discussed in the opinion, secured claims would, of course, be entitled to priority in distribution from the collateral. According to the theory advanced by the Miller panel, under-secured claims would not be entitled to priority in distribution from the estate under section 507(a)(8). 
would nevertheless be excepted from discharge because they are claims "of the kind" covered by the priority statute.

One problem with the opinions in Victor, Gust and Miller is that they all ignore the Bankruptcy Code's distinctive treatment of secured and unsecured claims. There is no such thing as an under-secured claim under the Bankruptcy Code. Section 506(a) bifurcates a single under-secured claim into two separate claims: a secured claim to the extent of the value of the collateral, and an unsecured claim for the deficiency. ${ }^{124}$ In most cases, a secured claimant will not need priority in distribution vis à vis unsecured creditors because the secured claim is fully covered by, and will be paid in full either from the sale of collateral or, with interest, under the plan of reorganization. ${ }^{125}$ Indeed, a secured creditor is entitled to a special super-priority if the court erroneously over-values the collateral in finding the secured creditor to be adequately protected. ${ }^{126}$ It is only with respect to gap period interest - the interest which would accrue between the time of the filing of the petition and the date of confirmation - that the under-secured creditor bears a potential risk loss on its secured claim. ${ }^{127}$ There should have been no issue if the taxing authority in Victor, Gust, and Miller had been over-secured - section 506(b) would have allowed gap period interest, and the estate would have had to pay the entire claim either from the sale of the collateral, or pursuant to the terms of a plan of reorganization. ${ }^{128}$ On the other hand, if the taxing authority had been under-secured, the unsecured portion of the claim should have been entitled to priority under section 507(a)(8), and would have been non-dischargeable under section 523(a)(1). The three courts erred by failing to address the fact that an under-secured creditor has a plain vanilla unsecured claim in bankruptcy for the portion of the claim that is not covered by the value of the collateral. They also erred by failing to address that the secured portion of the claim would have to be paid either from the sale of the collateral or under a plan. The issue in Victor, Gust, and Miller should have concerned only the narrow question of the taxing authority's entitlement to gap period interest on the secured portion of the claim. In any case, the Gust and Miller courts correctly focused on the "of the kind" language in section 523(a)(1) to hold that gap period interest on a secured claim would be excepted from discharge under the "of a kind" language, even though the claim would not itself be entitled to priority under section $507(\mathrm{a})(8){ }^{129}$

\footnotetext{
${ }^{124} 11$ U.S.C. $\$ 506$ (a) (“An allowed claim of a creditor secured by a lien on property ... is a secured claim to the extent of the value of such creditor's interest in the estate's interest in such property . . . and is an unsecured claim to the extent that the value of such creditor's interest . . . is less than the amount of such allowed claim.").

${ }^{125}$ Under the reorganization chapters, the secured claim must be paid in full with interest from the effective date of the plan. See $\S \S 1129(\mathrm{~b})(2)(\mathrm{A})(\mathrm{i})(\mathrm{II})$ (payments must total, and where the claim is fully secured must have a "value as of the effective date of the plan" equal to, the allowed amount of secured claim); 1225(a)(5)(B)(ii) (same); 1325(a)(5)(B)(ii) (same). The Supreme Court in Till v. SCS Credit Corp., 541 U.S. 465,467 (2004), interpreted "value as of the effective date of the plan" to require the payment of interest at the prime rate plus a premium for the additional risk that a loan to the debtor carries over the risk of a loan to a prime-rate-qualified borrower.

12611 U.S.C. $\$ 507(\mathrm{~b})$.

${ }^{127}$ If the creditor is over-secured, the creditor is entitled to recover post-petition gap period interest. 11 U.S.C. $\S 506(b)$.

${ }^{128}$ See note 125 .

${ }^{129}$ As a general matter, it would appear that both an under-secured creditor and an unsecured creditor would be treated the same - both would not be denied the right to recover gap period interest as a claim
} 
The same theory that allowed the Gust and Miller panels to find that gap period interest, which was not entitled to priority under section 507(a), could still be "of the kind" entitled to priority under 507(a)(8), should be used in interpreting the "of a kind" language in section 507(a)(8)(A)(iii). That is, even though a claim for taxes covered by a late return filed more than two but fewer than three years before bankruptcy would not be excepted from discharge under section 523(a)(1)(B), the taxes could still be "of a kind" specified in section 523(a)(1)(B). Using a proper interpretation of the statutory language, taxes covered by a late return filed more than two years but fewer than three years before bankruptcy would be dischargeable. The taxes would not be excepted from discharge by section 523(a)(1)(B), because the late return was filed more than two years before bankruptcy. The taxes would also not be entitled to priority under section 507(a)(8)(A)(iii), because the only reason the taxes are assessable post-petition is because a return was filed late - hence the kind of taxes addressed in section 523(a)(1)(B). Had the return been filed timely, assessment would have been barred under applicable nonbankruptcy law by the three year limitations period. Since the sole reason the taxes are assessable post-petition is because the return was filed late, the taxes would not be entitled to priority under the post-petition assessability rule of section $507(\mathrm{a})(8)(\mathrm{A})(\mathrm{iii}){ }^{130}$ In turn, if the taxes are not entitled to priority, they would not be excepted from discharge

against the estate. This is because section 502(b)(2) generally disallows claims for un-matured interest, and the section 506(b) exception applies only to over-secured creditors.

However, it could be argued that section 502(i) allows an unsecured tax claimant holding a priority claim under section 507(a)(8) to recover gap period interest. Section 502(i) says that a claim that does not arise until after the case (here, the claim for post-petition interest) will be treated under section 502 as if it had arisen before the commencement of the case. 11 U.S.C. § 502(i). Does this mean that gap period interest will be treated as having arising prepetition, in which case it would not constitute "unmatured" interest? If so, then unsecured tax creditors holding priority claims would be entitled to gap period interest, while under-secured tax creditors would only be entitled to gap period interest on the unsecured portion of their claims (the secured portion of their claims would not be entitled to priority under 507, and therefore would not qualify for prepetition treatment under section 502(i). I could find no cases directly addressing this issue. The bankruptcy court in In re Patch Press, Inc., 71 B.R. 345 (Bankr. W.D. Wis. 1987), suggested in dicta (it was considering whether interest was recoverable on a post-petition tax claim) that "[s]ince tax claims can accrue post-petition, see 11 U.S.C. $\S 502(i)$, it is not unreasonable that interest should also accrue post-petition as part of the claim." Id. at 350. If this is a correct interpretation of section 502(i), then an unsecured claim that is entitled to priority under section 507(a)(8) would also be entitled to accrue gap period interest, while the secured portion of an under-secured creditor's claim would not.

However, several courts have held that section 502(i) was intended to cover only taxes relating to prepetition activities for which the liability is deemed under applicable non-bankruptcy law to arise postpetition. These courts rejected the argument that section 502(i) applies to treat post-petition taxes as if they arose prepetition (even though post-petition taxes fit within the literal language of section 502(i)). See, e.g. In re St. Louis Freight Lines, Inc., 45 B.R. 546, 549 (Bankr. E.D. Mi. 1984) (following Collier on Bankruptcy's suggestion that section 502(i) was intended to cover only prepetition taxes that are assessed post-petition); In re Razorback Ready-Mix Concrete Co., 45 B.R. 917, 925 (Bankr. E.D. Ark. 1984). Similarly, if section 502(i) was not intended to cover gap period interest (the liability for which, like postpetition taxes, does not come into existence until post-petition), then the treatment of the secured portion of an under-secured tax lien would be treated the same as any unsecured tax claim - gap period interest would not be recoverable. This is the preferable result to accord similarly situated creditors with equal treatment in distribution.

${ }^{130}$ See I.R.C. § 6501(a) (three year rule). If a longer period of limitations applies for a reason other than the late-filing of the return, then there is an independent basis for priority and non-dischargeability. See discussion, supra, at note 90 . 
under section 523(a)(1)(A). The result intended by Congress - that taxes covered by late returns filed more than two years before bankruptcy would be dischargeable - is achieved. The court in Doss thus got the rule right - the taxes should be dischargeable and not subject to priority. Unfortunately, the Doss court did a poor job of developing a proper rationale for its holding.

Congress' use of vague cross-references in section 507(a)(8)(A)(iii) (and in section 523(a)(1)(A)) has created unnecessary confusion about whether claims arising from late-filed returns are entitled to priority. Under a correct interpretation of the "of a kind" language, a claim for taxes which is assessable post-petition solely because the debtor failed to file a return, or filed a late return, should not be entitled to priority under section 507(a)(8)(A)(iii), regardless of when the late return was filed. In order to make sense of the statute, the "of a kind" language should be interpreted as a reference to the general category of taxes discussed in the referenced statute, rather than to whether the taxes in fact meet the specific test in the referenced statute. ${ }^{131}$

\section{B. Pre-petition Taxes in the Year of Bankruptcy.}

On its face, all taxes incurred in the year of bankruptcy - both prepetition and post-petition - appear to be covered by the post-petition assessability rule of section

\footnotetext{
${ }^{131}$ A second oddity caused by the vague reference in section 507(a)(8)(A)(ii) to taxes "of a kind specified" in section 523(a)(1)(C) concerns taxes for which the debtor substantially understated income. If the debtor intentionally understated income, the government's claim would likely be excepted from discharge under section 523(a)(1)(C), which excepts from discharge tax claims with respect to which the debtor filed a fraudulent return or willfully attempted to evade or defeat the taxes. Since the claim is excepted from discharge under section 523(a)(1)(C), it would likewise not be entitled to priority under the post-petition assessability rule. But if the debtor unintentionally understated its income - no "fraud" or a "willful attempt to evade or defeat" the taxes - then the taxes would not be excepted from discharge under section 523(a)(1)(C). Since not excepted from discharge, the taxes would be entitled to priority under the postpetition assessabilty rule of section 507(a)(8)(A)(iii) if assessable post-petition. The Tax Code provides for a longer six year period of limitations on assessments when the debtor makes a "substantial understatement" of income, even though the debtor lacked any wrongful intent in making the understatement. See I.R.C. § 6501(e)(1)(A). A "substantial understatement" occurs if the understatement exceeds 25 percent of the income reported. I.R.C. $\S 6662(\mathrm{e})(1)(\mathrm{A})$. Thus, the statute would treat tax claims arising from the debtor's innocent error better vis à vis other creditors than tax claims arising from the debtor's intentional fraud. Worse, even though the unintentional understatement is not excepted from discharge under 523(a)(1)(C), the claim would still be excepted from discharge through the back door of section 523(a)(1)(A) (which excepts from discharge all claims entitled to priority). The Court in In re Zeig, 206 B.R. 974, 977 (Neb. 1997), allowed a debtor who had embezzled money to discharge the tax claim under a Chapter 13 plan without providing for any payments on the claim. The government argued that the result was perverse because the debtor would have had to pay the claim in full if the debtor's "substantial understatement" had been unintentional - the debtor would have been required to provide for full payment of a priority claim in a Chapter 13 plan. 11 U.S.C. § 1322(a)(2). The Court nevertheless held for the debtor. Zeig, 206 B.R. at 977 ("[T] perverse result in that debtors can benefit from their fraud and avoid paying their income tax debt. While this may be the effect of the bankruptcy court's ruling ... the bankruptcy code has produced similar seemingly inequitable results. ... [I]n those instances, Congress corrected the inequity. . . . [I]f the law needs to be changed, Congress must change the law. That is not the job of the courts."). There is, of course, no good reason for giving the government a priority claim over other creditors if the debtor commits an unintentional understatement within seven years of bankruptcy, but not to give priority if the understatement was intentional. This is yet another example of the problems caused when Congress references another body of law without understanding the implications of its reference.
} 
507(a)(8)(A)(iii). Taxes incurred in the year of bankruptcy could not have been assessed $^{132}$ before the bankruptcy petition was filed, since the amount is only determinable at the end of the tax year, and the taxes would be assessable under applicable nonbankruptcy law after bankruptcy, since the three-year statute of limitations on assessment does not even begin to run until, at the earliest, the due date of the return for the taxes. ${ }^{133}$ Under this literal reading of the statute, post-petition taxes would never be entitled to first priority as administrative expenses, because such taxes would always

\footnotetext{
${ }^{132}$ A different issue was presented by the use of the term "assessed" with respect to property taxes. Under some state laws, a property tax assessment is made before the taxes become a lien against the property and the owner becomes liable for payment. Prior to the 2005 Act, property taxes "assessed" prepetition (and not more than one year before bankruptcy) were entitled to eighth priority (11 U.S.C. § 507(a)(8)(B), and were thus not entitled to priority as administrative expenses. 11 U.S.C. $\S 503$ (b)(1)(B)(i). The debtor argued in In re Federated Department Stores, Inc., 270 F.3d 994 (6th Cir. 2001), that property taxes incurred by the estate for a post-petition were not entitled to be treated as administrative expenses because the taxes had been assessed under New York law prepetition. The panel struggled with the statutory language and the obvious intent that the post-petition taxes be administrative expenses, ultimately adopting a federal definition of "assessed" that focuses on the debtor's liability for the taxes. Most other courts considering the property tax issue adopted similar reasoning. See In re King, 961 F.2d 1423, 1427 (9th Cir 1992) (tax is not "assessed" until fixed and final); In re Fairchild Aircraft Corp., 124 B.R. 488, 494 (Bankr. W.D. Tex. 1991) ("assessed" refers to the date taxpayer's liability is determined, not prior date fixing value of property); In re Kamstra, 51 B.R. 826, 833 (Bankr. W.D. Mich. 1985) (same); In re Stroud, 37 B.R. 735, 741-42 (Bankr. E.D.N.C. 1984) (assessed when taxed due, not when lien arises); In re Scrap Disposal, Inc., 24 B.R. 178, 180 (Bankr. S.D. Cal. 1982) aff'd, 38 B.R. 765 (B.A.P. 9th Cir. 1984) ("assessment" occurs when liability arises); In re Davis, 11 B.R. 621, 622-23 (Bankr. N.D. Tex. 1981) ("assessment" requires the fixing of a tax liability, not merely valuing property). Earlier, several courts had focused on the date the lien attaches. See In re Prairie Mining, Inc., 194 B.R. 248, 257 (Bankr. D. Kan. 1995); In re Grivas, 123 B.R. 876, 881 (Bankr. S.D. Cal. 1991); In re Point Rest. \& Oyster Bar, 86 B.R. 252, 254 (Bankr. N.D. Fla. 1988). See also In re Members Warehouse, Inc., 991 F.2d 116, 118-19 (4th Cir. 1993) (adopting state law definition of "incurred."). While the courts differed on when precisely property taxes are "assessed" for purposes of section 507(a)(8)(B), the court in In re Solomon Financial. Services., No. 91-4-3084, 1996 Bankr. LEXIS 1915 *9 (Bankr. Md. 1996), who of course followed the majority view, could find only one published decision in which a court had found taxes to have been "assessed" on the date that the value of the property was fixed - In re T \& T Roofing and Sheet Metal, Inc., 156 B.R. 780 (Bankr. N.D. Tex. 1993).

In the 2005 Act, Congress ended the debate by amending section 507(a)(8)(B). Instead of using the word "assessed," Congress substituted the word "incurred," thus properly focusing on the period to which the taxes related. The property tax imbroglio may have been foremost on Congress's mind when moved up from section 507(a)(8)(A)(i) language granting priority only to taxes for years ending prepetition. See discussion infra after note 265.

The proper definition of the word "assessed" is when the tax liability is reflected in the taxpayer's records as owing and becomes due and payable. I.R.C. $\S \S 6201,6203$ (recording in records). See Bullv. United States, 295 U.S. 247 (1935); see also I.R.C. § 6331(a).

The problem of interpreting a poorly written statute to carry out the logical intent of Congress was recently discussed by Judge Posner in In re Handy Andy Home Improvement Centers., Inc., 144 F.3d 1125, 1127 (7th Cir. 1998). The issue in Handy Andy was whether a landlord would be entitled to an administrative claim for prepetition property taxes reimbursable under the lease by the tenant. Posner held that the statutes must be viewed in context rather than in a hyper-technical way. See also Heathcon Holdings, LLC v. Dunn Indus., LLC, 320 B.R. 86, 93 (Bankr. D. Md. 2005) (following Handy Andy in requiring allocation of amounts accruing both prepetition and post-petition); but see In re Montgomery Ward Holding Corp., 268 F.3d 205, 211 (3rd Cir. 2001) (applying what the court called a "bright line test").

${ }^{133}$ See I.R.C. $\$ 6501$ (a) (general rule that government has three years from the time a return is filed to assess a deficiency). But returns filed before the due date for the return do not start the limitations period running. See I.R.C. $\S 6501(\mathrm{~b})(1)$ (return filed before due date is treated as filed on due date).
} 
be entitled to priority under section 507(a)(8), and would thus be specifically excepted from the definition of an administrative expense. ${ }^{134}$

This literal interpretation of the statute is inconsistent with the legislative history, ${ }^{135}$ and has been repeatedly rejected by the courts. ${ }^{136}$ Those courts who offered any reasoning at all to support their holding that Congress intended only prepetition taxes to be covered by the post-petition assessability rule simply found that any other result would be "absurd." 137

There is a way to reach the conclusion that taxes on post-petition income are not entitled to priority under the post-petition assessability rule, without resorting to namecalling. Eighth priority is given only to "allowed unsecured clams." 138 This is a reference to the claim allowance provision in section 502 of the Bankruptcy Code which provides for the allowance of claims that are in existence as of the petition date. ${ }^{139}$ As a general matter, claims that first arise for bankruptcy purposes after the petition date are not "allowed claims" under section $502,{ }^{140}$ and are thus not entitled to priority under section 507(a)(8). Unlike section 502, which provides for "allowed claims," post-petition claims under section 503(a) and (b) are referred to as "administrative expenses." The

\footnotetext{
${ }^{134} 11$ U.S.C. $\S 503(\mathrm{~b})(1)(B)$ (taxes incurred by the estate are administrative expenses "except a tax of a kind specified in section 507(a)(8) of this title.").

${ }^{135}$ United States v. Redmond, 36 B.R. 932, 934 (D. Kan. 1984) (“'The actual, necessary costs and expenses of preserving the estate, including wages ... rendered after the commencement of the case, and any taxes on, measured by or withheld from such wages . . . are allowable as administrative expenses.' S.Rep. No. 95-989, 95th Cong., 2d Sess. 66, reprinted in 1978 U.S.Code Cong. \& Ad.News 5787, 5852; H.R.Rep. No. 95-595, 95th Cong., 1st Sess. 355, reprinted in 1978 U.S.Code Cong. \& Ad.News 5963, 6311. The Senate Report, supra, further states that '[i]n general, administrative expenses include taxes which the trustee incurs in administering the debtor's estate."').

${ }^{136}$ See, e.g. In re Westholt Mfg., Inc., 20 B.R. 368, 371 (Bankr. D. Kan. 1982) (“a tax given priority status under section 507(a)(6) and predicated on pre-petition liability incurred by the debtor before the filing of the petition should not be promoted to a first priority administrative expense merely because it is assessed after the petition is filed. On the other hand, actual, necessary costs and expenses of preserving the estate ... should not be denied administrative status merely because in character the claims resemble claims for taxes described in section 507(a)(6)"), aff'd United States v. Redmond, 36 B.R. 932, 934 (Bankr. D. Kan. 1984) (stating that taxes are "incurred" when they accrue); In re L.J. O'Neill Shoe Co., 64 F.3d 1146,1151 (8th Cir. 1995) ("We believe that subsection (iii) can be read, like the other subsections of 507(a)(7)(A), to address only prepetition taxable activity or events"); In re Pacific-Atlantic Trading Co., 64 F.3d 1292, 1303 (9th Cir. 1995) (rejecting government's argument that the panel's interpretation of 507(a)(8)(A)(iii) would apply to all post-petition taxes: "[W]e will not presume Congress intended an absurd result.... Taxes for periods which occur entirely post-petition are afforded an administrative expense priority under $\S 503(\mathrm{~b})(1)(\mathrm{B})$. Congress certainly did not intend for taxes earned entirely postpetition to be 'relegated' to seventh level priority") (citations omitted); In re EMC Indus., Inc., 27 B.R. 696 (Bankr. D. S.C. 1983).

${ }^{137}$ See, e.g. Pacific-Atlantic Trading Co., 64 F.3d at 1303, quoted supra at note 136; see also In re O.P.M. Leasing Servs., Inc., 68 B.R. 979, 983-84 (Bankr. S.D.N.Y. 1987).

${ }^{138}$ See 11 U.S.C. $\S 507(\mathrm{a})(8)$.

${ }^{139}$ Section 502(b) provides that, after the filing of an objection, the court will allow claims after determining "the amount of such claim in lawful currency of the United States as of the date of the filing of the petition." 11 U.S.C. $\S 502$ (b). Claims that did not exist as of the date of the filing of the petition would not be allowed in any amount, because nothing was owing as of the petition date. This is to be distinguished, of course, from claims which exist prepetition, but are not ripe for payment or enforcement (such as contingent claims, unliquidated claims and unmatured claims). See 11 U.S.C. § 101(5) (definition of claim).

${ }^{140} \mathrm{Id}$.
} 
priority granted by the post-petition assessability rule in section 507(a)(8)(A)(iii) only applies to "allowed claims" not to "allowed administrative expenses."

This analysis begs the question about whether the taxes incurred in the year of bankruptcy constitute prepetition tax claims or post-petition tax claims. The division is easy if an individual debtor in a Chapter 7 or 11 case elects to make the split-year election. When the election is made, the debtor's tax year for the year of bankruptcy is split into two tax years, consisting respectively of a prepetition "year" and a post petition "year." 141 If the election is made, the taxes owed for the pre-petition partial "year" are treated as Section 507(a)(8) pre-petition priority taxes, ${ }^{142}$ and taxes owed for the postpetition partial "year" are treated as 507(a)(1) administrative expenses if the benefit of the income redounded to the estate, or as personal obligations of the debtor if the benefit redounded to the debtor as part of the debtor's "fresh start.",143

The complexity arises if the split year election is not (or, in the case of corporate entities $^{144}$ or individual debtors in Chapter 12 or 13 cases, ${ }^{145}$ cannot be) made. In cases where the election is not or cannot be made, it is necessary to determine whether the taxes for the year of bankruptcy are first priority administrative expenses, eighth priority unsecured claims, somehow divisible between the two, or non-priority general unsecured claims.

Income taxes that are entitled to eighth priority are automatically excluded from being treated as first priority administrative expenses. ${ }^{146}$ Income taxes incurred in the year of bankruptcy can only be entitled to eighth priority if the post-petition assessability rule applies, because the other two priority-granting rules cannot apply to year-ofbankruptcy taxes when the split year election is not made. The lookback rule ${ }^{147}$ could never apply to income taxes incurred in the year of bankruptcy, absent a split year election or a petition filed on the last day of the tax year, because, by its terms, the rule only applies to taxes "for a taxable year ending on or before the filing of the petition."148 Unless the debtor files on the last day of the tax year, the year in which the petition is filed will not have ended on or before the petition date. Similarly, income taxes incurred in the year of bankruptcy could not have been assessed before bankruptcy under the 240-

\footnotetext{
${ }^{141}$ I.R.C. § 1398(d)(2).

${ }^{142}$ The taxes for the prepetition "year" of filing would be entitled to priority under both the lookback rule (11 U.S.C. $\S 507(a)(8)(A)(i)$ ) and the post-petition assessability rule (11 U.S.C. § 507(a)(8)(A)(iii)). The lookback rule would apply because the prepetition year terminated "on" the petition date, and the return for the year would be due after the 3 year lookback period (indeed, the return would be due after the petition was filed). The post-petition assessability rule would apply because the period of assessment would not even begin to run until the return for the tax year is due. See supra note 133.

${ }^{143}$ By definition, the taxes owing for the post-petition tax year were not incurred prepetition. To be administrative expenses, the taxes must have been "incurred by the estate." If the estate is "entitled to the income" then the estate is taxed on the income (I.R.C. § 1398(e)(1)) and the debtor is not taxed on the income (I.R.C. $\S 1398(\mathrm{e})(2))$. If the estate did not get the income, then nothing in the Bankruptcy Code would allow the government to have a claim against the estate for repayment.

${ }^{144}$ Only individuals are eligible to make a split-year election. I.R.C. § 1398(a).

${ }^{145}$ The election can only be made by debtors in Chapter 7 or 11 cases. Id.

14611 U.S.C. $\$ 503(\mathrm{~b})(1)(\mathrm{B})(\mathrm{i})$.

147 11 U.S.C. $\$ 507(\mathrm{a})(8)(\mathrm{A})(\mathrm{i})$.

${ }^{148}$ Prior to the 2005 Act, this language was in the lookback rule itself. 11 U.S.C. $\S 502(a)(8)(A)(i)$ (repealed 2005). After the 2005 Act, this language was moved to 11 U.S.C. § 502(a)(8)(A), and applies to the lookback rule, the 240 day rule, and the post-petition assessability rule. As is discussed below, the change only has an impact on the post-petition assessability rule.
} 
day rule of section $507(\mathrm{a})(8)(\mathrm{A})(\mathrm{ii}) .{ }^{149}$ Therefore, the post-petition assessability rule of section 507(a)(8)(A)(iii) is the only provision in section 507(a)(8) that could apply to income taxes incurred in the year of bankruptcy (unless the debtor makes a split-year election or files bankruptcy on the last day of the tax year).

Does the post-petition assessability rule of section 507(a)(8)(A)(iii) apply to make priority all or part of the taxes owing for the year of bankruptcy? First, as discussed above, taxes on post-petition income should not be covered by the post-petition assessability rule, because the taxes do not constitute "allowed unsecured claims."150 So the real question is whether taxes on income earned prepetition in the year of bankruptcy will be covered by the post-petition assessability rule of section 507(a)(8)(A)(iii).

Prior to the 2005 Act, courts applied different rules for corporations and for individuals who did not make the split year election in deciding whether taxes on income earned prepetition in the year of bankruptcy were covered by section 507(a)(8)(A)(iii).

\section{i. Corporate Taxpayers.}

The courts have consistently held that the obligation of corporate taxpayers ${ }^{151}$ to pay taxes on income earned prepetition is covered by the post-petition assessability rule, ${ }^{152}$ and is therefore not entitled to priority as an administrative expense. ${ }^{153}$ The issue was considered at length by the Court of Appeals for the Ninth Circuit in In re PacificAtlantic Trading Co. ("PATCO”). ${ }^{154}$ The PATCO panel considered whether corporate income taxes incurred in the year of bankruptcy would be treated as first priority expenses of administration or as eighth priority claims under the post-petition assessability rule. The debtor in PATCO did not operate post-petition, and therefore it appeared that all income taxes owing for the year of bankruptcy were attributable to prepetition earnings. After carefully reviewing the legislative history, the PATCO panel first determined that Congress intended all taxes for the year of bankruptcy be treated as "incurred" on the last day of the taxable year. ${ }^{155}$ The Ninth Circuit panel's focus on the

\footnotetext{
${ }^{149}$ An assessment cannot be made until after the tax return for the year is due. See I.R.C. $\S \S 6201(a)$, 6213(a).

${ }^{150}$ See supra beginning at note 132 .

${ }^{151}$ Note that, unlike an individual taxpayer, a corporate taxpayer does not receive a discharge under Chapter 7. 11 U.S.C. $\S 727(a)(1)$. This is because corporate taxpayers, unlike individual taxpayers, cease to exist following liquidation in Chapter 7. The corporate taxpayer's assets are sold, creditors are paid from the proceeds, and only an inactive corporate shell remains. Individual debtors, on the other hand, continue to live their lives and need the fresh start provided by the discharge.

In a Chapter 11 case, a corporate debtor may continue to operate after confirmation of a plan of reorganization, and therefore needs the fresh start that a discharge provides. The Chapter 11 discharge for corporations is broader than the Chapter 11 discharge for individuals. Corporations are able to discharge obligations that would not be dischargeable to an individual. See 11 U.S.C. $\S \S 1141(d)(1), 1141(d)(2)$ (excepting from an individual debtor's Chapter 11 discharge debts not dischargeable under section 523). However, under the 2005 Act, the Chapter 11 discharge will not discharge corporate debtors from tax debts arising out of fraudulent returns or willful attempts to evade or defeat taxes. See 11 U.S.C. § 1141(d)(6)(B) (2005).

${ }^{152} 11$ U.S.C. $\S 507(\mathrm{a})(8)(\mathrm{A})(\mathrm{iii})$.

15311 U.S.C. $\S 503(\mathrm{~b})(1)(\mathrm{B})(\mathrm{i})$.

15464 F.3d 1292 (9th Cir. 1995).

${ }^{155} \mathrm{Id}$. at 1301 ("The pertinent legislative history clearly demonstrates that the drafters of $\S 503(\mathrm{~b})(1)(\mathrm{B})(\mathrm{i})$ intended that a tax on income should be treated as "incurred" on the last day of the taxable period."). The
} 
legislative history is curious, ${ }^{156}$ as nothing in the statute suggests that taxes accruing prepetition in the year of bankruptcy should be treated as "incurred" at the end of the tax year. ${ }^{157}$ The panel then held that although the taxes were deemed to have been "incurred" by the estate post-petition, the taxes also fell within the literal wording of the postpetition assessability rule, ${ }^{158}$ and would therefore be an eighth priority claim and not entitled to first priority as an administrative expense.

The government objected that the panel's reading of the post-petition assessability rule would treat all taxes incurred by the estate post-petition as eighth rather than first priority - including taxes for years beginning after the petition date. Although the government's argument was logical, the PATCO panel called the argument "absurd.",159 The panel stated that it was following two other bankruptcy court opinions ${ }^{160}$ in holding

panel recognized that a New York bankruptcy court in In re O.P.M. Leasing Services., Inc., 68 B.R. 979, 983-84 (Bankr. S.D.N.Y. 1987), had previously concluded that taxes in the year of bankruptcy are incurred as they accrue. The Panel rejected the O.P.M. Court's interpretation because it had not considered legislative history which, the panel believed, indicated an intent to adopt a definition of "incurred" contained in the version of the Bankruptcy Code adopted by the Senate Finance Committee. The definition proposed by the Senate Finance Committee was not included in the final version of bill which became law. Nevertheless, the House and Senate managers discussing the final bill stated an intent to adopt the deleted portion of the Senate Finance Committee's version. As stated by the PATCO court: "final statements of both House and Senate sponsors, Representative Edwards and Senator DeConcini, reflect that Congress intended that the compromise bill adopt the substance of the Senate Finance Committee's definition of 'incurred." PATCO, 64 F.3d at 1300. Of course, it would be just as easy to conclude (regardless of what the House and Senate managers intended), that by omitting the language from the bill, Congress intended the accrual result determined by the bankruptcy court in O.P.M.. After all, if they intended to follow the Senate Finance Committee's definition, why was the language omitted? Both sides are attempting to determine the meaning of Congress' omission, which is a fruitless task. The legislative history is ambiguous.

${ }^{156}$ See discussion infra beginning at note 237 regarding the propriety of using legislative history to create an ambiguity in the statute.

${ }^{157}$ See In re Garfinckels, Inc., 203 B.R. 814, 820 (Bankr. D.D.C. 1996) ("Setting aside this court's concerns about the dubious nature of [the PATCO panel] relying on unenacted proposed legislation."); $\mathrm{c} f$. United States v. Ron Pair Enter., Inc., 489 U.S. 235, 242 (1989) (courts should look beyond the text of a statute only in "rare cases [in which] the literal application of a statute will produce a result demonstrably at odds with the intentions of its drafters") (citations omitted).

${ }^{158}$ PATCO, 64 F.3d at 1302 ("The tax at issue, however, fits on its face within the narrow parameters set by $\S 507(\mathrm{a})(7)(\mathrm{A})($ iii). Since $\S 507(\mathrm{a})(7)(\mathrm{A})(\mathrm{iii})$ is satisfied, $P A T C O$ 's liability for the 1988 taxes is excepted from $\S 503$ and given seventh priority.")

${ }^{159}$ Like the taxes in the year of bankruptcy, taxes for an entirely post-petition year were not assessed before and are assessable after the petition date. The PATCO panel rejected the government's argument that, under the panel's theory, taxes for an entirely post-petition year would also fit within the post-petition assessability rule: "We will not presume Congress intended an absurd result. ... Taxes for periods which occur entirely post-petition are afforded an administrative expense priority under $\S 503(b)(1)(B)$. Congress certainly did not intend for taxes earned entirely post-petition to be "relegated" to seventh level priority status. PATCO, 64 F.3d at 1303.

${ }^{160} I d$. at 1303-04 citing In re Interco, Inc., 143 B.R. 707 (Bankr. E.D. Mo. 1992), aff'd sub nom. In re L.J. O'Neill Shoe Co., 64 F.3d 1146 (8th Cir. 1995), discussed supra note 159, and In re O.P.M. Leasing Services., Inc., 68 B.R. 979 (Bankr. S.D.N.Y. 1987). In Interco, the court issued two orders regarding priority claims. One order set a bar date for creditors holding priority claims other than administrative claims to file proofs of claim with the court. The other order stated that administrative claimants were not required to file claims by the priority claim bar date. The Missouri Department of Revenue did not file a proof of claim for the year of bankruptcy, claiming that all of the taxes for the year of bankruptcy were entitled to administrative priority. The Interco court ultimately split the baby, holding "that the taxes 
that income taxes incurred in the year of bankruptcy would be treated as eighth priority under the post-petition assessability rule. ${ }^{161}$ After determining that the post-petition assessability rule applied to taxes for a prepetition period that are deemed to have been incurred post-petition, it was a straightforward matter of statutory interpretation to hold that the taxes were not entitled to administrative priority. ${ }^{162}$ The PATCO panel did not adequately reconcile its ruling that the tax claim accrued post-petition (at the end of the year) with its ruling that the taxes would be treated as a pre-petition eighth priority claim. ${ }^{163}$

A few days after PATCO was filed, the Court of Appeals for the Eighth Circuit filed an opinion in In re L.J. O'Neill Shoe Company. ${ }^{164}$ Unlike the panel in PATCO, the $O$ 'Neill Shoe panel did not address whether taxes on prepetition income would be deemed to have been incurred post-petition. ${ }^{165}$ Like PATCO, however, the court held that

attributable to income earned prepetition receive the seventh level priority status described in Section 507(a)(7), and the taxes attributable to income earned after the petition date receive first priority administrative expense status under Section 503(b)(1)(B)." Interco, 143 B.R. at 714. The court did not indicate how the prepetition and post-petition tax liability (which, after all, is based on the application of marginal rates) should be computed. The bankruptcy court's decision in Interco was affirmed by the Court of Appeals for the 8th Circuit in In re L.J. O'Neill Shoe, 64 F.3d 1146 (8th Cir. 1995), discussed supra note 159 .

The O.P.M. court reached a similar allocation result by focusing on when the activity giving rise to the tax liability occurred. If the activity occurred prepetition, then the taxes would be covered by 507(a)(8)(A)(iii) and would not be entitled to administrative priority. If the activity giving rise to the taxes occurred after the petition date, then the taxes would be "incurred" by the estate and would be subject to administrative priority. The only authority cited by the court for focusing on the activity giving rise to the tax liability are cases involving tax years entirely prepetition or entirely post-petition. See O.P.M., 68 B.R. at $983-84$.

${ }^{161}$ Id. at 1304 ("In conclusion, we hold that $P A T C O$ 's 1988 income tax liability for income earned prior to the granting of the order for relief and the appointment of the Trustee on October 31, 1988 does not qualify as an administrative expense. Even though the taxes were "incurred by the estate" on December 31, 1988, the plain meaning of the phrase "not assessed before, but assessable, under applicable law or by agreement, after, the commencement of the case," persuades us that the 1988 tax claim fits squarely within the definition of $\S 507(\mathrm{a})(7)(\mathrm{A})(\mathrm{iii})$ and is therefore not an allowable administrative expense.”)

16211 U.S.C. $§ 503(\mathrm{~b})(1)(\mathrm{B})(\mathrm{i})$.

${ }^{163}$ An additional issue in $P A T C O$ was whether the government's priority tax claim was barred because the government's proof of claim was filed late. The panel in $P A T C O$ held that the claim was not barred because, at the time, section 502 contained no provision for disallowing claims solely because the claims were filed late. PATCO had followed the earlier holding of the Court of Appeals for the Second Circuit in In re Vecchio, 20 F.3d 555, 559 (2d Cir. 1994), that late filed priority tax claims were not barred by the Bankruptcy Code and thus could not be barred by the Bankruptcy Rules. The Court of Appeals for the Sixth Circuit rejected the analysis of the Vecchio and PATCO panels, holding that Bankruptcy Rule 3002, which requires creditors to file proofs of claim by the bar date, constitutes a separate substantive rule of law sufficient to disallow the government's late-filed priority claim. In re Chavis, 47 F.3d 818, 823 (6th Cir. 1995). The issue became moot for cases filed after Congress passed the Bankruptcy Reform Act of 1994, Pub. L. No. 103-394, § 213, 108 Stat. 4106 (1994), which added to the Bankruptcy Code a provision disallowing most late-filed claims.

16464 F.3d 1146 (8th Cir. 1995).

${ }^{165} I d$. at 1149 ("We need not accept the debtors' invitation to reach the difficult question of whether the portion of the tax attributable to prepetition income was "incurred by the estate," because like the courts below, we conclude that the prepetition portion of the claim was for a tax of a kind specified in section 507(a)(7).”). 
prepetition taxes in the year of bankruptcy are covered by the post-petition assessability rule, and are therefore excluded from discharge. ${ }^{166}$

The difficult problem for the O'Neill Shoe panel was addressing the government's argument that the court's interpretation of the post-petition assessability rule would apply it to all post-petition taxes. Like the panel in PATCO, the lower courts in O'Neill Shoe had dismissed the government's argument as "absurd." The $O$ 'Neill Shoe panel, however, expressed concern with the lower courts so easily dismissing the analogy as "absurd." 167 To solve the interpretative dilemma, the O'Neill Shoe panel noted that the other two provisions in section 507(a)(8) - the lookback rule ${ }^{168}$ and the 240 day assessment rule ${ }^{169}$ - only apply to pre-petition conduct. Even though, prior to the 2005 Act, ${ }^{170}$ the post-petition assessability rule contained no such language, the O'Neill Shoe panel suggested that Congress must have intended the post-petition assessability rule to likewise apply only to taxes on prepetition income. ${ }^{171}$ While this may be a sensible reading of Congressional intent, it is certainly not a reading mandated by the language of the statute. Unlike subsections (i) and (ii) of section 507(a)(8)(A), which specifically referred to, or could only applied to, tax liabilities for years ending prepetition, ${ }^{172}$ subsection (iii) made no such reference. The doctrine of Expresio unius est exclusio alterius $^{173}$ would lead to the opposite of the result suggested by the panel in O'Neill Shoe. ${ }^{174}$

Moreover, the O'Neill Shoe panel did not wholly incorporate the theory used in the lookback and 240 day rules. Had it done so, prepetition taxes incurred in the year of bankruptcy would not be covered by section 507(a)(8) at all, since the lookback rule and the 240 day rule only apply to taxes for years ending prepetition. ${ }^{175}$ While the O'Neill Shoe panel's partial incorporation of the lookback rule's language into the post-petition assessability rule solves the interpretative problem of entirely post-petition taxes falling within the post-petition assessability rule, full incorporation would, as discussed below

\footnotetext{
${ }^{166} \mathrm{Id}$. at 1150 .

${ }^{167}$ L.J. O'Neill Shoe, 64 F.3d at 1150 ('We nevertheless agree with MDOR [the taxing authority] that the 'plain meaning' reading provided by the lower courts presents some conceptual difficulties and structural inconsistencies in this case.").

16811 U.S.C. $\$ 507(\mathrm{a})(8)(\mathrm{A})(\mathrm{i})$.

16911 U.S.C. $\$ 507(\mathrm{a})(8)(\mathrm{A})(\mathrm{ii})$.

${ }^{170}$ The 2005 Act contains an amendment causing all three rules in section 507(a)(8) to apply only to taxes for years arising post-petition. 11 U.S.C. $§ 507(a)(8)$ (2005) (flush language).

${ }^{171}$ L.J. O'Neill Shoe, 64 F.3d at 1150 ("We believe that subsection (iii) can be read, like the other subsections of $507(\mathrm{a})(7)(\mathrm{A})$, to address only prepetition taxable activity or events.") .

${ }^{172}$ See supra notes $147-149$.

${ }^{173}$ Literally, the expression of one thing is the exclusion of others. See BLACK's LAW DICTIONARY 581 (6th ed. 1990) ("[w]hen certain . . . things are specified in a law . . . an intention to exclude all others from its operation may be inferred."). The doctrine is normally used with respect to lists, but similar reasoning would apply where one part of a statute mentions an exclusion while another part does not.

174 The argument would be that by expressing that subsection (i) only applies to taxes for years ending prepetition and not expressing a similar limitation in subsection (iii), Congress did not intend the limitation to apply under subsection (iii). See Sosa v. Alvarez-Machain, 542 U.S. 692, 741 n.9 (2004) (quoting 2A N. Singer, StATUTES AND STATUTORY CONSTRUCTION $§ ~ 46: 06$, at 194 (6th ed. 2000) ("the usual rule [is] that 'when the legislature uses certain language in one part of the statute and different language in another, the court assumes different meanings were intended." ').

${ }^{175}$ See supra notes 147 - 149.
} 
with respect to the 2005 Act, ${ }^{176}$ cause a more serious problem of excluding all taxes in the year of bankruptcy from eighth priority treatment.

Other courts have followed PATCO and O'Neill Shoe in holding that taxes owing by corporate debtors in the year of bankruptcy are to be split between the prepetition and post-petition period, with the prepetition taxes entitled to eighth priority and the postpetition taxes entitled to first priority. ${ }^{177}$ Despite the holding of three circuit courts, the Internal Revenue Service has continued to claim that all taxes incurred in the year of bankruptcy are post-petition claims entitled to first priority as administrative expenses. ${ }^{178}$

In a series of scholarly articles published in the American Bankruptcy Institute Law Review in 2001, three experts suggested various approaches for treating year-ofbankruptcy taxes in the corporate context. Professor Jacob L. Todres argued that corporate taxes in the year of bankruptcy should be apportioned between the prepetition period and the post-petition period based on time, ignoring whether the income being taxed was in fact earned prepetition or post-petition. ${ }^{179}$ Professor Todres argued that the time-based approach is consistent with the tax rules in other areas, ${ }^{180}$ and is consistent with the language of I.R.C. section 1398, which allows only individuals to make the splityear election. ${ }^{181}$ Professor Todres agrees with $P A T C O$ that all straddle-year taxes were "'incurred by the estate' since a tax is always deemed incurred on the last day of the taxable year." 182 According to Professor Todres, the PATCO result is consistent with both the Bankruptcy Code and the annual year concept of tax law. Professor Todres did not explain how some taxes deemed to arise prepetition (namely, a portion of the taxes

\footnotetext{
${ }^{176}$ See discussion infra beginning at page 41 .

${ }^{177}$ See In re Hillsborough Holdings Corp., 116 F.3d 1391, 1396 (11th Cir. 1997); In re Quid Me Broadcasting, Inc., No. 95-03876, 1996 U.S. Dist. LEXIS 7581, *14-15, 78 A.F.T.R.2d (RIA) 5039 (W.D.N.Y. 1996). See also In re Bayly Corp., 163 F.3d 1205, 1208 (10th Cir. 1998) (holding that the Pension Benefit Guaranty Corporation's claim against the debtor for under-funding its pension plan was not an obligation "incurred by the estate" within the meaning of section 503(b)(1)(B), and therefore panel did not address whether the obligation constituted a "tax." The panel suggested that it would follow OPM Leasing rather than PATCO if the obligation was a tax by treating it as "incurred" when the liability accrued rather than when the tax year ended. ) $I d$. at 1209.

${ }^{178}$ See Memorandum for Associate Area Counsel, 2002 IRS CCA LEXIS 67, *11-13 (2002) (“[o]ur position is that no provision of section 507(a)(8) includes the prepetition portion of income tax liability for the straddle year"').

${ }^{179}$ Jacob L. Todres, Tax Filing Year in Bankruptcy: Corporate Bankruptcy: Treatment of Filing Year Income Tax - A Suggested Approach, 9 AM. BANKR. INST. L. REV. 523 (2001).

${ }^{180}$ Professor Todres identifies five situations in which taxes must be apportioned: (1) an "S" corporation shareholder's interest in the corporation is terminated mid-year, (2) an " $\mathrm{S}$ " corporation's status is terminated mid-year, (3) a corporation that has gone through a change of control mid-year wishes to carryback net operating losses, but is limited by I.R.C. section 382 from carrying-back post-change-of-control losses, (4) a corporation that enters or leaves a consolidated group mid-year cannot have post-departure tax items attributed to the group's consolidated return, and (5) a partner's interest in a partnership is terminated mid-year. $I d$. at 543-545. In the first three situations, the default rule is to allocate the year-end tax items based on time, but in certain cases the parties can elect to close the tax year at the time of change. Id. The opposite rule applies in the fourth situation: the default year requires the corporation to lose the tax year at the time of change, but an election is available in certain circumstances to allocate. Id. In the fifth situation, the Internal Revenue Code allows either allocation, closing the books, or any other method of allocation that is reasonable.

${ }^{181} \mathrm{Id}$. at 549 .

${ }^{182}$ Id. at 554. Professor Todres does not consider the effect of 11 U.S.C. section 502(i) on this conclusion.
} 
from the year of bankruptcy) could come within the language of the post-petition assessability rule, while all other post-petition taxes would not.

Attorney Graham Stieglitz argued that the government's claim for taxes should be deemed to arise for bankruptcy purposes when the income giving rise to the claim was earned, rather than at the end of the year when the tax claim arises under applicable nonbankruptcy tax law. ${ }^{183}$ Stieglitz thus rejects the interpretation made by the Court of Appeals for the Ninth Circuit in PATCO and accepted by Professor Todres. Stieglitz bases his argument on the definition of a "claim" under bankruptcy law, focusing on a series of famous bankruptcy law tort cases that struggled with the question of whether the claimant had a right to payment on the petition date. ${ }^{184}$

Professor Jack F. Williams summarized the two other articles, and suggested that Congress decide whether income taxes incurred by a corporation in the year of bankruptcy should be entirely treated as administrative expenses, should be divided between the prepetition and post-petition periods based on mandating the filing of separate returns, or should be allocated on the basis of time. ${ }^{185}$

Thus, under existing law, there is a split of opinion as to whether the government's claim for taxes on prepetition corporate income should be deemed to have been incurred prepetition or post-petition. Regardless of the answer to this question, however, every court to consider the issue has held that the claim for such taxes is not entitled to administrative expense priority because the post-petition assessability rule applies and relegates the taxes to eighth priority. The Internal Revenue Service has never accepted the case law, and has continued to insist that corporate tax claims in the year of bankruptcy be treated as first priority administrative expenses. ${ }^{186}$

Similarly, none of the cases has directly ruled on how the taxes incurred in the year of bankruptcy are to be apportioned between the prepetition and post-petition periods. Professor Todres has correctly identified two possible apportionment methods the "closing of the year" method in which the tax liability for transactions which occurred prepetition would be determined separately from the tax liability for transactions which occurred post-petition, and the allocation-based-on-time method in which the final year of bankruptcy tax liability is apportioned based on the length in time in the prepetition and post-petition periods. ${ }^{187}$ The former method would be inconsistent with the Internal Revenue Code's theory excluding corporations from making a split year election, because the allocation would require the taxpayer to prepare two tax returns to identify the tax effect of the income earned prepetition. Therefore, apportionment based on time is more consonant with the statutory rules. Apportionment based on time also answers the government's argument that any apportionment would treat corporate taxpayers as if they

\footnotetext{
${ }^{183}$ Graham Stieglitz, Mini-Symposium: Tax Filing Year in Bankruptcy: Stuck in the Middle Again! How to Treat Straddle-Year Income Taxes in a Corporate Chapter 11 Reorganization, 9 AM. BANKR. INST. L. REV. 467 (Winter 2001).

${ }^{184}$ The bankruptcy court's definition of a "claim" is discussed infra beginning at note 218 . A stronger argument in favor of Mr. Stieglitz's view can be made by focusing on contract cases, which are more directly relevant to tax liabilities than are the tort cases upon which Stieglitz relies. Id.

${ }^{185}$ Jack F. Williams, Mini-Symposium: Tax Filing Year In Bankruptcy: Bifurcation for Claim Filing Purposes of a Corporate Tax Year That Straddles the Petition Date, 9 AM. BANKR. INST. L. REV. 463 (Winter 2001).

186 See supra note 178.

187 See discussion supra notes 179 - 182.
} 
were eligible to make the split-year election. Unlike a split-year election, apportionment based on time does not attempt to account separately for prepetition and post-petition activity. For example, a non-electing debtor who filed bankruptcy at the end of March, and owed $\$ 10,000$ in taxes for full calendar year would owe one-quarter of the taxes $(\$ 2,500)$ for the pre-petition period, and three-quarters of the taxes $(\$ 7,500)$ for the postpetition period. The government would have a $\$ 2,500$ claim entitled to eighth priority under section 507(a)(8)(A)(iii), and a \$7,500 claim entitled to first priority as an administrative expense. This would be true even if all of the activity giving rise to the tax occurred prepetition. Under the closing-of-the-year method, all of the taxes in this event would be subject to eighth priority, and none would be eligible for treatment as first priority administrative expenses. An allocation based on time would harmonize the statutory provisions while making an appropriate distinction between creditors who make a split year election (and thus allocate pre- and post-petition taxable activity), and those who do not make the election.

While allocating year-of-bankruptcy taxes based on time best harmonizes the existing statutory rules, Congress should consider changing the law to require all taxpayers to split the year of bankruptcy into two taxable years. There would be significant advantages to mandating a split-year return. Most importantly, a split-year return would eliminate confusion as to the amount and treatment of prepetition and postpetition claims. The existing system, which allows individual taxpayers in Chapter 7 and 11 cases to elect whether they wish to split their returns or not, likely results in lower tax revenues, because debtors can be expected to make the election only when it will reduce their tax liabilities. Similarly, if prepetition and post-petition claims are prorated on the basis of time, the claim amounts will not properly reflect prepetition and post-petition economic activity. The only disadvantage of requiring a split-year election is that debtors will be required to do the extra work of preparing two partial-year tax returns. Under existing law, individual taxpayers are already strongly incentivised to make the split-year election, ${ }^{188}$ and all taxpayers must prepare segregated prepetition and post-petition financial records in order to comply with the rules of bankruptcy procedure. ${ }^{189}$ Therefore, the additional expense from mandating a short-year tax return would likely not be very significant. On balance, mandating a split-year return makes the most sense because it would accurately tax and treat prepetition and post-petition activities, would minimize manipulation, and would not impose an undue burden on taxpayers who are already required to maintain segregated financial records. By mandating separate tax returns for the prepetition and post-petition period, the priority given to the government's claims would accurately reflect the debtor's economic activity, would limit opportunities for tax manipulation, and would not impose a significant hardship on debtors..

\section{ii. Individual Taxpayers Who Do Not Make The Split- Year Election.}

\footnotetext{
${ }^{188}$ See discussion infra beginning at note 245.

${ }^{189}$ See, e.g. Bankruptcy Rule 1007(b)(1) (debtor must file schedules of assets, liabilities, current income and expenditures; 2015(a) (requiring debtors to file, among other things, monthly operating reports and reports of disbursements); 11 U.S.C. $\$ 704(8)$ (required monthly operating reports).
} 
The courts have applied an entirely different set of rules to individual debtors who do not make the split-year election. Instead of holding that the prepetition taxes are entitled to eighth priority under the post-petition assessability rule, ${ }^{190}$ the courts have consistently held that the prepetition taxes do not constitute a claim against the estate at all, and the debtor is solely liable for them. ${ }^{191}$ The courts considering this issue have relied on a statement in a committee report to the Bankruptcy Tax Act of 1980, which suggests that the entire tax liability for the year of bankruptcy is to be treated outside of bankruptcy, and should not be a liability of the estate: "If the debtor does not make the [section 1398 split-year] election, no part of the debtor's tax liability from the year in which the bankruptcy case commences is collectible from the estate, but is collectible from the individual debtor." 192 Many courts have followed this legislative history in holding that the bankruptcy estate has no liability for taxes of an individual debtor incurred in the year of bankruptcy if the debtor does not make the split-year election. ${ }^{193}$

\footnotetext{
${ }^{190} 11$ U.S.C. $\$ 507(\mathrm{a})(8)(\mathrm{A})(\mathrm{iii})$.

${ }^{191}$ See, e.g. In re Haedo, 211 B.R. 149, 152 (S.D.N.Y. 1997) (if debtor does not make the split-year election "the entire liability for the year of the bankruptcy filing is a claim against the debtor but is not collectible from the estate"); In re Prativadi, 281 B.R. 816, 819 (Bankr. W.D.N.Y. 2002); In re Johnson, 190 B.R. 724, 726 (Bankr. Mass. 1995) ("The Debtors' failure to make the election under section 1398 leaves the IRS with a post-petition tax claim against the Debtors individually, with no claim whatsoever against their bankruptcy estate for any part of the 1992 tax liability"); In re Pflug, 146 B.R. 687, 689 (Bankr. E.D. Va. 1992); In re Moore, 132 B.R. 533 (Bankr. W.D. Pa. 1991); In re Mirman, 98 B.R. 742, 744-745 (Bankr. E.D. Va. 1989); In re Turboff, 93 B.R. 523, 525 (Bankr. S.D. Tex. 1988); see also In re Canon, 130 B.R. 748, 751 (Bankr. N.D. Tex. 1991) ("The United States contends that the Trustee is not entitled to the 1988 refund because the estate has no liability for the Debtor's 1988 taxes. However, liability for unpaid taxes is not at issue here because withholdings made both prepetition and post-petition satisfied the tax liability for the year in which the Debtor filed his Chapter 7 petition. Furthermore . . . a trustee has a right to demand an apportioned share of the refund if the debtors are entitled to a refund for the tax year in which the petition is filed.”); accord In re Weir, No. 85-40456-7, 1990 Bankr. LEXIS 778, *9, 71 A.F.T.R.2d (RIA) 4724 (Bankr. D. Kan. 1990).

However, in In re Wood, 240 B.R. 609 (C.D. Cal. 1999), the district court applied a different rule in a Chapter 11 case. First, the Wood court stated in accordance with the other cases involving non-electing individuals that the prepetition taxes for the year of bankruptcy would not constitute a claim against the estate. The debtor argued that since the taxes were due prior to the confirmation of the plan, and the government had failed to obtain payment through the plan, the taxes were dischargeable in Chapter 11. To avoid having the taxes be discharged, the court first suggested that the taxes would be entitled to first priority treatment as administrative expenses, and thus would be excepted from discharge. "There is no question that the tax liability would be a nondischargeable debt. See 11 U.S.C. § 523(a)(1)(A)." Id at 613 n.36. The two rulings conflict with each other. If the estate is not liable for the taxes, then the taxes cannot constitute administrative expenses. To be administrative expenses, the taxes must be "incurred by the estate." See 11 U.S.C. § 503(b)(1)(B)(i). Moreover, administrative expenses are not excepted from discharge under Chapter 7 or Chapter 11. See 11 U.S.C. $\S \S 523(a)(1)(B)$ (covering only "taxes entitled to priority under 507(a)(8)); $\S 1141$ (discharge of claims arising priority to confirmation, except taxes of an individual excepted from discharge under section 523(a)). The court used conclusionary language to obfuscate the statutory rules in order to prevent the debtor from discharging under Chapter 11 taxes that would not be dischargeable under Chapter 7. A consistent application of the rule stated in the legislative history - that the taxes are not an obligation of the estate, but instead are a personal obligation of the debtor arising at the end of the tax year - should have resulted in the discharge of the taxes not dealt with under the plan.

${ }^{192}$ S. Rep. No. $96-1036$ at 26, $1980-2$ C.B. 620 , quoted in In re Prativadi, 281 B.R. 816, 819 (Bankr. W.D. N.Y. 2002); In re Johnson, 190 B.R. 724, 727 (Bankr. Mass 1995). This was the Senate Report issued in connection with the Bankruptcy Tax Act of 1980, Pub. L. 96-589, 94 Stat. 3389.

${ }^{193}$ See supra note 191.
} 
The court's treatment of prepetition taxes in the year of bankruptcy is wrong for a number of reasons. First, the courts have treated this legislative history as if it were itself law, without explaining how this result can be reached under the existing statutory provisions. Indeed, there is no solid basis under the existing statutory rules for the disparate treatment of corporations and individuals who do not make the split-year election with respect to prepetition taxes. Individuals in Chapter 7 and 11 cases who do not make the split-year election, and individuals in Chapter 12 and 13 cases and corporations who are ineligible to make the split year election, are treated as having their taxable year determined without regard to the filing of the bankruptcy case. ${ }^{194}$ The only difference between the treatment of non-electing individuals and corporations is that there is cleavage between an individual debtor and the estate in Chapter 7 and 11 cases as to post-petition taxes, ${ }^{195}$ while there is no cleavage between individual debtors in Chapters 12 and 13 and corporate debtors on the one hand, and the estate on the other hand, as to post-petition taxes. ${ }^{196}$ This is because there is no separate identity between a Chapter 12, Chapter 13 or corporate debtor and the estate, while there is a separate identity between an individual debtor in Chapter 7 and 11 and the estate. ${ }^{197}$ An individual receives a fresh start under Chapter 7 and 11, and may thus have income and deductions separate from the estate. A corporation (or an individual in Chapter 12 or 13), on the other hand, has no separate existence. While there is a basis for different treatment of post-petition obligations, nothing in the statute ${ }^{198}$ requires special treatment for nonelecting individual Chapter 7 or 11 taxpayers with respect to prepetition items.

Second, the language in the cited legislative history could be applied equally to corporations who do not make the split-year election (because they are ineligible to do so) and individuals who are eligible but choose not to elect.

Third, disallowing a claim against the estate for prepetition taxes is bad policy. The prepetition income that is being taxed (to the extent it has not been dissipated) is property of the estate. Disallowing a claim against the estate puts the government at a disadvantage vis à vis other unsecured creditors in recovering a distribution from the estate. In Chapter 7 cases, the government might not care about losing a claim against the estate because the debtor remains personally liable for payment of the taxes because only prepetition "claims" are discharged, ${ }^{199}$ and by definition the tax liability is not being treated as a prepetition "claim." However, the government could well suffer a loss if the debtor had no post-petition assets or non-exempt earnings from which to pay the taxes.

Fourth, disallowing a claim against the estate creates confusion under the Chapter 11 discharge. The discharge under Chapter 11 applies to claims against the debtor arising

\footnotetext{
${ }^{194}$ See I.R.C. $\$ 1398(d)(1)$.

195 See I.R.C. $\S 1398(\mathrm{e})$.

${ }^{196}$ I.R.C. $\S 1399$.

${ }^{197}$ See In re Knobel, 167 B.R. 436, 443 (Bankr. W.D. Tex. 1994), citing H.R. Rep. No. 96-833 at 19 n.2 (1980) ("The individual may obtain new assets or earn wages after transfer of the pre-bankruptcy property to the trustee and thus derive income independent of that derived by the trustee from the transferred assets of the bankruptcy estate as in chapter 7 and exempt property may be used to make payments to creditors, and hence the bankruptcy law does not create the same dichotomy between after-acquired assets of the individual debtor and assets of the bankruptcy estate as in chapter 7 or chapter 11 cases.").

${ }^{198}$ I.R.C. § 1398; 1399.

199 See 11 U.S.C. $§ 727$ (b) (discharge applies to prepetition "debts," which are defined in section 101(12) as liability on a "claim.").
} 
prior to the date that the plan of reorganization was confirmed (and thus includes postpetition claims arising prior to confirmation). ${ }^{200}$ If, as the cases hold, the government has no prepetition “claim" against a non-electing individual debtor's bankruptcy estate, ${ }^{201}$ and, furthermore, the government is not entitled to an administrative expense priority because the taxes were not "incurred by the estate," 202 then the debtor should be able to discharge the post-petition non-priority taxes under a plan of reorganization. ${ }^{203}$ Surely, such a result was not intended.

Presumably, the courts would support their decision disallowing any tax claim against the estate of a non-electing individual debtor for the year of bankruptcy by arguing that the statute says that the debtor has a single tax year, and that under applicable non-bankruptcy tax law the claim for taxes is deemed to have been "incurred" at the end of the year - post-petition. ${ }^{204}$ Because the "claim" is deemed to arise postpetition, no claim is allowed under section 502. Although there is nothing in the Tax Code itself that says that taxes are deemed to have been "incurred" at the end of the tax year, it is of course true that a year's tax liability cannot be determined until the year is completed. $^{205}$ The corporate cases have not been consistent in determining when taxes are incurred. In support of its conclusion that taxes for the year of bankruptcy were

${ }^{200} 11$ U.S.C. $\S 1141(\mathrm{~d})(1)(\mathrm{A})$.

${ }^{201}$ See supra note 191.

${ }^{202}$ See 11 U.S.C. $\S 303(b)(1)(B)$.

${ }^{203}$ For example, assume a debtor files bankruptcy in June, 2005, and owes $\$ 60,000$ in taxes for the 2005 year, half of which was attributable to prepetition income. If the debtor is able to confirm a plan in December 2006 that provides for $20 \%$ distribution to unsecured creditors, can the debtor discharge the $\$ 30,000$ prepetition tax liability by paying only $\$ 6,000$ ? It would appear under the courts' rulings that the government has no prepetition claim against the estate on account of taxes on income earned prepetition. Similarly, none of the taxes on prepetition income was incurred "by the estate," since the estate did not exist prepetition, and thus the government would not be entitled to recover administrative expenses on account of the prepetition taxes. Since the government is not entitled to a priority claim, it would appear that the liability could be discharged under Chapter 11 - something Congress certainly did not intend.

There are several coherent ways around the problem, however. Under the so-called "best interests of creditors" test, the plan can be confirmed only if non-accepting creditors receive at least as much in value as they would receive in a Chapter 7 liquidation occurring on the effective date of the plan. 11 U.S.C. $§ 1129(\mathrm{a})(7)(\mathrm{A})(\mathrm{ii})$. If a new Chapter 7 case were to be filed on the effective date of the plan, the prepetition taxes would be entitled to priority under 507(a)(8) (since the claim would have arisen prepetition), and thus the creditor would be entitled to full payment of the claim (albeit over six years). Thus, by making no distribution on account of the claim, the plan fails the best interests of creditors test. Alternatively, the court could find that the plan fails the good faith tests. 11 U.S.C. § 1129(a)(2), (a)(3). The courts that have considered this issue have simply ruled that the plan could not be confirmed without paying the claims in full. See In re Johnson, 190 B.R. 724, 728 (Bankr. Mass. 1995); In re Wood, 240 B.R. 609,613 (C.D. Cal. 1999) (stating, without any analysis, that "There is no question that the tax liability would be a nondischargeable debt" under 11 U.S.C. § 523(a)).

${ }^{204}$ Interestingly, some of the courts applying the legislative history in the individual context have rejected the notion that the prepetition taxes in the year of bankruptcy were incurred at the end of the year. See In re Johnson, 190 B.R. at 726 ("Although the term "incurred" is not defined by the Bankruptcy Code, the clear weight of authority holds that federal income taxes are incurred at the time they accrue as opposed to the time payment is due for section 503(b)(1)(B) purposes.").

${ }^{205}$ See Todres, supra note 179, at 533 ("From a tax standpoint, it normally makes no sense to attempt to determine how much tax was incurred in a portion of the tax year, since the tax consequences are dependent upon what happens during the remainder of the taxable year"); PATCO, 64 F.3d at 1299 (noting that "the statutory language is unclear [as to when a tax claim arises, so] we look to legislative history to glean Congress' intent”). 
"incurred" on the last day of the tax year, the Court of Appeals for the Ninth Circuit in PATCO relied on statements about the proposed Bankruptcy Act of 1978 made by the House and Senate managers after the conference amendments were completed. ${ }^{206}$ These statements reflected language contained in the Senate Finance Committee's report on an earlier draft of the bill, which included a provision specifying that income taxes were to be deemed "incurred" for bankruptcy purposes at the end of the tax year. ${ }^{207}$ The Senate Finance Committee's language to which the statements referred was deleted at the conference level and did not become part of the Bankruptcy Code. ${ }^{208}$ The PATCO panel relied on the statements as if the deletion was an oversight. With equal force, one could argue that the deletion of this language suggests an intent by Congress that the taxes not be treated as "incurred" at the end of the tax year. There is simply no clear authority for treating prepetition taxes in the year of bankruptcy as being "incurred" at the end of the year. ${ }^{209}$ Indeed, the majority of the courts to consider the issue have rejected the PATCO panel's analysis by holding that taxes are "incurred" as they accrue. ${ }^{210}$

Interestingly, the court in In re Johnson, ${ }^{211}$ one of the cases following the legislative history by disallowing any claim against the bankruptcy estate for taxes owing by a non-electing individual, ${ }^{212}$ held that taxes are incurred as they accrue (rather than at the end of the year). The debtor in Johnson filed a petition under the reorganization provisions of Chapter 11, and did not make the split-year election. The debtor sought to treat the prepetition taxes owing for the year of bankruptcy as eighth priority taxes under the post-petition assessability rule, rather than as first priority administrative expenses, because debtor could confirm a plan to pay eighth priority taxes over six years, ${ }^{213}$ while the debtor would have had to pay first priority administrative expenses in cash on the

\footnotetext{
${ }^{206}$ PATCO, 64 F.3d at 1300.

${ }^{207}$ S. 2266, 95th Cong., 2d Sess., § 346(a) (1978) (as reported by the Senate Judiciary Committee and the Senate Finance Committee), reprinted in Collier on Bankruptcy, Appendix Volume 3 at VII (15th ed. 1995) ("[A] tax on or measured by income or gross receipts for a taxable period shall be considered incurred on the last day of the taxable period.").

${ }^{208}$ PATCO, 64 F.3d at 1300.

${ }^{209}$ In a so-far unsuccessful attempt to obtain first priority administrative expense treatment for corporate taxes incurred in the year of bankruptcy, the government has consistently argued that taxes are incurred at the end of the tax year. See supra note 178. As is discussed below, if the government's argument is successful but the taxes are not accorded administrative expense priority under applicable bankruptcy, the government will be relegated to having a dischargeable general unsecured claim.

${ }^{210}$ See, e.g. In re Redmond, 36 B.R. at 934 ("For purposes of determining when the taxes were incurred, it is the date the taxes accrued rather than the date of assessment which controls."); In re Hillsborough Holdings Corp., 156 B.R. at 320, aff'd on other grounds, 116 F.3d 1391 (11th Cir. 1997); In re O.P.M. Leasing Services, Inc., 68 B.R. 983-84 ; see also In re Interco, Inc., 143 B.R., 714 ("Congress . . directed that certain claims which were technically incurred post-petition should nevertheless be excluded (at least in part) from first level priority status to reflect their prepetition connections.").

${ }^{211}$ In re Johnson, 190 B.R. at 726.

212 Because the claim was not dischargeable, the court held that the debtor was required to pay the claim in full under the plan (even though the government had no claim against the debtor's estate). Johnson, 190 B.R. at 728 ("'[T]his Court finds that the Debtors' 1992 tax liability to the IRS can only be collected from the Debtors or from their post-petition income for services performed after the filing of the Chapter 11. Moreover, the Debtors' Chapter 11 plan must provide for payment of these taxes, as their payment is integral to the feasibility and good faith requirements of 11 U.S.C. $\$ 1129$.”) (citations omitted).

${ }^{213} 11$ U.S.C. $\S 1129(\mathrm{a})(9)(\mathrm{C})$ (repealed 2005). Under the 2005 Act, eighth priority taxes must be paid in regular installments over five years following the date the petition was filed, unless the debtor treats other nonpriority unsecured creditors in a more favorable way. See 11 U.S.C. $\S 1129(a)(8)(C)(2005)$.
} 
effective date of the plan. ${ }^{214}$ The Johnson court agreed with the debtor that the taxes were "incurred" as they accrued, but rejected the argument that the taxes therefore were covered by the post-petition assessability rule. The Johnson court held instead that the split year election rules somehow mandate that the taxes incurred in the year of bankruptcy not constitute a claim against the estate. ${ }^{215}$ The Johnson court did not explain why treating the prepetition taxes as eight priority claim would thwart the split-year election rules. Presumably, the court believed that granting an eighth priority would treat electing and non-electing debtors the same way - a belief that is not well grounded. ${ }^{216}$ Ultimately, the Johnson court held that the taxes were personal obligations of the debtor that could not be restructured under the plan. The Johnson court did not consider that its ruling would appear to make the taxes dischargeable, since confirmation of a Chapter 11 plan discharges all claims against the debtor arising prior to the confirmation date and not dealt with by the plan. ${ }^{217}$

More importantly, the Johnson court's analysis wrongly focuses entirely on the label attached to the claim by the tax law, and ignores the Bankruptcy Code's definition of a "claim." A "claim" is broadly defined in the Bankruptcy Code to include any right to payment, even if unliquidated, contingent and unmatured. ${ }^{218}$ The legislative history says that Congress intended this language to be interpreted in the broadest possible way. ${ }^{219}$ While applicable non-bankruptcy law determines whether a claimant has a substantive right to payment, the timing of the claim for bankruptcy purposes is a question of federal bankruptcy law, and is not governed by the label attached to the claim by non-bankrutpcy law. ${ }^{220}$ In tort cases, some courts have focused exclusively on

\footnotetext{
${ }^{214}$ See 11 U.S.C. $\S 1129(\mathrm{a})(9)(\mathrm{A})$.

${ }^{215}$ Johnson, 190 B.R. at 727 ("the cases cited by the Debtors [for the proposition that the prepetition taxes in the year of bankruptcy fall within the post-petition assessability rule] are corporate cases, not individual cases, or do not involve income taxes, and section 1398 is inapplicable to corporations. The allocation scheme advocated by the Debtors circumvents their failure to make the election afforded them by section 1398(d)(2). Therefore, in the context of Chapter 7 and Chapter 11 cases involving individual debtors, such an allocation scheme contravenes the provisions of the Tax Reform Act.").

${ }^{216}$ See discussion supra after note 187.

${ }^{217} 11$ U.S.C. $\S 1141(\mathrm{~d})(1)(\mathrm{A})$ (Confirmation of a plan "discharges the debtor from any debt that arose before the date of such confirmation.").

21811 U.S.C. $\$ 101(\mathrm{a})(5)(\mathrm{A})$.

${ }^{219}$ See H.R. REP. NO. 95-595 at 309 (1978), reprinted in 1978 U.S.C.C.A.N. 5963, 6266; S. Rep. No. $95-$ 989 at 21-2 (1978), reprinted in 1978 U.S.C.C.A.N. 5787, 5807-08 ("By the broadest possible definition and by the use of the term throughout [the Bankruptcy Code] . . . the bill contemplates that all legal obligations of the debtor, no matter how remote or contingent, will be able to be dealt with in the bankruptcy case. It permits the broadest possible relief in the bankruptcy court.")

${ }^{220}$ See Ralph R. Mabey \& Annette W. Jarvis, In re Frenville: A Critique by the National Bankruptcy Conference's Committee on Claims and Distributions, 42 Bus. LAW. 697, 704 (1987) ("state law labels established for an entirely different purpose should not be determinative of when a claim arose for purposes of its treatment in bankruptcy," citing Thomas A. Jackson, THE LOGIC AND LIMITS OF BANKRUPTCY LAW 48-49 (1986)). Only the Third Circuit has suggested that state law labels of when a claim "accrues" should be controlling in Bankruptcy. In the now infamous case of In re M. Frenville Co., 744 F.2d 332, $335-36$ (3rd Cir. 1984), cert. denied, 469 U.S. 1160 (1985), the panel held that an accounting firm could not assert an equitable indemnity claim against the debtor for providing the accounting firm with false information until a claim giving rise to indemnity is brought against the accounting firm. The panel also held that because the indemnity "claim" did not arise under state law prepetition, the accounting firm was not prevented by the automatic stay (11 U.S.C. $\$ 362(a)$ ) from suing the debtor. The Third Circuit has continued to apply Frenville despite severe criticism from academics and other circuits. See Jones v.
} 
whether the conduct giving rise to the claim occurred prepetition. ${ }^{221}$ Most courts have required a showing that the conduct giving rise to the claim occurred prepetition, and that a sufficient relationship existed between the claimant and the debtor/tortfeasor so that it would be fair to expect the debtor to discover the injury and file a proof of claim in the bankruptcy case. ${ }^{222}$ Attorney Graham Stieglitz has concluded that the government has a "claim" for taxes owing prepetition in the year of bankruptcy under either the conduct test or the relationship test. ${ }^{223}$

While the tort cases are instructive, possibly of more relevance are the contract cases. A bankruptcy "claim" is deemed to arise in contract cases when the contract is entered into, even though no breach has occurred and even though the damages from a future breach would be difficult to determine. In a famous case under the reorganizations provisions of Section 77B of the Bankruptcy Act of $1898,{ }^{224}$ the debtor had guaranteed that its affiliated corporations would perform their obligations under long-term real property leases. The issue in the case was whether landlords had "claims" against the debtor under the guarantees when the tenants were not in default at the time of bankruptcy, and might never default. The Court of Appeals for the Second Circuit recognized that in a regular liquidation proceeding under the 1989 Act, the creditors would not have had prepetition dischargeable claims, because in liquidation proceedings under the 1898 Act claims had to be "provable," and unliquidated claims were not

Chemetron Corp., 212 F.3d 199, 206 (3rd Cir. 2000) ("[T]his court held [in Frenville] that in most circumstances a "claim" arises for bankruptcy purposes at the same time the underlying state law cause of action accrues. We are cognizant of the criticism the Frenville decision has engendered, but it remains the law of this circuit.")

Courts in all of the other circuits have either specifically rejected Frenville or have adopted theories inconsistent with Frenville. See, e.g., In re Parker, 313 F.3d 1267, 1269 (10th Cir. 2002) (rejecting Frenville); In re Jastrem, 253 F.3d 438, 442 (9th Cir. 2001) (rejecting Frenville); In re Andrews, 239 F.3d 708, 710 n.7 (5th Cir. 2001) ("The Third Circuit has taken a narrower view of "claim," but this approach has been universally rejected.") (citation to Frenville omitted); In re Manville Forest Prods., 209 F.3d 125, 129 (2d Cir. 2000) (claim will be deemed to have arisen pre-petition if "the relationship between the debtor and the creditor contained all of the elements necessary to give rise to a legal obligation - 'a right to payment' - under the relevant non-bankruptcy law"); Butler v. NationsBank, N.A., 58 F.3d 1022, 1029 (4th Cir. 1995) ("we have explicitly declined to follow the reasoning of Frenville, stating, "We have found no court outside the Third Circuit which has followed the reasoning and holding of Frenville, "citing Grady v. A.H. Robins Co., 839 F.2d 198, 201 (4th Cir.), cert. dismissed, 487 U.S. 1260 (1988)); In re Piper Aircraft Corp., 58 F.3d 1573, 1576 n.2 (11th Cir. 1995) (rejecting Frenville); In re Hemingway Transp., 954 F.2d 1, 8 (1st Cir. 1992) ("more recent decisions consistently have declined to accept the Frenville reasoning and its failure to accord full breadth to the term "claim"); Signature Combs, Inc. v. United States, 253 F. Supp. 2d 1028, 1033-34, 1038 (W.D. Tenn. 2003) (rejecting Frenville); Am Int'l v. Datacard Corp., 146 B.R. 391, 405-06 (N.D. Ill. 1992) (rejecting Frenville); In re Transp. Sys. Int'l, 110 B.R. 888, 894 (D. Minn. 1990) (rejecting Frenville).

${ }^{221}$ See Grady, 839 F.2d 198 at 201 n.4 (plaintiff who used defective Dalkon Shield manufactured by debtor pre-petition had a "claim" in bankruptcy even though plaintiff did not know she was sick at time of bankruptcy).

${ }^{222}$ See, e.g., Fogel v. Zell, 221 F.3d 955 (7th Cir. Ill. 2000); Piper Aircraft Corp., 58 F.3d at 1577 ("an individual has a $\S 101(5)$ claim against a debtor manufacturer if (i) events occurring before confirmation create a relationship, such as contact, exposure, impact, or privity, between the claimant and the debtor's product; and (ii) the basis for liability is the debtor's prepetition conduct"); In re Parks, 281 B.R. 899, 90203 (Bankr. E.D. Mich. 2002).

${ }^{223}$ See Stieglitz, supra at note 183, 9 AM. BANKR. INST. L. REV at 484-490.

${ }^{224}$ In re Radio-Keith-Orpheum, 106 F.2d 22 (2nd Cir. 1939). 
"provable." 225 However, claims that existed as of the petition date were dischargeable under the reorganization provisions of Section 77B of the 1898 Act, even though they were not provable. $^{226}$ The Second Circuit panel held that the claim arose when the contract was entered into, even though the claim was not ripe under applicable nonbankruptcy law. ${ }^{227}$ The Bankruptcy Code incorporated a definition of a "claim" similar to the definition used in Section 77B of the 1898 Act. $^{228}$ It is generally accepted now that contract claims are deemed to arise for bankruptcy purposes when the contract was executed. $^{229}$

Tax liability is more like contract liability than tort liability. The debtor knows when it earns income that it will have to pay taxes on that income. A known obligation to pay taxes on the income exists when the income is earned, even though the amount of tax may depend on future events, and the due date for payment is in the future. These factors simply mean that the tax claim is unliquidated and unmatured. But the obligation to pay has been incurred when the income is earned: the fact triggering tax liability (the incurrence of income) had incurred, and the taxpayer is aware of the obligation to pay taxes on earned income. Although the obligation to pay is set by law rather than contract, the contract cases are more apt because the obligation to pay becomes fixed when the income is earned, and does not depend on future events or discovery to ripen into an obligation. The difficult problems in tort cases - the existence of harm caused by the tort and the fairness of requiring the victim to identify both the injury and the identity of the tortfeasor at the time of bankruptcy - do not exist with respect to income taxes. The taxpayer knows upon earning income of the obligation to pay taxes, and knows to whom the taxes will be owed. Because the government has an unliquidated and unmatured right to payment when the income is earned, a claim exists for bankruptcy purposes and should be respected. Treating a tax claim on income earned prepetition as if it arose post-

\footnotetext{
${ }^{225} \mathrm{Id}$. at 26 ("The claims based on the debtor's guaranties were wholly contingent and indeterminate in amount, there having been no default under the leases and no predictable prospect of a default. In ordinary bankruptcy such claims would not be provable or dischargeable to any extent. In re F. \& W. Grand 5-10-25 Cent Stores, 2 Cir., 70 F.2d 691.").

${ }^{226} I d$. ("In a proceeding under section 77B, however, they are claims subject to reorganization. . . .

"'[C]reditors' shall include for all purposes of this section and of the reorganization plan, its acceptance and confirmation, all holders of claims of whatever character against the debtor or its property ... whether or not such claims would otherwise constitute provable claims under this title.")

${ }^{227}$ Radio-Keith-Orpheum, 106 F.2nd at 26.

${ }^{228} 11$ U.S.C. $\S 101(\mathrm{a})(5)(\mathrm{A})$ ("The term 'claim' means . . . right to payment, whether or not such right is reduced to judgment, liquidated, unliquidated, fixed, contingent, matured, unmatured, disputed, undisputed, legal, equitable, secured or unsecured.") .

${ }^{229}$ See In re Manville Forest Prod. Corp., 209 F.3d at 129 ("Under contract law, a right to payment based on a written indemnification contract arises at the time the indemnification agreement is executed"); In re Houbigant, Inc., 188 B.R. 347, $358-59$ (Bankr. S.D.N.Y. 1995) ("[A] contractual indemnification claim exists as a contingent claim against the indemnitor as of the date the indemnification agreement is executed."); see also In re Hemingway Trans., Inc., 954 F.2d 1, 9 n.9 (1st Cir. 1992); see also In re M. Frenville Co., 744 F.2d at 336 (3d Cir. 1984) (In distinguishing equitable indemnity claims from contractual indemnity claims, the panel stated: "Such a surety relationship is the classic case of a contingent right to payment under the Code -- the right to payment exists as of the signing of the agreement, but it is dependent on the occurrence of a future event. When parties agree in advance that one party will indemnify the other party in the event of a certain occurrence, there exists a right to payment, albeit contingent, upon the signing of the agreement"); In re Hemingway Transport, Inc., 954 F.2d 1, 9 n.9 (1st Cir. 1992).
} 
petition at the end of the tax year does violence to the principles underlying the bankruptcy claims process.

Finally, most courts have failed to consider the purpose of section 502(i). ${ }^{230}$ Section 502(i) says that tax claims that are deemed to "arise" post-petition, and are entitled to priority under section 507(a)(8), are to be treated for allowance or disallowance as if they had arisen prepetition. ${ }^{231}$ Section 502(i) was intended to cover tax claims for prepetition activities that are not deemed to "arise" until post-petition. ${ }^{232}$ The prepetition portion of the government's income tax claim for the year of bankruptcy is entitled to priority under section 507(a)(8)(A)(iii), because the taxes are assessable postpetition. ${ }^{233}$ Prior to the 2005 Act, ${ }^{234}$ Section 502(i) should have treated the government's claim for the prepetition portion of year-of-bankruptcy taxes as an allowed prepetition claim, even though the taxes technically may have arisen under applicable nonbankruptcy law post-petition - at the end of the tax year.

However, the only court to consider the effect of section 502(i) in this context, In re Mirman, ${ }^{235}$ held that section 502(i) should be ignored because it is contrary to the statement in the committee report that the government should have no claim against the estate of a taxpayer who does not make the split year election for year-of-bankruptcy taxes. $^{236}$ In essence, the court held that a statement from a committee report trumps the plain wording (and the legislative history) of the statute.

While the proper role of legislative history in judicial decision making has been the subject of substantial debate, ${ }^{237}$ the Supreme Court has made it clear that statements

\footnotetext{
${ }^{230}$ The only court to consider 502(i) in connection with a non-electing individual debtor is In re Mirman., 98 B.R. 742 (Bankr. E.D. Va. 1989), discussed infra note 235.

${ }^{231} 11$ U.S.C. $\$ 502(\mathrm{i})$.

${ }^{232}$ See In re St. Louis Freight Lines, Inc., 45 B.R. at 549 (following Collier on Bankruptcy's suggestion that section 502(i) was intended to cover only prepetition taxes that are assessed post-petition); In re Razorback Ready-Mix Concrete Co., 45 B.R. at 925; see also In re Miller, 363 F.3d at 1009, discussed supra beginning at note 119 (suggesting that the Victor court's analysis ignores the plain meaning of section 502(i), which is to treat a prepetition tax claim which is deemed to arise post-petition under applicable non-bankruptcy law as an allowed prepetition claims).

${ }^{233}$ See discussion supra beginning at note 132 .

${ }^{234}$ Under the 2005 Act, eighth priority will only be given to tax claims for years that end prepetition. See 11 U.S.C. § 507(a)(8) (flush language) (2005). Therefore, the only tax claims in the year of bankruptcy that can possibly be eligible for eighth priority treatment will be the prepetition portion of taxes owing by an individual debtor who makes a split-year election, and taxes owing by debtors who file bankruptcy on the last day of the tax year. In both cases, the taxes will arise prepetition not post-petition, and therefore 502(i) will not be needed. It therefore appears that section 502(i) has been turned into dead wood with respect to income taxes.

23598 B.R. 742 (Bankr. E.D. Va. 1989).

${ }^{236}$ Id. at 745 (holding that section 502(i) only applies if the debtor makes the split-year election. Note, however, that section 502(i) would not apply to the prepetition claim against a debtor who makes the splityear election, because the tax claim for the prepetition portion of the year would arise pre-petition, not postpetition).

${ }^{237}$ For some time, the justices of the Supreme Court have debated the proper role of legislative history in judicial decision making. For example, in Conroy v. Aniskoff, 507 U.S. 511 (1993), the Supreme Court cited legislative history to support its conclusion that the Soldiers' and Sailors' Civil Relief Act of 1940 tolled the time period for a military officer to redeem property from foreclosure while the officer was in military service, regardless of whether the military service hindered the officer's ability to redeem the property. In overruling the state courts, the Supreme Court found that the statute on its face was "unambiguous, unequivocal, and unlimited" in tolling the redemption period. Id. at 518 (Scalia, J.
} 
in legislative history that are not incorporated into a statute are not to be treated as law. For example, in United States v. Gonzales, ${ }^{238}$ a federal statute provided that a defendant's federal sentence for using a firearm during the commission of a drug crime not run concurrently with any other sentence given in connection with the drug crime. A legislative committee report said that it was the intent that the federal firearm sentence be served first before any other sentence. ${ }^{239}$ Nothing in the actual statute addressed the order in which sentences were to be served. ${ }^{240}$ Lower courts used the legislative history to suggest that Congress meant to set the order in which defendants would serve multiple federal sentences (after all, the federal government had no control over the order of state sentences), and therefore it was appropriate to order that the defendant's federal sentence for using a firearm in connection with the drug crime be served concurrently with the defendant's state sentence for the drug crime. ${ }^{241}$ The Supreme Court reversed, holding that the statute was clear on its face in prohibiting concurrent sentences of any kind, and that it was inappropriate for the lower courts to consult legislative history to create an ambiguity that did not exist in the statute itself. ${ }^{242}$

The same analysis applies to the treatment of tax claims against non-electing debtors. The courts are improperly relying on a statement in a committee report as to how tax claims against debtors who do not make the split-year election are to be treated. The statute enacted by Congress does not speak to the treatment of tax claims against non-electing debtors. Moreover, the treatment suggested in the committee report is inconsistent with the general treatment of "claims" in bankruptcy. As in the Gonzales case, the statement in the committee report should not be relied on as law when Congress never enacted the statement into law. There is simply no proper basis for the suggestion that the statement in a committee report reflects Congressional intent when the issue was not addressed in the statute. Legislative history may properly be used to resolve statutory

concurring). The Supreme Court then proceeded to review snippets of legislative history suggesting that Congress intended to provide blanket protection for military officers while on active duty. Id. at 514-515. Justice Scalia wrote a lengthy concurring opinion criticizing the Court for discussing legislative history at all, since the statute on its face was clear and unconditional. Id. at 518 (Scalia, J. concurring). In Justice Scalia's view " $[\mathrm{t}]$ he language of the statute is entirely clear, and if that is not what Congress meant then Congress has made a mistake and Congress will have to correct it." Id. at 528. Justice Scalia noted that an examination of the legislative history might lead to the conclusion that Congress did not intend for the statute to be enforced as written, and suggested that any attempt to determine what Congress and the President intended would be disingenuous - the Court would only be citing the authority supporting its conclusion and ignoring contrary authority. See id. at 526-27, 519 (Scalia, J., concurring). The justices engaged in similar debates over the role of legislative history in other cases. See, e.g., Bank One Chicago., N.A. v. Midwest Bank \& Trust Co., 516 U.S. 264 (1996).

238520 U.S. 1 (1997).

${ }^{239} I d$. at 5 ("The excerpt from the Senate Report accompanying the 1984 amendment to $\S 924(\mathrm{c})$, relied upon by the Court of Appeals, reads: 'The Committee intends that the mandatory sentence under the revised subsection 924(c) be served prior to the start of the sentence for the underlying or any other offense.' S. Rep., at 313-314.").

${ }^{240} I d$. ("This snippet of legislative history injects into $\S 924(\mathrm{c})$ an entirely new idea - that a defendant must serve the five-year prison term for his firearms conviction before any other sentences.").

${ }^{241} I d$. at 7 ("Seeking to avoid this conflict between $\S 924$ (c) (as reinterpreted in light of its legislative history) and $\S 3584(\mathrm{a})$, the Court of Appeals held that $\S 924$ (c) only prohibited running federal terms of imprisonment concurrently.").

${ }^{242} I d$. at 7 ("The statutes clash only if we engraft onto $\S 924(\mathrm{c})$ a requirement found only in a single sentence buried in the legislative history: that the firearms sentence must run first. We therefore follow the text, rather than the legislative history, of $\S 924(\mathrm{c}) . ”)$. 
ambiguities, ${ }^{243}$ but it should not be used to create new law never enacted by Congress. The cases holding, on the basis of a statement in a committee report that was not reflected in the statute, that the government has no claim against the estate on account of prepetition taxes owing in the year of bankruptcy are not correctly reasoned. As a matter of policy, the estate benefits from any income earned during the pre-bankruptcy period, because that income becomes property of the estate (to the extent it still exists on the date of bankruptcy), ${ }^{244}$ and so the government, like every other creditor, should have a claim against the estate on account of that pre-petition income. As the corporate cases have held, the statute's provision of a single tax year does not prevent the bifurcation of the claim for priority purposes.

The only reason that the inconsistent treatment between corporate and individual cases has not caused havoc within the bankruptcy system is that the rulings have created a strong incentive ${ }^{245}$ for individual debtors to elect to split the year of bankruptcy, creating an eighth priority claim for the pre-petition portion of the of taxes for the year of bankruptcy under the post-petition assessability rule. ${ }^{246}$ Since most debtors presumably elect to split the year of bankruptcy, the system works for individual debtors the same way as for corporate debtors. However, as discussed below, ${ }^{247}$ it is unclear how these precedents will be applied to cases filed after the effective date of the 2005 Act.

\section{The Implication of the Post-petition Assessability Rule on Prepetition Taxes in the Year of Bankruptcy.}

The Bankruptcy Tax Act of $1980^{248}$ solved the problem of how to treat taxes incurred in the year of bankruptcy by individual taxpayers who make a split-year

\footnotetext{
${ }^{243}$ Toibb v. Radloff, 501 U.S. 157, 162 (1991) ("First, this Court has repeated with some frequency: 'Where ... resolution of a question of federal law turns on a statute and the intention of Congress, we look first to the statutory language and then to the legislative history if the statutory language is unclear." , quoting Blum v. Stenson, 465 U.S. 886 (1984)).

${ }^{244}$ See 11 U.S.C. $\S 541(\mathrm{a})(1)$ (estate entitled to all legal and equitable interests of the debtor in property as of the petition date).

${ }^{245}$ Debtors who make the split-year election obtain the benefit of having the estate liable to pay their prepetition tax liabilities. By making the estate liable, and providing the government with an eighth priority claim, there is a significant chance that the estate will use funds which would otherwise go to pay the debtor's other prepetition creditors to pay the debtor's non-dischargeable tax liabilities. Debtors thus have a strong incentive to make the split-year election in order to have the estate use money that would otherwise to other creditors to satisfy the debtor's own non-dischargeable obligation.

${ }^{246}$ See 11 U.S.C. § 507(a)(8)(A)(iii). Note that taxes on the debtor's post-petition earnings will be an administrative claim against the estate if the estate benefits from the income (see I.R.C. § 1398(e)(1)), as it will under the 2005 amendments to the Bankruptcy Act in most reorganization cases (see infra note 414). The government would not have a claim against the estate for taxes on the debtor's income in the usual Chapter 7 case, because the debtor's post-petition income is not property of the estate. See, e.g., 11 U.S.C. $\S 541(a)(6)$ (earnings on estate property attributable to debtor's post-petition services are not property of the estate); Tabb, supra note 19 at 299 ("anything the debtor earns before bankruptcy is fair game for payment to the debtor's pre-bankruptcy creditors, and comes into the estate, but the debtor's earnings after bankruptcy belong to the debtor alone, free from the clutches of the debtor's creditors"). Thus, the debtor would be solely liable for tax on the debtor's post-petition income in most Chapter 7 cases because the income is not property of the estate.

${ }^{247}$ See discussion infra beginning at page 41 .

${ }^{248}$ See supra note 192.
} 
election. $^{249}$ However, it caused great confusion over the proper treatment of claims for year-of-bankruptcy for all other taxpayers. ${ }^{250}$ The courts added to the confusion by treating non-electing individuals differently from corporations, even though there is nothing in the statute to justify the disparate treatment. ${ }^{251}$ The courts were wrong to rely on an unenacted statement in a committee report to hold that the government has no claim for year of bankruptcy taxes against the bankruptcy estate of a non-electing individual. $^{252}$ The statement in the committee report is not law, because it was never reflected in a statutory enactment. ${ }^{253}$ The Bankruptcy Code makes it clear that claims for taxes on prepetition income are prepetition "claims," even though the claims are deemed to arise under applicable non-bankruptcy law post-petition, at the end of the tax year (or possibly even when the return is due). ${ }^{254}$

Therefore, the government should have a claim against the bankruptcy estates of both corporate and non-electing individual debtors for the pro-rata portion of the year-ofbankruptcy taxes properly allocated on the basis of time to the prepetition period. ${ }^{255}$ The prepetition claim should be treated as an "allowed claim" under section 502(i), ${ }^{256}$ and should be given eighth priority under the post-petition assessability rule. ${ }^{257}$ The claim should not be entitled to first priority as an administrative expense for two reasons: (1) the claim is entitled to eighth priority and therefore is excluded from the definition of an administrative expense, ${ }^{258}$ and (2) the claim was not "incurred by the estate" since the estate did not exist when the income was earned and the tax claim accrued for bankruptcy purposes. ${ }^{259}$ Because the claim is entitled to eighth priority, the claim should be excepted from discharge in an individual Chapter 7 case. ${ }^{260}$

The prepetition portion of year-of-bankruptcy tax claims against taxpayers who make the split-year election should work the same way, but the amount of the claim should be calculated differently. Instead of allocating the year's taxes to the prepetition period on the basis of time, the claims against electing individual taxpayers will be computed on the basis of a separate return. ${ }^{261}$ For example, if a debtor filed bankruptcy on July 1, exactly half of the year will have occurred prepetition and half post-petition. If a non-electing debtor owed $\$ 100,000$ of taxes for the year, the government would have a $\$ 50,000$ eighth priority claim for the prepetition portion of the year. However, if the

\footnotetext{
${ }^{249}$ See discussion supra at notes 142 - 143.

${ }^{250}$ See discussion regarding treatment of corporate taxpayers beginning on page 23 and individual taxpayers who do not make the split-year election beginning on page 29 .

${ }^{251} I d$.

${ }^{252}$ See discussion supra beginning at note 238 .

${ }^{253} \mathrm{Id}$.

${ }^{254}$ See discussion supra beginning at note 218.

${ }^{255}$ See discussion supra beginning after note 186.

${ }^{256}$ See discussion supra beginning at note 230.

${ }^{257}$ See 11 U.S.C. $\S 507(a)(8)(A)$ (iii) (eighth priority for taxes assessable post-petition); I.R.C. $§ 6501($ a) (three year statute of limitations on assessment begins to run upon filing of return).

25811 U.S.C. $\S 503(\mathrm{~b})(1)(\mathrm{B})$.

${ }^{259} \mathrm{Id}$.

${ }^{260} 11$ U.S.C. $\$ 523(\mathrm{a})(1)(\mathrm{A})$. The claim is not discharged in a corporate Chapter 7 case because a corporation does not receive a discharge. 11 U.S.C. $\$ 727(a)(1)$ (only individuals receive Chapter 7 discharge). Whether the claims are dischargeable under the reorganization chapters is discussed below beginning on page 49 .

${ }^{261}$ I.R.C. $\S 1398(d)(2)(A)$.
} 
taxpayer made the split-year election, the taxpayer's liability would be computed on the basis of a separate return. If the taxpayer owed $\$ 70,000$ in taxes for the first half of the year and $\$ 30,000$ of taxes for the second half of the year, the government's eighth priority prepetition claim would be $\$ 70,000$ rather than $\$ 50,000$. With the split-year election, the debtor's claims will accurately reflect the actual income earned by the debtor pre-petition, rather than reflecting an average portion of the debtor's annual income allocated to the prepetition time period. There is, thus, a distinction between the treatment of electing and non-electing taxpayers, but it is not nearly as significant as treating the entire year-of-bankruptcy tax liability as a post-petition obligation of the debtor and not an obligation of the estate.

4. The Post-Petition Assessability Rule after the 2005 Act.

The most fundamental change made by the 2005 Act concerning income tax claims was a seemingly innocuous shift of language from section 507(a)(8)(A)(i) to the flush language of section 507(a)(8)(A). The language in question previously made it clear that the lookback rule only applied to tax years that ended prepetition. Thus, taxes in the year of bankruptcy could only fall within the lookback rule if the debtor made a split-year election or if the debtor filed bankruptcy on the last day of the debtor's tax year. ${ }^{262}$ In all other cases, the tax year will not have ended on or before the date of bankruptcy.

The movement of the language in the 2005 Act will have no effect on the lookback rule, because the language was previously set forth in the lookback rule. However, the movement of the language sets forth new rules that apply to the two other provisions of section 507(a)(8) - the 240 day rule, and the post-petition assessability rule. While a new requirement has been added to the 240-day rule, it will not change the rule, because the 240 -day rule only applied to taxes assessed prepetition. ${ }^{263}$ Since the tax year must end in order for taxes to be assessed, the change made by the 2005 Act will not effect the 240-day rule 264

However, the change made by the 2005 Act will have a substantial impact on the post-petition assessability rule. Like the lookback rule, after the 2005 Act the postpetition assessability rule will only apply to year-of-bankruptcy taxes if the debtor makes a split-year election or files bankruptcy on the last day of the tax year. In all other cases, the tax year will not have ended "on or before the petition date," and the post-petition assessability rule will not apply. In all other circumstances, year-of-bankruptcy taxes will not be entitled to eighth priority. The statutory change thus overrules the theory upon which the corporate cases, discussed beginning on page 23 , are based. ${ }^{265}$

It is not clear why Congress changed the statute. One possibility is that the court wanted to clarify that the post-petition assessability rule would not apply to taxes for years commencing post-petition. However, the courts have consistently held that the

\footnotetext{
${ }^{262}$ See discussion supra beginning at note 58.

${ }^{263}$ See 11 U.S.C. $§ 507($ a)(8)(A)(ii) (applies to "taxes assessed within 240 days . . before the date of the filing of the petition).

${ }^{264}$ See discussion supra beginning at note 75.

265 See supra notes 161, 166, 177.
} 
post-petition assessability rule would not apply to purely post-petition tax years. ${ }^{266}$ Did Congress simply intended to codify this rule? If so, Congress erred also by eliminating priority for the prepetition portion of year-of-bankruptcy taxes. The codification of the post-petition-year rule could have been made by simply saying that taxes for years beginning post-petition would not be covered by the post-petition assessability rule. Requiring the tax year to end pre-petition goes further by eliminating year-of-bankruptcy taxes from the application of the rule. ${ }^{267}$

A second possibility is that the change was made at the behest of the government, which has consistently argued that year-of-bankruptcy taxes should be treated as postpetition obligations - indeed, should be treated as first priority post-petition administrative expenses. ${ }^{268}$ However, the statute does not specify that all claims for taxes owing for the year of bankruptcy will be entitled to first priority as administrative expenses, but merely that the taxes will not be subject to eighth priority. Will the elimination of eighth priority accomplish the government's objective of turning the prepetition portion of year-of-bankruptcy taxes into first priority administrative expenses?

The corporate cases applied the post-petition assessability rule to grant eighth priority, rather than first administrative expense priority, to the prepetition portion of year-of-bankruptcy taxes. However, they were not consistent in rationalizing their rulings. The Court of Appeals for the Ninth Circuit in PATCO accepted the government's argument that an entire year's tax claim arose at the end of the tax year, but held nevertheless that the claim for the prepetition portion of the year's taxes constituted a eighth priority claim under the post-petition assessability rule. ${ }^{269}$ The PATCO panel did not attempt to distinguish the long line of authority holding that the post-petition assessability rule applies only to prepetition taxes. ${ }^{270}$ One would expect the government to argue that Congress intended the 2005 Act, by preventing the use of the post-petition assessability rule for year-of-bankruptcy taxes, to overturn PATCO and treat all of the taxes in the year of bankruptcy as if they had been "incurred by the estate," and thus as first priority administrative expenses. Using the PATCO panel's theory, the government may well succeed in arguing for administrative expense priority since the post-petition assessability rule no longer applies to prevent administrative priority. ${ }^{271}$

However, the PATCO panels' conclusion that the prepetition portion of year-ofbankruptcy taxes was incurred by the estate has not been universally accepted. Both the Court of Appeals for the Eighth Circuit in $O^{\prime} N e i l l$ Shoe ${ }^{272}$ and the Court of Appeals for the Eleventh Circuit in Hillsborough Holdings ${ }^{273}$ explicitly refused to decide whether the prepetition portion of year-of-bankruptcy taxes were incurred by the estate, holding simply that the taxes were covered by the post-petition assessability rule and thereby

\footnotetext{
${ }^{266}$ See supra note 136.

${ }^{267}$ Unless, of course, the debtor makes a split-year election under I.R.C. section 1398, or files bankruptcy on the last day of the tax year.

${ }^{268}$ See supra note 178.

${ }^{269} 64$ F.3d 1292, 1301-02 (9th Cir. 1995) discussed supra beginning at note 154.

270 See supra note 136.

${ }^{271}$ See 11 U.S.C. $\S 503(\mathrm{~b})(1)(\mathrm{B})(\mathrm{i})$.

${ }^{272} 64$ F.3d 1146 (8th Cir. 1995).

273116 F.3d 1391 (11th Cir. 1997).
} 
excluded from first priority administrative expense treatment. ${ }^{274}$ The cases involving individual debtors, in rejecting administrative priority for the prepetition portion of yearof-bankruptcy taxes, have held that the prepetition taxes were not "incurred by the estate." 275

While the government may have thought that eliminating eighth priority would make the entire year's tax claim an administrative expense, a proper reading of the statutory rules and longstanding bankruptcy policy suggests a different result. There is a great weight of bankruptcy authority suggesting that the government's "claim" 276 - here, the right to the payment of taxes on income earned prepetition - accrues when the income is earned, even though the amount is unliquidated and the claim is unmatured. ${ }^{277}$ Using the proper analysis of a bankruptcy "claim," the government's right to payment arose when the debtor earned the income. Since the bankruptcy estate was not in existence when the debtor earned the prepetition portion of the year-of-bankruptcy taxes, that liability could not have been "incurred by the estate." Thus, the government should have a prepetition claim for taxes owing on prepetition income. Using the proper definition of a bankruptcy claim, Congress, by eliminating the possibility of using the post-petition assessability rule, has turned the government's eighth priority claim, ${ }^{278}$ which was automatically excepted from discharge, ${ }^{279}$ into a dischargeable general unsecured claim.

\section{Administrative Priority Claims.}

As a general matter, two different taxpayers are created when a petition is filed ${ }^{280}$ by an individual debtor in a Chapter 7 case: the debtor and the bankruptcy estate. The debtor's post-petition earnings do not constitute property of the bankruptcy estate, ${ }^{281}$ and those earnings are not available to pay prepetition creditors. The debtor is responsible for filing a tax return and paying any taxes on the debtor's post-petition income if that income does not belong to the estate. ${ }^{282}$

\footnotetext{
${ }^{274}$ Hillsborough Holdings, 116 F.3d at 1394 ("We need not decide which of these positions is correct; we can assume for purposes of this appeal that the entire year's taxes were incurred by the estate.") supra note 165 .

${ }^{275}$ See supra note 191; Johnson, 190 B.R. at 726 (prepetition portion of year-of-bankruptcy taxes not "incurred by the estate").

${ }^{276}$ See 11 U.S.C. $\S 101(\mathrm{a})(5)(\mathrm{A})$ (a "right to payment, whether . . liquidated, unliquidated, fixed, contingent, matured, unmatured, disputed, undisputed, legal, equitable, secured or unsecured); see also discussion supra beginning at note 218.

${ }^{277}$ See discussion supra starting at note 211.

27811 U.S.C. $\S 507(\mathrm{a})(8)(\mathrm{A})(\mathrm{iii})$ (repealed 2005).

279 11 U.S.C. $§ 523(\mathrm{a})(1)(\mathrm{A})$ (excepting from discharge claims entitled to eighth priority under section $507(\mathrm{a})(8))$.

${ }^{280}$ See 11 U.S.C. $\S 541$ (a) (“commencement of case . . creates an estate").

${ }^{281}$ See, e.g., 11 U.S.C. $\$$ 541(a)(6) (earnings on estate property attributable to debtor's post-petition services are not property of the estate); Tabb, supra note 19, at $\S 5.8$, p. 299 ("anything the debtor earns before bankruptcy is fair game for payment to the debtor's pre-bankruptcy creditors, and comes into the estate, but the debtor's earnings after bankruptcy belong to the debtor alone, free from the clutches of the debtor's creditors").

${ }^{282}$ The debtor is not required to pay tax on the debtor's post-petition income if the estate is entitled to the income. See I.R.C. $\S 1398(\mathrm{e})(2)$. Thus, the distinction is made between post-petition income belonging to the estate (which is taxable to the estate), and post-petition income belonging to the debtor personally (which is taxable to the debtor personally).
} 
The bankruptcy estate of an individual debtor is comprised of most of the debtor's property existing on the petition date. ${ }^{283}$ Certain rights of an individual debtor acquired after the petition are also included in the estate, to limit the individual debtor's ability to time the receipt of assets to avoid having those assets used to pay creditor claims. ${ }^{284}$ An individual debtor is allowed to remove certain exempt property from the estate. ${ }^{285}$ In a Chapter 7 case, the trustee is required to liquidate the remaining property of the estate into cash, ${ }^{286}$ and to distribute the proceeds to creditors in accordance with the rules of distribution. ${ }^{287}$

Non-individual debtors are treated differently, because they have no separate existence from the bankruptcy estate. A corporate debtor therefore is not entitled to remove exempt property from the estate, ${ }^{288}$ and does not receive a discharge under Chapter $7,{ }^{289}$ because it will cease to exist after all of its assets are liquidated, and the proceeds are paid to creditors. The entire corporate existence is reflected in the bankruptcy estate, and all of the corporation's property as of the petition date is included in the bankruptcy estate.

The cleavage between the separate existence of the individual debtor and the bankruptcy estate, and the lack of cleavage between the corporate debtor and the bankruptcy estate, is reflected to some extent in the tax law. For individual debtors, the taxable income of the estate is to be computed separately and paid by the trustee. ${ }^{290}$ The income of the estate consists of the income to which the estate is entitled if it was "received or accrued" after the bankruptcy case. ${ }^{291}$ The income of the debtor consists of the income to which the bankruptcy estate is not entitled. ${ }^{292}$ An individual debtor in a Chapter 7 or 11 case can make a split-year election to treat the year of bankruptcy as two years (a prepetition and a post-petition year). ${ }^{293}$ If the election is not made, the debtor's taxable year is determined without regard to the bankruptcy case. ${ }^{294}$ For non-individual debtors (corporations and partnerships), and for individual debtors under Chapter 12 or 13, no separate taxable entity results for entity taxpayers. ${ }^{295}$ The statute thus reflects the separate existence of the individual debtor in Chapter 7 and 11 cases.

For all taxpayers, income earned by the estate on property of the estate is taxable to the estate. ${ }^{296}$ All of the income earned post-petition by entity taxpayers and individual

\footnotetext{
${ }^{283}$ See 11 U.S.C. $\S \S 541$ (a)(1) (property of the estate). Certain property nominally held by the debtor is excluded from the estate because it really belongs to someone else. See 11 U.S.C. $\S 541(b)$.

${ }^{284}$ Property of the estate includes, for example, property recovered by the trustee post-bankruptcy by avoiding a pre-petition transfer (11 U.S.C. $\$ 541(\mathrm{a})(3)$ ), and property inherited by the debtor within 180 days of bankruptcy (11 U.S.C. $\S 541(\mathrm{a})(5))$.

${ }^{285}$ See 11 U.S.C. $\S 522(\mathrm{~b})(1)$.

${ }^{286}$ See 11 U.S.C. $\$ 704(a)(1)$.

${ }^{287}$ See 11 U.S.C. $\$ 726$.

28811 U.S.C. $\S 522$ (b)(1) (applying exemption statute to an "individual debtor").

${ }^{289} 11$ U.S.C. $\S 727(\mathrm{a})(1)$ (only an individual receives a discharge).

${ }^{290}$ I.R.C. $\S 1398$ (c)(1).

${ }^{291}$ I.R.C. $\S 1398(\mathrm{e})(1)$.

${ }^{292}$ I.R.C. $\S 1398(\mathrm{e})(2)$.

293 I.R.C. $\S 1398(d)(2)$.

${ }^{294}$ I.R.C. $\$ 1398(d)(1)$.

${ }^{295}$ I.R.C. $§ 1399$ ("Except in any case to which section 1398 applies, no separate taxable entity shall result from the commencement of a case under title 11 of the United States Code.”).

${ }^{296}$ See I.R.C. $§ 1398(\mathrm{e})(1)$.
} 
taxpayers in Chapter 12 and 13 cases become property of the estate and thus are taxed to the single entity - the debtor. In individual Chapter 7 and 11 cases, taxes on the debtor's post-petition income is taxed to the debtor if the debtor does not have to turn that income over to the estate for use to pay creditors. Any income earned by the estate, and any income which the debtor has to turn over to the estate, will be taxed to the estate and not to the debtor. ${ }^{297}$

Under a change made the 2005 Act, an individual debtor will be able to confirm a Chapter 11 plan over the objection of a creditor only if the debtor either pays the claim in full with interest, or the value of property distributed under the plan exceeds the debtor's projected gross income during the 5-year period after the first plan payment is made under the plan. ${ }^{298}$ If the property of the estate does not vest in the debtor under the plan, and the debtor proposes to use post-petition income to pay creditors during the term of the plan, that income should be taxable to the bankruptcy estate and not the debtor. It remains to be seen how this provision will be interpreted and apply.

Claims for taxes owing by the estate on post-petition income should be entitled to first priority as administrative expenses. The statute provides that any tax "incurred by the estate" which is not entitled to eighth priority is an administrative expense. ${ }^{299}$ Prior to the 2005 Act, the courts consistently excluded taxes on post-petition income from eighth priority treatment, giving them first priority administrative expense status, although no court has provided sound reasoning for the exclusion. ${ }^{300}$ As explained earlier in this paper, ${ }^{301}$ the government's claim for taxes on post-petition income should not constitute an "allowed claim" in bankruptcy, ${ }^{302}$ and should therefore be excluded from eighth priority under the post-petition assessability rule. ${ }^{303}$ In the 2005 Act, Congress clarified (in this respect) the eighth priority rules by making them applicable only to tax years ending before the petition date. ${ }^{304}$ Therefore, it is now crystal clear that taxes on the estate's post-petition income will be entitled to administrative priority. Note, however, that taxes on an individual debtor's Chapter 7 or 11 post-petition income will not constitute a claim against the estate at all if income belongs to the debtor and not to the estate. $^{305}$

It is less a question of whether administrative priority is to be granted to some prepetition taxes. The government has long contended that prepetition taxes in the year of bankruptcy should be treated as first priority administrative expenses. ${ }^{306}$ The government has argued that all taxes in the year of bankruptcy first arise at the end of the

\footnotetext{
${ }^{297}$ I.R.C. $§ 1398(\mathrm{e})(1)$ (estate taxed on income to which the estate is entitled); $§ 1398(\mathrm{e})(2)$ (debtor not taxed on income to which the estate is entitled).

298 11 U.S.C. $\$ 1129(\mathrm{a})(15)$.

29911 U.S.C. $\$ 503(\mathrm{~b})(1)(\mathrm{B})(1)$.

${ }^{300}$ See discussion supra beginning at note 132 .

${ }^{301}$ See discussion supra beginning at note 138.

${ }^{302}$ Section 101(a)(5)(A) defines a claim as a right to payment. Section 502 treats claims as "allowed claims" if there is a right to payment as of the petition date. See 11 U.S.C. $\S 502(b)$. Since the government has no right to payment for taxes on income that has not yet been earned, there is no allowed claim on the date of the petition for taxes on income earned post-petition.

${ }^{303} 11$ U.S.C. $\S 507(a)(8)$ (provides eighth priority only for "allowed unsecured claims of governmental units").

304 U.S.C. $\$ 507(\mathrm{a})(8)$.

305 I.R.C. $\S 1398(\mathrm{e})(2)$.

${ }^{306}$ See supra note 178.
} 
tax year, and therefore are "incurred by the estate."307 The courts have consistently rejected the government's interpretation, finding in corporate cases that the prepetition portion of year-of-bankruptcy taxes are covered by the post-petition assessability rule, ${ }^{308}$ and finding in the individual cases (where the debtor does not make a split-year election) on the basis of a statement in a committee report to the Bankruptcy Tax Act of 1980 that all taxes in the year of bankruptcy are an individual obligation of the debtor and not an obligation of the estate. ${ }^{309}$ The situation is even more confused after the $2005 \mathrm{Act}$, because the basis for the corporate cases - the application of the eighth priority postpetition assessability rule - no longer applies to year of bankruptcy taxes. ${ }^{310}$ While the cases are poorly reasoned, they reach the correct result. Taxes on prepetition income should not be given first priority as administrative expenses because the tax claim arises prepetition, ${ }^{311}$ and therefore the taxes were not "incurred by the estate."

Prior to the 2005 Act, the statute granting administrative priority failed to specify whether secured claims were covered by the statute. ${ }^{312}$ The 2005 Act makes it clear that secured claims for post-petition taxes are entitled to first priority as administrative expenses. $^{313}$

\section{DischargeABILITY OF YEAR-OF-BANKRUPTCY TAX ClAIMS.}

There are three separate questions that must be answered in the affirmative before one can determine that a claim has been discharged in bankruptcy. First, the debtor must receive a discharge. Under Chapter 7 , only individual debtors are eligible to receive a discharge. ${ }^{314}$ Corporate and partnership debtors are not eligible to receive a Chapter 7 discharge. Moreover, even eligible individual debtors can be denied a discharge entirely for committing certain wrongful acts either a short time before or after bankruptcy. ${ }^{315}$ In addition, discharges can be denied if the debtor previously received a discharge within a certain period of time. ${ }^{316}$

Second, the discharge must by its terms apply to the claim. A Chapter 7 discharge only applies to claims "that arose before the date of the order for relief" or claims that are treated under section 502 as if they had arisen before the order for relief. ${ }^{317}$ The Chapter 7 discharge by its terms does not apply to claims which come into existence post-petition, unless section 502 specifically treats the claim as arising prepetition. Of particular relevance for income tax claims in the year of bankruptcy is section 502(i) of the Bankruptcy Code, which should require the prepetition portion of year-of-bankruptcy taxes to be treated as a prepetition allowed claim, even if applicable

\footnotetext{
${ }^{307}$ Id.; see also PATCO, 64 F.3d at 1298; O’Neill Shoe Co. , 64 F.3d at 1150.

${ }^{308}$ See discussion supra beginning on page 23.

${ }^{309}$ See discussion supra beginning on page 29.

${ }^{310}$ See discussion supra beginning on page 41.

${ }^{311}$ See discussion supra beginning after note 217.

312 See 11 U.S.C. $\S 503(\mathrm{~b})(1)(\mathrm{B})(\mathrm{i})$ (repealed 2005).

313 11 U.S.C. $\$$ 503(b)(1)(B)(i) (2005).

${ }^{314} 11$ U.S.C. $\S 727(\mathrm{a})(1)$ (denying discharge to debtors who are not individuals).

315 See 11 U.S.C. $\$ 727(\mathrm{a})(2)-(7)$ (concealing or destroying estate property or financial records, making a false oath, failing to explain losses, refusing to obey orders of the court).

${ }^{316}$ See 11 U.S.C. $\$ 727(a)(8)-(9)$.

317 11 U.S.C. $\$ 502(b)$.
} 
non-bankruptcy law the claim would treat the claim as arising post-petition. ${ }^{318}$ If the claim arose prepetition (or is treated by the section 502 as having arisen prepetition), the claim is subject to the discharge order even if no proof of claim was filed by the creditor and even if the claim was not allowed as part of the bankruptcy distribution process. ${ }^{319}$ Thus, as a general matter, prepetition claims will be subject to the discharge order while most post-petition claims will not be subject to the discharge order.

Finally, even if the debtor receives a discharge and the claim is covered by the discharge order, the particular claim may still be excepted from discharge. Section 523 of the Bankruptcy Code lists nineteen types of claim that are excepted from discharge. ${ }^{320}$ There are three basic types of claims excepted from discharge. The first type is claims arising out of the debtor's bad conduct, such as claims against the debtor for fraud, embezzlement, willful and malicious injury, and drunk driving. ${ }^{321}$ Most of these claims are excepted from discharge only if the creditor timely seeks and obtains an order from the Bankruptcy Court excepting the claims from discharge. ${ }^{322}$ Second, claims that the debtor knew about and failed to list in the bankruptcy schedules are not discharged. ${ }^{323}$ These claims are automatically excepted from discharge. Finally, certain claims are automatically excepted from discharge because of the nature of the claim or the claimant. This includes certain claims for things like spousal support, student loans, criminal restitution, and, most importantly for this article, certain tax obligations. ${ }^{324}$

Claims for taxes are excepted from discharge if the debtor failed to file a required tax return, ${ }^{325}$ filed a required tax return late and within two years of bankruptcy, ${ }^{326}$ or committed tax fraud. ${ }^{327}$

In addition, two types of taxes are excepted from discharge due to the timing of the taxes, rather then the debtor's tax liability resulting from bad acts. First, taxes entitled to priority under sections 507 (a)(2) ${ }^{328}$ are automatically excepted from discharge. ${ }^{329}$ Section $507(\mathrm{a})(2)^{330}$ grants a priority to so-called involuntary gap period taxes - taxes arising after the filing of an involuntary bankruptcy petition and before the order for

\footnotetext{
318 See discussion supra beginning at note 230. Even without section 502(i), the definition of a "claim" should include the prepetition portion of year-of-bankruptcy taxes. See discussion supra beginning at note 218.

31911 U.S.C. $\S 502(b)$.

${ }^{320}$ See 11 U.S.C. $\$ 523(\mathrm{a})$.

${ }^{321}$ See $\S 523(\mathrm{a})(2),(4),(6)$.

$32211 \S 523(\mathrm{c})(1)$.

$32311 \S 523(\mathrm{a})(3)$.

${ }^{324}$ See, e.g., 11 U.S.C. $\$ 523(\mathrm{a})(1),(5),(7),(8),(13)$.

${ }^{325} \S 523(\mathrm{a})(1)(\mathrm{B})(\mathrm{i})$

${ }^{326} \S 523(\mathrm{a})(1)(\mathrm{B})(\mathrm{ii})$ (return filed late and within two years of bankruptcy. Note that as a result of an apparent drafting error, claims for taxes covered by a late return filed more than two but fewer than three years before bankruptcy will fall within the post-petition assessability rule and will be excepted from discharge under section 523(a)(1)(A); see discussion supra after note 85.

${ }^{327} \S 523(\mathrm{a})(1)(\mathrm{B})(\mathrm{iii})$ (debtor filed a fraudulent return or willfully attempted to evade or defeat taxes).

${ }^{328}$ Under the 2005 Act, what was section 507(a)(2) has been renumbered as section 507(a)(3). 11 U.S.C. $\S$ $507(\mathrm{a})(3)$. The renumbering has occurred because a new category of claims has been given first priority spousal support claims. $\S 507(a)(1)$.

32911 U.S.C. $\$ 523(\mathrm{a})(1)$.

${ }^{330}$ See supra note 328.
} 
relief. ${ }^{331}$ These gap period tax claims are treated as allowed prepetition claims, ${ }^{332}$ given second priority, ${ }^{333}$ and are also excepted from discharge. ${ }^{334}$

Second, all taxes entitled to eighth priority are excepted from discharge. ${ }^{335}$ Taxes are entitled to eighth priority if covered by the lookback rule, the 240 day rule, or the post-petition assessability rule, discussed earlier. ${ }^{336}$ Prior to the 2005 Act, the courts correctly held that the government's claims for taxes incurred in the year of bankruptcy were not discharged. However, the rulings were not correctly analyzed.

The issue of dischargeability with respect to corporate taxes in Chapter 7 does not arise, because corporations do not receive aChapter 7 discharge. ${ }^{337}$ The issue does arise, however, with respect to individuals. Prior to the 2005 Act, the courts correctly held that the government's tax claims against individuals who made the split-year election would not be discharged because those claims were entitled to eighth priority under both the post-petition assessability rule and the lookback rule, and thus were excepted from discharge under section 523(a)(1)(A). ${ }^{338}$ The 2005 Act should not change this result, because the prepetition short year will still fall within the language of both the lookback and post-petition assessability rules, because, by definition, the short tax year will have ended on the petition date. ${ }^{339}$

This leaves the claims against non-electing individuals. Prior to the 2005 Act, the courts should have applied the post-petition assessability rule to the government's claims for the prepetition portion of year-of-bankruptcy taxes. ${ }^{340}$ Instead, however, the courts wrongly treated the government's claim as a post-petition personal obligation of the debtor and not as an obligation of the estate. ${ }^{341}$ The courts reached the correct result that the taxes were excepted from discharge, but for the wrong reason.

For cases subject to the 2005 Act, the prepetition portion of year-of-bankruptcy taxes incurred by non-electing individuals should be dischargeable, unless the debtor files bankruptcy on the last day of the tax year. The 2005 Act has eliminated eighth priority for these taxes incurred in the year of bankruptcy, unless the tax year ends on the petition date (as it does only if the debtor makes the split year election or files on the last day of the tax year). ${ }^{342}$ Since the prepetition portion of taxes in the year of bankruptcy would only be excepted from discharge if entitled to eighth priority (or incurred during the gap period), the non-priority taxes for the prepetition portion of the year of bankruptcy should be dischargeable. Eliminating the possibility of eighth priority has turned eighth priority

\footnotetext{
${ }^{331}$ See 11 U.S.C. $\S \S 507(a)(2), 502(f)$.

${ }^{332} \mathrm{Id}$.

${ }^{333} \S 507(\mathrm{a})(2)($ repealed 2005), 507(a)(3).

$334 \S 523(\mathrm{a})(1)(\mathrm{A})$.

${ }^{335} \mathrm{Id}$.

${ }^{336}$ See discussion infra beginning at page 5 .

${ }^{337}$ See supra note 314.

${ }^{338}$ See, e.g., In re McCready, 255 B.R. 834, 835 (Bankr. M.D. Tenn. 1999). With a split-year election, the partial pre-bankruptcy year ends on the petition date, and the taxes would be subject to eighth priority under either the lookback rule of 11 U.S.C. $\$ 507(\mathrm{a})(8)(\mathrm{A})(\mathrm{i})$ or the post-petition assessability rule of 11

U.S.C. $\S 507(\mathrm{a})(8)(\mathrm{A})(\mathrm{iii})$. See discussion supra at notes 65,142 , and 143 .

339 See 11 U.S.C. $\$ 507($ a)(1)(A)(i), (iii).

${ }^{340}$ See discussion supra beginning after note 193.

${ }^{341}$ See discussion supra beginning at page 29.

${ }^{342}$ See discussion supra beginning on page 41 .
} 
non-dischargeable taxes into dischargeable general unsecured claims. Taxes for the postpetition portion of the year of bankruptcy should not be covered by the discharge. ${ }^{343}$

However, the courts may continue to follow the erroneous decisions holding that the prepetition portion of year-of-bankruptcy taxes incurred by non-electing individual debtors arises post-petition, and is only a personal obligation of the debtor and not of the estate. $^{344}$ If the courts continue to follow these cases, which rely on a statement in a committee report that is not reflected in the statute, ${ }^{345}$ the government's tax claim will remain outside of bankruptcy and will not be affected by the changes made in the 2005

Act.

A third possibility is that the courts will adopt for non-electing individuals the theory applied by the Ninth Circuit Court of Appeals in $P A T C O^{346}$ to corporate taxpayers - that the prepetition taxes incurred by a debtor in the year of bankruptcy are deemed to arise post-petition, and are thus incurred by the debtor. ${ }^{347}$ If the court adopts the PATCO panel's reasoning, the prepetition portion of taxes in the year of bankruptcy will be entitled to first priority as an administrative expense, because the 2005 Act eliminated the possibility of applying the post-petition assessability rule to the taxes. The 2005 Act has thus thrown into limbo whether taxes owing by non-electing individuals for the prepetition portion of the year of bankruptcy will be dischargeable.

\section{TREATMENT OF YEAR-OF-BANKRUPTCY TAX CLAIMS IN CHAPTER PROCEEDINGS.}

1. Treatment of Claims Against the Estate.

\section{A. Chapter 11 Cases Prior to the 2005 Act.}

Unlike Chapter 7 where claims are paid in peri passu from the proceeds generated by the liquidation of the estate's property, claims against the Chapter 11 bankruptcy estate are paid in accordance with the terms of the debtor's confirmed plan of reorganization. ${ }^{348}$ The debtor's plan must meet a number of requirements in order to be confirmable. For example, first priority administrative expenses must be paid in cash on the effective date of the plan, unless the holder of the claim accepts different treatment. ${ }^{349}$ Similarly, unless the government agreed otherwise, eighth priority tax claims ${ }^{350}$ must be paid in deferred cash payments over a period not exceeding six years from assessment of the tax. ${ }^{351}$

\footnotetext{
343 See supra note 317.

${ }^{344}$ See discussion supra beginning at note 191.

345 Supra note 192.

${ }^{346}$ See discussion supra beginning at note 154.

${ }^{347}$ See supra note 155.

${ }^{348}$ See 11 U.S.C. $§ 1141$ (a) (plan binds debtor and creditors).

349 11 U.S.C. $\$ 1109(\mathrm{a})(9)(\mathrm{A})$.

${ }^{350}$ The eighth priority tax claim will consist of the prepetition separate return prepared by an eligible individual taxpayer who makes the split-year election, or a pro-rata share of the year's taxes for the prepetition portion of the year.

351 11 U.S.C. $\$ 1129(a)(9)(C)$ (repealed 2005).
} 
The use of the term "assessment" created some confusion. Year-of-bankruptcy taxes could not have been "assessed" prepetition, ${ }^{352}$ and the automatic stay prevents the commencement of most collection actions post-petition. ${ }^{353}$ However, special statutory rules allowed the government to assess unpaid prepetition taxes at any time after a bankruptcy petition is filed, without complying with the normal deficiency procedures. ${ }^{354}$ Therefore, the sooner the government made the assessment, the shorter the period over which the debtor could pay the claim following confirmation of a plan.

The government's claims for the pre-petition portion of year-of-bankruptcy taxes for both electing individual debtors and corporate debtors were treated as eighth priority, ${ }^{355}$ while the post-petition portions were treated as first priority administrative expenses. ${ }^{356}$ However, the cases holding that the government has no claim against the bankruptcy estate of non-electing individual taxpayers for year-of-bankruptcy taxes ${ }^{357}$ posed quite a theoretical problem in Chapter 11 cases because of the broader discharge. At least theoretically, the government would have no claim against the estate, and the debtor would still be able to discharge the taxes since they arose prior to confirmation of the plan. ${ }^{358}$

The Massachusetts Bankruptcy Court in In re Johnson ${ }^{359}$ followed the Chapter 7 cases holding that the government had no claim against the estate of a non-electing individual debtor for the prepetition portion of year-of-bankruptcy taxes. ${ }^{360}$ However, to prevent the debtor from being able to discharge those taxes as part of the debtor's Chapter 11 plan, the court held that the debtor's plan could be confirmed only if the debtor provided in the plan for payment of the taxes. ${ }^{361}$ The court did a poor job of explaining why the plan had to provide for payment of the debtor's personal post-petition tax obligations if the estate had no liability for them. ${ }^{362}$

\footnotetext{
${ }^{352}$ See discussion supra beginning at note 75.

${ }^{353}$ See generally 11 U.S.C. $\$ 362(a)$.

${ }^{354}$ See I.R.C. $\S 6871$ (b) (“Any deficiency . . . determined by the secretary . . . on . . . the debtor's estate in a case under title 11 of the United States Code . . . may despite the restrictions imposed by section 6213(a) on assessments, be immediately assessed if such deficiency has not theretofore been assessed in accordance with law."). There is a corresponding exception to the automatic stay for this assessment. 11 U.S.C. $\S$ 362(b)(9)(D).

${ }^{355}$ See supra note 142 (electing individual taxpayers); see also discussion supra beginning at page 23 (corporate taxpayers).

${ }^{356}$ See discussion supra beginning at page 43.

${ }^{357}$ See discussion supra beginning at page 29.

${ }^{358}$ See 11 U.S.C. $\S 1141(\mathrm{~d})(1)(\mathrm{A})$.

359190 B.R. 724 (Bankr. Mass 1995).

${ }^{360} \mathrm{Id}$. at 127. See also discussion of the Johnson case supra beginning at note 211.

361 Johnson, 190 B.R. at 628 ("[T] he Debtors' Chapter 11 plan must provide for payment of these taxes, as their payment is integral to the feasibility and good faith requirements of 11 U.S.C. $\S 1129$.").

${ }^{362}$ The Johnson court recognized that "the cases that have dealt with section 1398 in the context of Chapter 11 cases are vague as to the required treatment of post-petition liability to the IRS in plans of reorganization."Id. The Johnson court noted that the bankruptcy court in In re Santiago Vela, 87 B.R., 229, 231-32 (Bankr. D.P.R. 1988), stated that nonpayment of the personal tax obligation was grounds for converting or dismissing the bankruptcy case. However, the Santiago Vela case involved withholding taxes for which the estate was liable. The nonpayment of the taxes thus constituted a continuing loss to the estate, which is one of the grounds for conversion or dismissal. Santiago Vela, 87 B.R. at 231 ("the United States has asserted that the debtors' failure to pay their post-petition federal tax obligations constitutes a continuing loss to the estate and evidences the absence of a reasonable likelihood of rehabilitation under Section 1112(b)(1). The Court agrees....”). Unlike Santiago Vela, the Court in Johnson held that the taxes
} 
The Johnson court reached the right result for the wrong reason. The government should have had an eighth priority nondischargeable claim for the prepetition portion of year-of-bankruptcy taxes. ${ }^{363}$ Because individual Chapter 11 cases are quite rare, ${ }^{364}$ there are only a couple of other published opinions discussing the problem with the Chapter 11 discharge created by the courts treating the prepetition portion of year-of-bankruptcy taxes incurred by non-electing individual debtors as a personal obligation of the debtors rather than as a claim against the bankruptcy estate. ${ }^{365}$ The problem was caused by the courts erroneously relying on an unenacted statement in a committee report to deny the government a claim against the bankruptcy estate. ${ }^{366}$ Prior to the 2005 Act, the courts would not have had to twist the statutory language ${ }^{367}$ to prevent the debtor from discharging the taxes in Chapter 11 if they had recognized that the government is entitled to a claim against the debtor's estate for the prepetition portion of year-of-bankruptcy taxes. Using the proper analysis, the government's claim (prior to the 2005 Act) would have been entitled to eighth priority, ${ }^{368}$ and as such would have been excepted from Chapter 7 discharge. ${ }^{369}$ Claims excepted from discharge under Chapter 7 are likewise excepted from an individual debtor's discharge in Chapter $11 .{ }^{370}$

\section{B. Chapter 11 Cases Under the 2005 Act.}

The 2005 Act has made a number of changes in the treatment of the government's eighth priority tax claims under Chapter 11 . The debtor must pay eighth priority tax claims in "regular installment payments,",371 over five years from the date of the order for

were not owed by the estate. How could the nonpayment of taxes that were not owed by the estate constitute a continuing loss to the estate?

${ }^{363}$ See discussion supra beginning at page 39.

${ }^{364}$ According to statistics provided by the Office of the United States Courts, there were only 10,132 Chapter 11 cases filed in the 2004 calendar year. See Table F-2, U.S. Bankruptcy Courts, Business and Nonbusiness Bankruptcy Cases Commenced, By Chapter of the Bankruptcy Code During the Twelve Month Period Ended Dec. 31, 200, available at http://www.uscourts.gov/bnkrpctystats/bankrupt_f2table_dec2004.pdf. Of these, only 946 cases were nonbusiness filings. Id. While the court does not indicate what portion of the business filings were made by individuals, the total number of Chapter 11 cases is small in relation to the 1,597,462 bankruptcy cases filed in 2004 (less than one percent).

${ }^{365}$ In In re Smith, 210 B.R. 689, 692 (Bankr. D. Md. 1997), the Court followed Johnson in holding that a trustee could recover year-of-bankruptcy tax payments made by the debtor while the debtor was a debtorin-possession, because the estate was not liable for those payments and therefore the payments were improper. In In re Wood, 240 B.R. 609, 610 (C.D. Cal. 1999), the debtor sought to structure payment of the government's tax claim for the year of bankruptcy. The Wood court held that the plan could not restrain the government's efforts to collect the taxes from the debtor. Id. At 617. Interestingly, the Wood court suggested that the government's claim would be nondischargeable under Chapter 11 because it was excepted from discharge under section 523 of the Bankruptcy Code. Id. (the debtor's taxes "were in any event nondischargeable under $\S \S 1141(\mathrm{~d})(2)$ and 523 and thus could have been collected outside the plan"). Contrary to the Wood court's suggestion, nothing in section 523 excepts from discharge personal obligations of the debtor which are not claims against the estate.

${ }^{366}$ See discussion supra at note 192.

${ }^{367}$ See discussion supra beginning at note 359 .

${ }^{368}$ See discussion supra beginning at note 219.

36911 U.S.C. $\S 523(\mathrm{a})(1)(\mathrm{A})$.

${ }^{370} 11$ U.S.C. $\$ 1141(\mathrm{~d})(1)(\mathrm{A})$.

${ }^{371} 11$ U.S.C. $§ 1129(\mathrm{a})(9)(\mathrm{C})$. 
relief rather than six years from assessment, ${ }^{372}$ and must in all cases pay postconfirmation interest. ${ }^{373}$ A new statutory provision enacted by the 2005 Act requires the debtor to pay the rate of interest specified by applicable non-bankruptcy law. ${ }^{374}$ In addition, the 2005 Act requires that the treatment of the claim be "not less favorable than the most favored nonpriority unsecured claim provided for by the plan." "375 Thus, for cases filed after the effective date of the 2005 Act, the government's claim is well protected in Chapter 11. The only potential loss to the government is interest during the so-called "gap period" accruing between the filing of the petition and confirmation of the plan.

However, the prepetition portion of year-of-bankruptcy taxes will no longer be entitled to eighth priority under the $2005 \mathrm{Act}^{376}$ Instead, the taxes will either be treated as first priority administrative expenses, ${ }^{377}$ as general unsecured claims, ${ }^{378}$ or as postpetition claims against the debtor and not as claims against the estate at all. ${ }^{379}$ In the first situation, the government will be protected since administrative expenses must be paid in cash on the effective date. ${ }^{380}$ If the obligation is not treated as a claim against the estate, as suggested by the non-electing individual cases, then the issue of dischargeability will once again loom large. Dischargeability is discussed below. ${ }^{381}$ If the prepetition portion of year-of-bankruptcy taxes is treated as a general unsecured claim, as it should be treated under the statutory rules after the 2005 Act changes, ${ }^{382}$ then the government will be in the same position as any other general unsecured creditor.

General unsecured creditors are principally ${ }^{383}$ protected in Chapter 11 by the bestinterests-of-creditors test, which requires the debtor to show that objecting creditors will receive at least as much in value under the plan as they would receive in a liquidation. ${ }^{384}$ In addition, unless the class in which the government's claim is placed votes to accept the plan, ${ }^{385}$ the debtor either must pay the claim in full or retain no interest in the estate's property after confirmation. ${ }^{386}$

37211 U.S.C. $\S 1129(\mathrm{a})(9)(\mathrm{C})(\mathrm{ii})$.

${ }^{373}$ See $\S 1129(\mathrm{a})(9)(\mathrm{C})(\mathrm{i})$ (requiring that the total value of the claim "as of the effective date of the plan" be paid). The phrase "as of the effective date" requires maintaining the present discounted value of the claim by paying interest on the claim. See Till v. SCS Credit Corp., 541 U.S. 465, 467 (2004) (holding that interest must be paid to maintain "value as of the effective date").

374 11 U.S.C. $\$ 511$.

37511 U.S.C. $§ 1129(\mathrm{a})(9)(\mathrm{C})(\mathrm{iii})$.

${ }^{376}$ See discussion supra beginning at page 41 .

${ }^{377} I d$.

${ }^{378}$ Id.; see also supra note 275.

${ }^{379} \mathrm{Id}$.; see also discussion beginning at page 29.

${ }^{380} 11$ U.S.C. $§ 1129(a)(9)(A)$.

${ }^{381}$ See discussion infra beginning at page 58 .

${ }^{382}$ See discussion supra beginning at page 39.

${ }^{383}$ There are other protections for creditors in Chapter 11, such as requirements of good faith, legality and disclosure. See, e.g., 11 U.S.C. § 1129(a)(1)-(5).

${ }^{384} 11$ U.S.C. $\$ 1129$ (a)(7)(A)(ii).

${ }^{385}$ Voting is by class under Chapter 11, and a class accepts the plan if more than half in number of creditors holding at least two-thirds in amount of claims votes to accept the plan. 11 U.S.C. $\S 1126(\mathrm{c})$.

${ }^{386}$ See 11 U.S.C. $\$ 1129$ (b)(2)(B)(ii). Under the 2005 Act, an individual debtor may keep property acquired by the debtor post-petition, which is included in the estate under new section 1115, without running afoul of the cramdown rule. Id. 
The 2005 Act contains substantial new restrictions on an individual debtor's ability to confirm a Chapter 11 plan $^{387}$ These restrictions were enacted to prevent debtors who have the ability to pay their debts out of future income from discharging them in bankruptcy. The problem with Congress's theory is that the debtor's projected disposable income is based on the debtor's past earnings, rather than future earning capacity, and on standardized expenses, both of which may not be reflective of the debtor's actual ability to pay. Under the new provision, if any general unsecured creditor objects to the plan, the individual debtor must show that the value of property being distributed under the plan exceeds the debtor's projected disposable income during the 5 year period following the first plan payment. ${ }^{388}$ If the value of the debtor's projected disposable income during the five year period would exceed the value of the distributions to be made under the plan, and the plan does not provide for full payment of the claim with interest, the plan cannot be confirmed. Note that unlike Chapter 13 (but like Chapter 12), the rule does not require the debtor to actually use post-petition income to fund the plan. Rather, the rule merely provides that the distribution under the plan exceed what would be distributed out of the debtor's projected disposable income. If the value of the property of the estate exceeds the debtor's projected disposable income over the five-year period, it would appear that a plan could be confirmed using only estate property and estate earnings, without using any of the debtor's future income, to pay creditors.

Whether the new rule will have any impact on tax claims depends on whether the courts treat the government's claim for the prepetition portion of year-of-bankruptcy taxes by non-electing individual debtors as a dischargeable general unsecured claim, as they should, or, as they did in the past, whether they treat the government's claim as a personal nondischargeable obligation of the debtor that had to be provided for under the plan even though the government had no claim against the bankruptcy estate. In the former case, the debtor's projected disposable income test would have to be met to confirm a plan to pay the government less than full payment of its claim. In the latter case, the government would be entitled to full payment regardless of the test to be applied.

While confirming a Chapter 11 plan will not be easy, the government will bear a substantial risk that some portion of its claim for the prepetition portion of year-ofbankruptcy taxes will go unpaid if it has only a general unsecured claim against the estate for those taxes. By eliminating the possibility of eighth priority under the post-petition assessability rule, the 2005 Act exposes the government's claim against an individual debtor for the prepetition portion of year-of-bankruptcy taxes to discharge if the debtor's tax liability is properly treated as a "claim."

\section{The Estate's Liability for Post-Confirmation Interest and Penalties on Year-of-Bankruptcy Tax Claims.}

\footnotetext{
${ }^{387}$ Under the 2005 Act, an individual debtor will either have to pay all unsecured creditors, including the government's claim for prepetition taxes, in full with interest over the term of the plan, or use all of the debtor's projected disposable income for at least the five year period beginning on the date that the first payment is due under the plan to make payments to creditors. 11 U.S.C. $\S 1129(\mathrm{a})(15)$.

${ }^{388} 11$ U.S.C. $\S 1129$ (a)(15).
} 
Prior to the 2005 Act, the statute governing eighth priority claims did not contain the magic language that would require the payment of post-confirmation interest on the tax claim. ${ }^{389}$ This did not necessarily mean, however, that the debtor could confirm a plan to pay eighth priority tax claims over six years without interest. To confirm a plan of reorganization, the debtor also must show that the plan meets the so-called "bestinterests-of-creditors" test. The "best interests" test requires the plan proponent to show that the property to be distributed to an objecting creditor under the plan has at least as much "value as of the effective date of the plan" as the creditor would have received in a Chapter 7 liquidation occurring on the effective date of the plan. ${ }^{390}$ If the priority claim would have been paid in full from a Chapter 7 liquidation occurring on the effective date of the plan, then the debtor should be required to pay post-confirmation interest on the claim at a fair market rate in order for the proposed plan payments to have a "value as of the effective date of the plan" - or in financial terms a present discounted value - equal to the cash payment that would have been made in the hypothetical Chapter 7 case. If the priority claim would not have been paid in full in the hypothetical Chapter 7 liquidation, then the debtor must only pay the amount of interest necessary for the present value of the payment stream to equal or exceed the distribution that would be made in a Chapter 7 case. Therefore, the debtor may or may not be required to pay interest depending on the value of the Chapter 11 payment stream in comparison with the distribution that would be made in the hypothetical Chapter 7 case.

Prior to the 2005 Act, if the debtor was required to pay market-rate post-confirmation interest in order to meet the best interests of creditors test, the rate of interest would presumably be determined under the Supreme Court's "prime plus" formula, under which the prime rate is used as the base rate, and the creditor can seek to prove its entitlement to a premium to compensate for the additional risk of the loan to the debtor. ${ }^{391}$ Ultimately, the Bankruptcy Court would determine the appropriate interest rate on a case-by-case basis, without regard to the applicable non-bankruptcy rate. ${ }^{392}$ Where the debtor is not required to pay market rate interest (because the priority claim would not be paid in full in the hypothetical Chapter 7 case), the debtor could propose the lowest rate that would, using mathematical discounting formulas, result in the payment stream having a greater present value than the hypothetical Chapter 7 distribution.

\section{Chapter 12 and 13 Cases.}

Like creditors in Chapter 11, creditors in Chapter 12 and 13 cases are paid in accordance with the terms of the debtor's confirmed plan of reorganization, rather than from the proceeds generated by selling off the estate's property. Creditors holding priority claims receive special protection in Chapter 12 and 13 cases. In order to be confirmed, a Chapter 12 or 13 plan must provide for full payment of priority tax claims

\footnotetext{
${ }^{389}$ The statute did not require the payment stream to have a "value as of the effective date of the plan equal to the allowed amount of the claim." See § 1129(a)(9)(C) (repealed 2005); Till v. SCS Credit Corporation, 541 U.S. at 467.

${ }^{390} 11$ U.S.C. $\$ 1129(7)(A)(i i)$.

${ }^{391}$ See Till v. SCS Credit Corporation, 541 U.S. at 467.

${ }^{392} I d$.
} 
over the life of the plan. ${ }^{393}$ This rule applies to both first priority administrative expenses and eighth priority taxes. The plan term is generally three to five years. ${ }^{394}$ A debtor who fails to demonstrate the ability to pay all priority tax claims in full over the plan term will be unable to confirm a Chapter 12 or 13 plan, ${ }^{395}$ and the bankruptcy case will likely be converted to Chapter 7 or dismissed. ${ }^{396}$

The first question that must be considered is whether the government's claims for taxes incurred in the year of bankruptcy will be entitled to priority. As with corporate debtors, individual Chapter 12 and 13 debtors are not eligible to make a split-year election. Will the courts follow the corporate cases in treating the prepetition portion of year-of-bankruptcy taxes as an eighth priority claim, ${ }^{397}$ or will they will follow the nonelecting individual debtor cases in treating the claim as a personal obligation of the debtor and not an obligation of the estate? ${ }^{398}$ Only a few published opinions have addressed the issue.

The Bankruptcy Court in In re Michaelson ${ }^{399}$ felt bound by the Court of Appeals' corporate precedent in O'Neill Shoe Company, ${ }^{400}$ holding that the prepetition portion of year-of-bankruptcy taxes would be entitled to eighth priority under the post-petition assessability rule. In the opinion, however, the Michaelson court suggested that it disagreed with the Court of Appeals's decision in O'Neill Shoe, and went on to throw up its hands as to how the year's tax claim should be divided between the prepetition and post-petition period. The Michaelson court denied the debtor's motion to treat estimated tax payments as the amount of the eighth priority claim, but did explain how the prepetition portion of the claim should be determined, leaving the debtor in limbo. ${ }^{401}$

In an unpublished opinion, the bankruptcy court in In re Wilkoff, ${ }^{402}$ agreed with the Michaelson court that estimated taxes were irrelevant, but disagreed with the Michaelson court's holding that the government's claim for the pre-petition portion of year-of-bankruptcy taxes would be entitled to eighth priority. Instead, the Wilkoff court held that the government's claim for taxes in the year of bankruptcy arises post-petition, noting that other courts were in disagreement about whether the claim arises at the end of the tax year or when the tax return is due. Since in either case the claim in Wilkoff would

${ }^{393}$ See 11 U.S.C. $\S \S 1222(a)(2)$ (“[P]lan shall .. . provide for full payment, in deferred cash payments, of all claims entitled to priority under section 507, unless ... (B) the holder of a particular claim agrees to different treatment of such claim"), 1322(a)(2) (same).

${ }_{394} 11$ U.S.C. $\S \S 1222$ (c), 1322(d) (plans under Chapter 12 and 13 cannot exceed 3 years without court approval, or 5 years with court approval).

${ }^{395}$ The debtor must show that a plan is feasible in order to confirm the plan. See 11 U.S.C. $\S \S 1129(a)(11)$, 1225(a)(6), 1325(a)(6).

${ }^{396}$ See 11 U.S.C. $\S \S 1112$ (b)(1)(2) (repealed 2005), 1112(b)(4)(m), 1208(c)(3) - (5), 1307(c)(3), (5).

${ }^{397}$ See discussion supra beginning on page 23.

${ }^{398}$ See discussion supra beginning on page 29.

${ }^{399} 200$ B.R. 862, 866 (Bankr. Minn. 1996).

${ }^{400} 64$ F.3d 1146, 1151 (8th Cir. 1995), discussed supra beginning at note 164.

${ }^{401}$ Michaelson,, 200 B.R. at 868 ("[T] he Debtors must first identify their 1995 prepetition income. Then, it seems, the Debtors must show how pre and post-petition deductions, exemptions, credits, etc., affected that income to produce a calculated portion of their 1995 income tax liability. The question, more precisely, is: how can the Debtors relate their 1995 tax liability to their prepetition income without bifurcating the tax period? Perhaps, the answer is that they cannot."). The Michaelson court did not consider allocating the year's taxes pro-rata based on time. See discussion supra beginning at note 178 .

${ }^{402}$ No. 98-34354, 2001 Bankr. LEXIS 124, *18, 24-27, 87 A.F.T.R.2d (RIA) 2266, 2001-1 U.S. Tax Cas. $(\mathrm{CCH}) \uparrow 50,289$ (Bankr. E.D. Pa. 2001). 
have arisen post-petition, the court simply held that the claim arose post-petition. ${ }^{403}$ The Wilkoff court therefore applied section 1305(a), which allows but does not require the government to file a claim against the bankruptcy estate for taxes that "become payable" post-petition. ${ }^{404}$ The Wilkoff court held that since the government did not file a claim under section 1305(a), the debtor could not treat the claim under its plan. ${ }^{405}$ The Wilkoff court also held that the Chapter 13 discharge did not apply to the government's year-ofbankruptcy tax claim against the debtor personally, since by not electing to file a claim under section 1305(a), the government did not have an "allowed claim," and only "allowed claims" are covered by the Chapter 13 discharge. ${ }^{406}$ The Wilkoff court thus treated the question of whether the taxes "become payable" as determinative of when the "claim" arises for bankruptcy classification and priority purposes. Apparently under the Wilkoff court's analysis, the government would have the option either to file a proof of claim for taxes arising prepetition, which claim would be treated as an eighth priority non-dischargeable claim, or to not file a claim and have the taxes be deemed nondischargeable post-petition obligations that cannot be treated under the plan. ${ }^{407}$

While the Wilkoff court's holding may be consistent with the holdings made in the non-electing individual debtor cases, ${ }^{408}$ it is not consistent with the Bankruptcy Code's definition of a "claim." 409 A better reconciliation of the statutory language would be to apply section 1305(a) only to post-petition claims which become payable prior to confirmation. Prepetition claims which become payable post-petition should be treated as allowed prepetition claims under the general rules of section 502, and priority would be determined under the normal rules of section 507. Certainly, nothing in the language of section 1305(a) suggests that claims which would already be subject to section 502 somehow lose their status as "claims" simply because the government elects not to file a proof of claim.

If the Wilkoff case is followed after the 2005 Act becomes effective, there is little chance that the government will ever elect under section 1305(a) to file a claim for income taxes due in the year of bankruptcy. By eliminating eighth priority for the prepetition portion of year-of-bankruptcy taxes, the 2005 Act turns what should have previously been an eighth priority claim that had to be paid in full over time into a dischargeable general unsecured claim. If Wilkoff is followed, the debtor, by not making the split-year election, would cause the government's claim to be treated as if the bankruptcy case were never filed. The government would lose any claim against the

\footnotetext{
${ }^{403}$ Wilkoff, 2001 Bankr. LEXIS 124 at *10-12.

${ }^{404}$ Id. at *10; see also 11 U.S.C. $\$ 1305$.

${ }^{405}$ Wilcoff, 2001 Bankr. LEXIS 124 at $* 23-24$ ( "Since the IRS is an entity holding a claim for 'taxes that become payable to a governmental unit while the case is pending,' it had the option of filing a proof of claim for Debtors' 1998 income tax liability. It did not do so. Consequently, the claim was not allowed or disallowed under $\S 502$. Thus, the claim could not be provided for in the Plan."). Id.

${ }^{406} I d$. at *24 "Furthermore, only debts that 'have been provided for by' a Chapter 13 plan or 'disallowed under section 502' are discharged under $\S 1328(\mathrm{a})$. Consequently, when a holder chooses not to file a claim under $\S 1305$ (a), the claim is not discharged. Since the IRS chose not to file a claim under $\S 1305(a)$, its claim will not be discharged under $\S 1328(\mathrm{a})$ "). Id. (citations omitted).

407 Accord In re Olson, No. 02-83078, 2003 Bankr. LEXIS 1537, 4-7 (Bankr. D. Neb. 2003) (holding that government has election to file claim or to treat taxes incurred in the year of bankruptcy as nondischargeable post-petition claims).

${ }^{408}$ See discussion supra beginning at page 29.

${ }^{409}$ See discussion supra beginning at note 218 .
} 
debtor's bankruptcy estate on account of the year-of-bankruptcy tax liability, but the claim itself would be enforceable against the debtor immediately, and would not be affected by the debtor's bankruptcy discharge. Surely the government would prefer to be treated as a super-creditor, unimpaired by the bankruptcy and able to collect its claim in full immediately after confirmation, rather than as an ordinary general unsecured creditor holding a dischargeable claim.

If this is what Congress intended by section 1305, it should have done a better job of excepting the prepetition portion of year-of-bankruptcy taxes from the general definition of a "claim." The holding in Wilkoff would make it much more difficult for debtors with significant year-of-bankruptcy tax liabilities to perform under a confirmed plan, because it does not appear that the post-petition obligation to pay the taxes will be factored into the debtor's expenses in computing the debtor's "projected disposable income," all of which must be used to pay creditors under the plan. ${ }^{410}$ The loss of eighth priority is irrelevant under Wilkoff, because the court held that the government's tax claim would be protected from discharge even without eighth priority.

If the courts follow the holding of Michaelson, on the other hand, the loss of eighth priority ${ }^{411}$ will have a substantial impact on the government's rights. As a general unsecured creditor for the prepetition portion of year-of-bankruptcy taxes, the government will be entitled to share with other unsecured creditors in the funds available under the plan for distribution to general unsecured creditors. ${ }^{412}$ In all cases, the debtor must meet the best-interests-of-creditors test by showing that rejecting creditors receive as much in value as they would receive in a Chapter 7 liquidation on the effective date. ${ }^{413}$ In addition, the debtor must either pay the claim in full or use all of the debtor's "projected disposable income" for the three to five year term of the plan to pay creditors (or under Chapter 12 provide creditors with as much in value). ${ }^{414}$ Debtors who do not have enough "projected disposable income" to pay all general unsecured claims over the plan period should be able to confirm a Chapter 12 or 13 plan that pays only part of their year-of-bankruptcy taxes. The balance of the claim should be dischargeable.

The pre-2005 Act case law puts the government in a precarious position with respect to cases arising after the 2005 Act becomes effective. Under the theory used by the court in Wilkoff, the government should not file a claim because doing so will turn a non-dischargeable claim into a dischargeable one. Under the theory used by the court in Michaelson, the government's failure to file a proof of claim should enable the debtor to discharge the taxes. ${ }^{415}$

\footnotetext{
${ }^{410}$ See 11 U.S.C. $\S \S 1325(\mathrm{~b})(1)(B)$ (requiring that “all of the debtor's projected disposable income" during the plan period be "applied to make payments to unsecured creditors under the plan"), 1325(b)(2) (defining "disposable income" as "current monthly income ... less amounts reasonably necessary to be expended" for maintenance and support), 1325(b)(3) (providing that "reasonably necessary to be expended" refers to section 707(b)(2)(A) and (B)), and 707(b)(2)(A)-(B) (allowing a deduction for standard living expenses allowed under Internal Revenue Service guidelines for tax deficiencies. These guidelines make no allowance for the debtor's new bankruptcy obligation to pay taxes on pre-bankruptcy earnings).

${ }^{411}$ See discussion supra beginning after note 264.

${ }^{412}$ See 11 U.S.C. §§ 1123(a)(4) (same treatment of all claims in class), 1222(a)(3) (same), 1322(a)(3) (same).

${ }^{413} 11$ U.S.C. $\S \S 1129(\mathrm{a})(7)(\mathrm{A})(\mathrm{ii}), 1225(\mathrm{a})(4), 1235(\mathrm{a})(4)$.

${ }^{414} 11$ U.S.C. $\$ 1225(\mathrm{~b})(1)(\mathrm{B}),(\mathrm{C}), 1325(\mathrm{~b})(1)(\mathrm{B})$.

${ }^{415}$ See discussion infra at note 534 .
} 
A secondary question is whether the debtor must pay post-confirmation interest on priority taxes treated under the plan. This issue only applies to administrative priority post-confirmation taxes, and, prior to the 2005 Act, to prepetition taxes entitled to eighth priority. ${ }^{416}$ While the Chapter 12 and 13 statutes do not explicitly require the payment of post-confirmation interest on priority claims, ${ }^{417}$ a best-interests-of-creditors test similar to the one in Chapter $11^{418}$ does require the payment of post-petition interest if the creditor would have received full payment in a Chapter 7 liquidation occurring on the effective date of the plan. ${ }^{419}$ However, the debtor may be able to confirm a plan without paying priority creditors interest if the value of the plan's payment stream equals or exceeds the distribution that the government would receive in a Chapter 7 liquidation occurring on the effective date. Moreover, there is no requirement for paying post-petition preconfirmation interest (except on secured claims). ${ }^{420}$

\section{Dischargeability of Year-of-Bankruptcy Tax Clams in Chapter Proceedings.}

A. Chapter 11 Prior to the 2005 Act.

The Chapter 11 discharge provisions are more complex than the Chapter 7 discharge provisions, in large part because the courts have set entirely different rules for corporate debtors and non-electing individual debtors.

\section{i. Corporate Debtors.}

Corporate debtors generally ${ }^{421}$ receive a discharge in Chapter 11, even though they are excluded from receiving a discharge under Chapter $11 .^{422}$ Prior to the 2005 Act, corporate debtors could even discharge debts that would be excepted from an individual

\footnotetext{
${ }^{416}$ After the 2005 Act, the only way that year-of-bankruptcy taxes will be entitled to eighth priority is if the debtor files bankruptcy on the last day of the tax year. Chapter 12 and 13 debtors are not allowed to make the split-year election. I.R.C. $\S 1398(a)$. Therefore, all taxes in the year of bankruptcy were not incurred in a tax year ending on or before the petition date, unless the debtor files bankruptcy on the last day of the tax year. See 11 U.S.C. $\S 507(a)(8)(A)$. Eighth priority will therefore rarely apply to year-of-bankruptcy taxes in Chapter 12 and 13 cases.

${ }^{417} 11$ U.S.C. 9507 (a)(8)(A) (no requirement to pay "value as of effective date equal to the allowed amount of the claim").

${ }^{418}$ See discussion supra at note 390.

${ }^{419}$ See 11 U.S.C. $\S \S 1225(a)(4), 1325(a)(4)$. While the statutory language does not say that the court may confirm a plan only if it complies with the best-interests test, courts have refused to confirm plans that do not provide for the payment of interest on claims that would be paid in full in a Chapter 7 liquidation. See In re Sublett, 895 F.2d 1381, 1385-86 (11th Cir. 1990); In re Hardy, 755 F.2d 75, 76 (6th Cir. 1985) (refusing under best-interests test to confirm plan that provided for full payment of claims without interest); In re Martin, 17 B.R. 924, 925-26 (N.D. Ill. 1982) (same).

${ }^{420}$ See 11 U.S.C. $\$ 506(b)$.

${ }^{421}$ Corporate debtors do not receive a discharge if the plan provides for the liquidation of all or substantially all of the debtor's property, the debtor does not engage in post-confirmation business. See 11 U.S.C. $\S 1141(d)(3)$ (2005). If a corporate debtor has post-confirmation operations or does not liquidate, it is entitled to a Chapter 11 discharge upon confirmation of the plan. $\S 1141(\mathrm{~d})(1)$.

${ }^{422}$ See 11 U.S.C. $\S 541(\mathrm{~d})(1)-(2)$.
} 
debtor's discharge. ${ }^{423}$ Therefore, even though, as the courts have properly held, the prepetition portion of the government's year-of-bankruptcy corporate tax claim was entitled to priority under the post-petition assessability rule, ${ }^{424}$ it technically remained a dischargeable obligation under the Bankruptcy Code. The discharge, however, was of little moment if the government properly filed a claim and demanded the treatment to which it was entitled, because the government's eighth priority tax claim for the prepetition portion of the year's taxes had to be paid in full under the plan. ${ }^{425}$ However, because the obligation was discharged to the extent not provided for in the plan, questions regarding entitlement to and the rate of interest to be paid on the delinquencies were important. $^{426}$

\section{ii. Individual Debtors Who Make the Split Year Election.}

Dischargeability questions are also quite straight forward for individual debtors who make the split-year election. ${ }^{427}$ Taxes excepted from discharge under section 523 of the Bankruptcy Code are also excepted from an individual debtor's Chapter 11 discharge. ${ }^{428}$ If the debtor makes the election, the government's claim (both prior to and after the $2005 \mathrm{Act}$ ) for taxes owing for the prepetition partial-year will be entitled to eighth priority, ${ }^{429}$ and thus will be excepted from discharge under section $523 .{ }^{430}$ The government's claim will also, therefore, be excepted from the Chapter 11 discharge. $^{431}$

\section{iii. Individual Debtors Who Do Not Make the Split-} Year Election.

The issues are more complex for non-electing individuals. Even before the 2005 Act, claims that would be excepted from the Chapter 7 discharge were also excepted from an individual debtor's Chapter 11 discharge. ${ }^{432}$ Thus, under a correct reading of the Bankruptcy Code, ${ }^{433}$ the prepetition portion of the government's tax claims against individual debtors should be excepted from discharge. ${ }^{434}$

\footnotetext{
$423 \S 541(d)(2)$ (exception for debts excepted from discharge under section 523 only applies to individual debtors).

${ }^{424}$ See discussion supra beginning at page 23.

${ }^{425}$ See discussion supra at notes 351 (before 2005 Act), 371 (after 2005 Act).

${ }^{426}$ See discussion supra at notes 389 (no stated requirement for interest prior to 2005 Act), 373 (interest requirement under 2005 Act), 374 (rate of interest specified under 2005 Act).

${ }^{427}$ Individual debtors under both Chapter 7 and Chapter 11 are allowed to make the split-year election. See I.R.C. $\S 1398(a),(d)(2)(A)(2005)$.

${ }^{428} 11$ U.S.C. $\S 1141(\mathrm{~d})(2)(2005)$ ("The confirmation of a plan does not discharge an individual debtor from any debt excepted from discharge under section 523 of this title.").

${ }^{429}$ See discussion supra note 141 (before 2005 Act), beginning after note 264 (after 2005 Act).

${ }^{430} 11$ U.S.C. $\$ 523(\mathrm{a})(1)(\mathrm{A})$.

${ }^{431}$ See supra note 428.

43211 U.S.C. $\S 1141(\mathrm{~d})(2)(2005)$. The 2005 Act cleaned up the language by making it clear that it is the discharge, rather than the confirmation of the plan, that does not discharge an individual debtor from debts excepted from discharge under section 523. It is difficult to understand how the change in the language would change the effect of the provision.

433 As discussed supra beginning on page 29, the courts have incorrectly held that the prepetition portion of year-of-bankruptcy taxes for individual debtors did not fall within the post-petition assessability rule.
} 
Unfortunately, the courts have not granted eighth priority to the government's claim for the prepetition portion of year-of-bankruptcy taxes owed by non-electing individual debtors. ${ }^{435}$ Instead, most courts held that the entire tax claim for the year of bankruptcy (both the portion that related to prepetition income and the portion that related to post-petition income) was to be treated as a post-petition personal obligation of the debtor, and not an obligation of the estate, where an individual debtor failed to make a split-year election. ${ }^{436}$ The dischargeability problem was avoided in Chapter 7 because the courts held that the entire year's claim "arose" post-petition, ${ }^{437}$ and the Chapter 7 discharge only applied to prepetition claims. ${ }^{438}$ However, the Chapter 11 discharge is broader than the Chapter 7 discharge, applying to "any debt that arose before the date of .. . confirmation. $" ~ " 439$ Where the tax year ends post-petition, but prior to confirmation, it would thus appear, under the theory adopted by the courts in cases involving non-electing individuals, that the taxes for the year of bankruptcy would arise before confirmation and be dischargeable. Thus, the government could not collect the taxes from the debtor because they would be discharged by confirmation of the plan, and the government could not collect the taxes from the estate because the courts held that the estate is not liable for the taxes.

The only courts to consider the issue, however, did not rule that the taxes were uncollectible. In In re Wood, ${ }^{440}$ an individual Chapter 11 debtor sought to prevent the government from collecting prepetition year-of-bankruptcy taxes. The debtor had attempted to treat the claim under its plan of reorganization, even though the government had not filed a proof of claim. The district court began by stating that there was no

Rather, the courts have held that the taxes arise post-petition and do not constitute a claim against the estate. Under this theory, the claims are also not discharged because the claims arise after the petition date. Interestingly, this theory would expose the claims to discharge under Chapter 11, because the claims were not excepted from discharge under section 523 of the Bankruptcy Code. Since the Chapter 11 discharge applies to claims arising after the petition date but prior to confirmation, these erroneous rulings create the potential for discharging tax claims that should not be dischargeable. The district court in In re Wood, 240 B.R. 609, 613 (C.D. Cal. 1999), first held that the prepetition portion of taxes incurred in the year of bankruptcy did not constitute a claim against the estate. Then to avoid the problems with the Chapter 11 discharge, the Wood court held that the same claim was entitled to first priority as an administrative expense. $I d$. Since administrative expenses have to be paid in cash in full on the effective date of the plan (11 U.S.C. $\S 1129(a)((9)(A))$, there was no way for the debtor to discharge the tax liability. However, it makes no sense for the same tax claim not to be a claim against the estate for priority purposes, while at the same time being a claim against the estate for treatment as an administrative expense. The Wood court's conclusionary treatment of the problem was erroneous.

${ }^{434}$ Prior to the 2005 Act, the prepetition portion of year-of-bankruptcy tax claims should have been entitled to eighth priority under the post-petition assessability rule. See discussion supra beginning on page 39. In turn, claims entitled to eighth priority under 11 U.S.C. $\S 507(\mathrm{a})(8)(\mathrm{A})(\mathrm{iii})$ are excepted from discharge under 11 U.S.C. $\S 523(\mathrm{a})(1)(A)$. All claims against individual debtors that would be excepted from the Chapter 7 discharge have always been excepted from the Chapter 11 discharge as well. 11 U.S.C. $\S$

$1141(\mathrm{~d})(2)$.

${ }^{435}$ See discussion supra beginning at page 29.

${ }^{436}$ Id.; see also cases cited supra in note 191.

${ }^{437} \mathrm{Id}$.

${ }^{438}$ See 11 U.S.C. $\S 727($ b).

${ }^{439} 11$ U.S.C. $\$ 1141(\mathrm{~d})(1)(\mathrm{A})$.

440240 B.R. 609 (C.D. Cal. 1999). 
question but that the taxes were excepted from discharge under section $523 .^{441}$ The court did not explain how the taxes would be excepted from discharge under section 523, but in a footnote cited to section 523(a)(1)(A). ${ }^{42}$ The district court then held that the entire year's taxes arose post-petition because the debtor did not make a split-year election. ${ }^{443}$ According to the district court:

Wood's failure to make the election "leaves the IRS with a post-petition tax claim against [Wood] individually, [but] with no claim whatsoever against the bankruptcy estate for any part of the [1995] tax liability." 444

The Wood court did not explain how the taxes could be excepted from discharge under section 523(a)(1)(A), which only applies to prepetition eighth priority claims, after it had just ruled that the government had no claim whatsoever against the estate, and only a post-petition claim against the debtor. ${ }^{445}$

The district court's opinion in Wood is internally inconsistent and illogical. If the government's entire year-of-bankruptcy tax claim is deemed to arise post-petition, and is deemed to constitute only a personal obligation of the debtor and not an obligation of the estate, it cannot be excepted from discharge under section 523 of the Bankruptcy Code, because section 523 only applies to prepetition claims. Moreover, if the claim is not excepted from discharge under section 523, it would appear to be subject to the Chapter 11 discharge if the claim "arose" 446 prior to the confirmation date. The district court in Wood avoided the discharge question only through sloppy analysis and conclusionary and incorrect references to the Bankruptcy Code. While Congress likely did not intend to allow Chapter 11 debtors to avoid paying taxes incurred in year of bankruptcy, the theory adopted in the non-electing individual cases - that all year-of-bankruptcy taxes arise at the end of the tax year - is difficult to reconcile with the statutory language to achieve the result of excepting the taxes from discharge. ${ }^{447}$ The problem is that the underlying theory is wrong - prepetition taxes incurred in the year of bankruptcy should be treated as prepetition "claims." The theory adopted by the courts cannot be reconciled with the

${ }^{441} I d$. at 612 ("There is no question that Wood's federal income tax liabilities are nondischargeable under 11 U.S.C. $\S 523 . ”)$.

${ }^{442} I d$. at 613 n. 36 .

${ }_{443} \frac{d}{I d}$. at 613 ("Because Wood failed to bifurcate the tax year, his entire 1995 tax liability is a post-petition debt.").

${ }^{444} I d$. (citations omitted).

${ }^{445} 11$ U.S.C. $\S 523(\mathrm{a})(1)(\mathrm{A})$ excepts from discharge taxes "of a kind and for the periods specified in section $507(\mathrm{a})(2)$ and $507(\mathrm{a})(8)$ of this title."

${ }^{446}$ At the latest, the claim would arise when the return for the tax year was due, although most courts have suggested that the claim arises at the end of the tax year.

${ }^{447}$ One possibility is to argue that the post-petition, individual liability of the debtor for year-of-bankruptcy taxes does not constitute a "debt" within the meaning of the Bankruptcy Code, because the Chapter 11 discharge only applies to a "debt that arose before the date of such confirmation." A "debt" is defined in the Bankruptcy Code as "liability on a claim." 11 U.S.C. § 101(12). This brings us back to the Bankruptcy Code's broad definition of a "claim." § 101(5); see also discussion supra beginning at note 228. If the courts wish to follow the theory in the non-electing individual debtor cases (that the claims are personal post-petition obligations of the debtor and not claims against the estate), they should reconcile their rulings with the case law defining a bankruptcy claim. This will be difficult to do, since the Bankruptcy Code defines a "claim" so broadly. 
case law defining when a "claim" exists for bankruptcy purposes, ${ }^{448}$ and applying the statutory rules would appear to make the government's claim for taxes incurred prepetition in the year of filing dischargeable and uncollectible in a Chapter 11 case.

\section{Chapter 11 after the 2005 Act.}

The 2005 Act has made a number of changes to the Chapter 11 discharge provisions that create greater uncertainty about the dischargeability of year-of-bankruptcy taxes. The most important change is that Congress has eliminated the possibility of treating as eighth priority the government's claim for the prepetition portion of year-ofbankruptcy taxes. ${ }^{449}$ The impact of this change on corporate and individual debtors is discussed below. Congress has also changed the timing of the Chapter 11 discharge for individual debtors, and has enacted new provisions to except certain tax claims from broad corporate discharge.

\section{A. Corporate Taxpayers.}

Because corporate debtors could previously discharge in Chapter 11 debts that would be excepted from discharge if the debtor had been an individual, ${ }^{450}$ the exception from discharge for eighth priority claims under section 523(a)(1)(A) did not apply to corporate Chapter 11 debtors. ${ }^{451}$ In corporate Chapter 11 cases, the main protection for the government's claim for the prepetition portion of year-of-bankruptcy taxes was its eighth priority. The debtor could not confirm a plan without providing for the full payment of the eighth priority claim. ${ }^{452}$

Since the Chapter 11 discharge applies only to obligations that are not set forth in the plan, ${ }^{453}$ the debtor's obligation under the plan to pay the claim in full would not be discharged. Thus, if the government properly filed a proof of claim and demanded the treatment accorded by Chapter 11 to the claim, the government's rights would in general be protected.

By eliminating eighth priority treatment for the prepetition portion of the government's claim for taxes incurred in the year of bankruptcy, Congress has likewise eliminated the protection previously granted to the claims as a result of the priority. ${ }^{454}$

\footnotetext{
${ }^{448}$ See discussion supra beginning at note 228.

${ }^{449}$ See 11 U.S.C. $\$ 507(a)(8)(A)(2005)$, discussed supra beginning at page 41 .

${ }^{450}$ See 11 U.S.C. $\$ 1141(\mathrm{~d})(2)$ (excepting from the Chapter 11 discharge debts covered by section 523 only if the debtor is an individual).

${ }^{451} I d$.

452 See supra note 351.

45311 U.S.C. $\S 1141(\mathrm{~d})(1)$ ("Except as otherwise provided in . . . the plan . . the confirmation of the plan discharges the debtor from any debt.")

${ }^{454}$ It remains to be seen whether the courts will treat the government's claim for the prepetition portion of year-of-bankruptcy taxes as a general unsecured claim. The elimination of eighth priority removes the leg upon which the court's previous theory in corporate cases rested. See discussion supra beginning on page 23. It remains to be seen whether the courts will now treat the prepetition portion of year-of-bankruptcy corporate taxes as prepetition general unsecured claims or as first priority administrative expenses. See discussion supra beginning at page 41. For the remainder of the discussion, I assume that the courts will
} 
Without priority, the government's claim for the prepetition portion of year-ofbankrutpcy taxes should be treated as a general unsecured claim. ${ }^{455}$ General unsecured claims do not have to be paid in full under the plan; indeed with the right facts a debtor should be able to confirm a plan providing for no distribution to general unsecured creditors. $^{456}$ The portion of the claim which is not to be paid under the plan will be discharged. ${ }^{457}$ The principal effect of the 2005 Act on the dischargeability of year-ofbankruptcy tax claims does not, therefore, occur as a direct result of a change to the dischargeability rules. Rather, it is the change in the priority rules which causes taxes that were previously required to be paid in full under the plan to become dischargeable.

The 2005 Act also contains a new provision directly changing the dischargeability rules. New section 1141(d)(6)(B) excepts from the corporate discharge traditional tax fraud claims. ${ }^{458}$ The provision applies to fraudulent returns and willful attempts to "evade or defeat such tax."459 These provisions will likely apply to earlier years' taxes rather than to taxes in the year-of-bankruptcy, because such actions taking place postpetition would likely result in dismissal or conversion of the bankruptcy case. ${ }^{460}$

\section{B. Individual Taxpayers.}

The changes made by the 2005 Act should not have a significant impact on those who make a split-year election. If the split-year election is made, the taxes for the prepetition "year" of filing will be entitled to eighth priority under both the lookback rule and the pre-petition assessability rule, and will be excepted from discharge under section 523(a)(1)(A). The changes made by the 2005 Act clarify the requirement to pay postconfirmation interest on the claim, ${ }^{461}$ and require that the applicable non-bankruptcy rate of interest be utilized. ${ }^{462}$

The 2005 Act may have a more significant impact on individual debtors who do not make the split-year election. Under the 2005 Act, the government's claims against individual debtors who do not make the split-year election for the prepetition portion of year-of-bankruptcy taxes would no longer be entitled to eighth priority. ${ }^{463}$ If the courts had properly applied the post-petition assessability rule to these claims prior to the 2005 Act, the change would result in the government's claim for prepetition year-ofbankruptcy taxes losing all priority and becoming dischargeable. As a general unsecured creditor, the government would receive on account of its claim for the prepetition portion

apply existing bankruptcy law concerning when a "claim" exists for bankruptcy purposes, rather than creating a separate doctrine for tax cases.

${ }^{455}$ See discussion supra beginning at note 383 .

${ }^{456}$ See $\mathrm{i} d$. If the government would receive no distribution in a Chapter 7 liquidation because there is not enough liquidation value in the estate to pay higher priority creditors in full, and the debtor's shareholders retain no interest in the debtor, the plan could be confirmed over the government's objection without making any distribution on account of the government's general unsecured claim.

${ }^{457} 11$ U.S.C. $\S 1141(\mathrm{~d})(1)(\mathrm{A})$.

${ }^{458} \S 1141(\mathrm{~d})(6)(\mathrm{B})$.

$459 \mathrm{Id}$.

${ }^{460}$ See 11 U.S.C. § 1112(b)(2) (conversion or dismissal for "cause"), (4)(i) ("cause" includes failing to file tax returns due post-petition or to pay post-petition taxes).

${ }^{461} 11$ U.S.C. $\S 1129(\mathrm{a})(9)(\mathrm{C})$.

46211 U.S.C. $\$ 511$ (a) (requiring interest on tax claims to be paid at the applicable nonbankruptcy rate).

${ }^{463}$ See discussion supra beginning on page 41 . 
of year-of-bankruptcy taxes only the payments called for by the plan, which could be substantially less than full payment.

However, prior to the 2005 Act, the courts did not accord eighth priority to the government's claim for the pre-petition portion of year-of-bankruptcy taxes. Instead, the courts held in non-electing individual Chapter 7 cases that the government had no claim against the estate, ${ }^{464}$ and held in the few Chapter 11 cases that discussed the issue, using faulty reasoning, that the claims had to be paid under the plan and were excepted from discharge under section 523(a)(1)(A). ${ }^{465}$ The elimination of eighth priority may have no effect on these rulings, because the courts had not accorded the claims eighth priority in the past. If, as argued above, these cases are wrong, the impact of the 2005 Act's elimination of eighth priority will be substantial.

The 2005 Act contains two new Chapter 11 dischargeability exceptions. First, individual debtors do not receive a discharge up front on the effective date of the plan. ${ }^{466}$ Instead, the discharge is held in abeyance until all payments under the plan are completed. ${ }^{467}$ A new provision allows the bankruptcy court to grant a "hardship discharge" even if the debtor does not complete all payments required by the plan, if creditors received more in value under the plan than they would have received in a Chapter 7 liquidation occurring on the effective date of the plan, and modification of the plan would not be practical. ${ }^{468}$ If the government's claim for the prepetition portion of year-of-bankruptcy taxes were to be properly treated as a general unsecured claim against the estate, this new provision would provide some protection in the event the debtor fails to make the payments called for by the plan, but would still permit the discharge of amounts not provided for in the plan (or in the case of a hardship discharge, even amounts provided for in the plan and not paid if the hardship standards are met). However, if the courts treat the prepetition portion of year-of-bankruptcy taxes as a personal obligation of the debtor, as they did in non-electing individual cases prior to the $2005 \mathrm{Act}^{469}$ the new provisions would appear not to impact year-of-bankruptcy tax claims because they would already be excepted from the Chapter 11 discharge.

Second, the 2005 Act excepts certain corporate fraud claims from the previouslyunlimited Chapter 11 discharge. Corporate debtors cannot discharge tax claims with respect to which the corporation made a false return or willfully attempted to evade or defeat taxes. ${ }^{470}$ As long as the debtor did not commit tax fraud, the prepetition portion of year-of-bankruptcy taxes remains dischargeable in corporate Chapter 11 cases.

\section{Using a Chapter 11 Plan to Delay Payment of Non- Dischargeable Taxes.}

\footnotetext{
${ }^{464}$ See discussion supra beginning on page 29.

${ }^{465}$ See discussion supra beginning on page 59.

${ }^{466}$ See 11 U.S.C. $\S 1141(\mathrm{~d})(1)$ (repealed 2005) ("[C]onfirmation of the plan . . discharges the debtor")

${ }^{467} 11$ U.S.C. $\$ 1141(\mathrm{~d})(5)$. This provision applies unless the court, for cause, orders otherwise.

${ }^{468}$ See 11 U.S.C. $\S 1141(\mathrm{~d})(5)$. In addition, no hardship discharge can be granted in certain circumstances where the debtor committed fraud or may be found guilty of security fraud or certain other felonies. Id.; see also 11 U.S.C. $\S 522(\mathrm{q})$.

${ }^{469}$ See discussion supra beginning at page 59.

${ }^{470} 11$ U.S.C. $\S 1141(\mathrm{~d})(6)(B)$.
} 
Even if the government's tax claim is excepted from discharge, the debtor may still be able to use the bankruptcy case to delay payment or limit the amount of the government's claim. What happens, for example, if the government's claim is allowed in a certain amount under the plan, and the government later seeks to hold the debtor personally liable for additional amounts? In Snyder v. United States, ${ }^{471}$ a Michigan District Court held that the government was bound, under principles of res judicata, to the amount of the claim set forth in the plan, and thus could not recover the additional amounts from the debtor. Similarly, in In re Martin, ${ }^{472}$ a California Bankruptcy Court held that the government could not seek to enforce a non-dischargeable tax claim outside of the provisions of the plan where the government had participated in plan negotiations and had agreed to the plan terms. ${ }^{473}$ Other courts have held that the government can seek more than is specified in the plan if the government's claim is not dischargeable, even where the amount specified in the plan was based on proofs of claim filed by the government. ${ }^{474}$ The government was involved in actual negotiations with the debtor in those cases restricting the government's ability to collect non-dischargeable taxes.

The courts have also been unclear about the debtor's ability to use a plan to provide additional time for paying nondischrgeable taxes. One California bankruptcy court ruled that a debtor, under a provision in a confirmed plan of reorganization, could enjoin the government from collecting non-dischargeable taxes during the plan term. ${ }^{475}$ A California district court disagreed with the first court's reasoning, suggesting that the plan could not impair the rights of a creditor holding a non-dischargeable claim, or at a minimum the court would have to make specific findings that the collection activity would jeopardize the plan's success or frustrate the debtor's rehabilitation before the government's rights could be impaired. ${ }^{476}$ More recently, the Ninth Circuit Bankruptcy Appellate Panel focused on the need for the debtor "to prove that [the injunction] is necessary to allow the debtor to successfully reorganize and to perform the terms of the Chapter 11 plan." ${ }^{477}$ While one commentator has read the cases to suggest that a plan could modify the government's collection rights "regardless of whether the taxing agency actually consented," 478 the cases certainly suggest that requests by the debtor to modify the government ability to collect non-dischargeable taxes will not be easily granted.

\footnotetext{
${ }^{471} 213$ B.R. 321,323 (E.D. Mich. 1997)

${ }^{472} 150$ B.R. 43, 46 (Bankr. S.D. Cal. 1993).

${ }^{473}$ See also In re Matunas, 261 B.R. 129, 133 (Bankr. D.N.J. 2001) (the government could not seek to collect 1993 taxes which had not been preserved under the terms of a post-confirmation stipulation that was based on the terms of the debtor's plan of reorganization).

${ }^{474}$ See, e.g., DePaolo v. United States, 45 F.3d 373, 375-76 (10th Cir. 1995) (the government filed proofs of claim for non-dischargeable taxes in the wrong amount, and the court allowed the government to recover additional amounts from the debtor because the claim was not discharged.); In re Sage, No. 01-3288, 2002 U.S. Dist. LEXIS 2896, at *7, 89 A.F.T.R.2d (RIA) 783 (D.N.J. 2002) (same); In re McConahey, 192 B.R. 187, 190-91 (Bankr. S.D. Ill. 1996) (same with respect to non-dischargeable employment tax claim filed in wrong amount).

${ }^{475}$ In re Mercado, 124 B.R. 799, 800 (Bankr. C.D. Cal. 1991).

${ }^{476}$ In re Wood, 240 B.R. 609, 616-17 (C.D. Cal. 1999).

${ }^{477}$ In re Brotby, 303 B.R. 177, 190 (B.A.P. 9th Cir. 2003); see also In re Bartleson, 253 B.R. 75, 80-84

(B.A.P. 9th Cir. 2000) (because plan failed to specifically provide that government would be enjoined from collecting non-dischargeable taxes outside of plan, no res judicata issue could apply).

${ }^{478}$ C. Richard McQueen \& Jack F. Williams, TAX ASPECTS OF BANKRUPTCY LAW AND PRACTICE, § 10.11, p. 10-22 (2nd Ed., 1999)
} 
D. Claims for Interest and Penalties on Non-Dischargeable Taxes in Chapter 11.

Dischargeability is also important with respect to post-petition interest and penalties not provided for under the plan. The basic bankruptcy principle is that claims are determined as of the petition date, ${ }^{479}$ and unmatured interest is not allowed. ${ }^{480}$ The Bankruptcy Code allows only oversecured creditors to include in the amount of the claim post-petition interest. ${ }^{481}$ In a Chapter 7 case, all prepetition creditors are entitled to recover post-petition interest at the legal rate after all other claims are paid in full. ${ }^{482}$ In this way, all general unsecured creditors are treated equally, whether their contracts provided for interest or not. Therefore, it has long been the general rule that the government cannot include in its claim against the estate post-petition pre-confirmation interest. $^{483}$

In Chapter 11, there is no provision for the payment of post-petition preconfirmation interest to unsecured creditors, although the best interests of creditors test might require the payment of interest if prepetition interest would have been paid in a Chapter 7 liquidation occurring on the effective date of the plan. ${ }^{484}$ Whether the estate must pay post-confirmation interest under a plan is considered above. ${ }^{485}$ However, the Bankruptcy Code only addresses the government's ability to recover interest as part of its claim against the bankruptcy estate. The Bankruptcy Code does not address whether the debtor remains personally liable for interest if the government's claim is not dischargeable.

Prior to the enactment of the current Bankruptcy Code, the Supreme Court held in Bruning $v$. United States ${ }^{486}$ that post-petition interest on a nondischargeable tax debt could be collected from the debtor and was itself excepted from discharge, because the interest was part of the tax under applicable non-bankruptcy law. ${ }^{487}$ Bruning has been followed after the enactment of the Bankruptcy Code by courts in every circuit. ${ }^{488}$

\footnotetext{
${ }^{479}$ See 11 U.S.C. $\S 502$ (b)(2005) ("[T]he court . . shall determine the amount of such claim in lawful currency of the United States as of the date of the filing of the petition.").

48011 U.S.C. $\$ 502(\mathrm{a})(2)$.

${ }^{481}$ See 11 U.S.C. $§ 506(b)$ (interest is allowed to the extent the value of the collateral exceeds the amount of the secured creditor's claim); see also United States v. Ron Pair Enters. Inc., 489 U.S. 235, 235 (1989) (allowing secured tax claimant to recover interest under 11 U.S.C. $\S 506(b)$ ).

48211 U.S.C. $\$ 726(\mathrm{a})(5)$.

${ }^{483}$ See New York v. Saper, 336 U.S. 328, 332 (1949).

${ }^{484}$ See 11 U.S.C. $§ 1129$ (a)(7)(A)(ii); Kitrosser v. CIT Group/Factoring, Inc., 177 B.R. 458, 467-72 (S.D.N.Y. 1995)

${ }^{485}$ See discussion supra beginning at note 389.

${ }^{486} 192$ F. Supp. 826 (S.D. Cal. 1961), aff'd, 317 F.2d 229 (9th Cir. 1963), aff'd, 376 U.S. 358 (1964).

${ }^{487} I d$. at 829 ("The Bankruptcy Act expressly excepts taxes from discharge and the clear language of the revenue statute adds interest to the tax. The result is that interest added to the tax is excepted from discharge.")(Footnote omitted).

${ }^{488}$ See, e.g. In re Tuttle, 291 F.3d 1238, 1243 (10th Cir. 2002) (following Bruning, and stating "Although a few bankruptcy courts have held Bruning inapplicable to Bankruptcy Code cases, those decisions subsequently were reversed."); In re Cousins, 209 F.3d 38, 40-41 (1st Cir. 2000) (Bruning survived enactment of the Bankruptcy Code); Pardee v. Great Lakes Higher Educ. Corp., 218 B.R. 916, 921 (9th Cir. 1998); In re Johnson, 146 F.3d 252, 255 (5th Cir. 1998); Leeper v. Pa. Higher Educ. Assistance Agency, 49 F.3d 98, 101-02 (3d Cir. 1995) (recognizing in dicta that Bruning remains good law); In re Shumate,
} 
Therefore, although the government will generally not be entitled to recover post-petition interest and penalties as part of its claim against the bankruptcy estate, if the government's claim is excepted from discharge it may pursue the debtor after bankruptcy to recover post-petition interest and penalties.

\section{E. Chapters 12 and 13.}

Any debt excepted from discharge under section 523(a) of the Bankruptcy Code is also excepted from the Chapter 12 discharge. ${ }^{489}$ Because the prepetition portion of yearof-bankruptcy tax claims should properly have been entitled to eighth priority, ${ }^{490}$ and because all eighth priority claims are excepted from discharge under section 523(a)(1), ${ }^{491}$ a Chapter 12 debtor should not have been able to discharge the prepetition portion of year-of-bankruptcy tax claims. ${ }^{492}$ Because a Chapter 12 debtor is, like a corporate debtor, unable to make the split-year election, the corporate cases applying eighth priority to the pre-petition portion of year-of-bankruptcy taxes would likely apply under Chapter $12 .{ }^{493}$

Prior to the 2005 Act, Chapter 13 differed from Chapter 12 in providing a "superdischarge" under which some taxes excepted from discharge in Chapter 7 under section 523 could be discharged under a Chapter 13 plan. ${ }^{494}$ Notably, taxes excepted from discharge under section 523(a)(1) were not excepted from the Chapter 13 discharge. $^{495}$ At first blush, it would appear that priority tax claims could be discharged in Chapter 13 . However, a careful analysis shows that the prepetition portion of year-of-bankruptcy taxes could not really be discharged in Chapter 13, assuming that the government's tax claim was properly granted eighth priority under the post-petition assessability rule. This is because all priority tax claims must be paid in full under a Chapter 13 plan, ${ }^{496}$ and a debtor could receive the super-discharge only if the debtor completed all payments under

No. 90-2026, 1992 U.S. App. LEXIS 407 at*14 (4th Cir. 1992) (dicta); Klingman v. Levinson, 877 F.2d 1357, 1362-63 (7th Cir. 1989); In re Hanna, 872 F.2d 829, 830-31 (8th Cir. 1989); In re Burns, 887 F.2d 1541, 1543 (11th Cir. 1989); United States v. River Coal Co., 748 F.2d 1103, 1106-07 (6th Cir. 1984); In re Boccio, 281 B.R. 171, 175 (Bankr. E.D.N.Y. 2002).

${ }^{489}$ See 11 U.S.C. $\S 1228(a)(2)(2005)$.

${ }^{490}$ See discussion supra beginning at page 29.

${ }^{491} 11$ U.S.C. $\S 523(\mathrm{a})(1)(\mathrm{A})$.

${ }^{492}$ Note however that the courts have ruled, incorrectly in this author's opinion, that the government's claim for year-of-bankruptcy taxes incurred by taxpayers who do not make the split-year election is not entitled to priority under section 507(a)(8)(A)(iii). See discussion supra beginning at page 29. These courts have reasoned that the taxes arise post-petition, do not constitute claims against the bankruptcy estate, and are not covered by the Chapter 7 discharge. Presumably, under the theory adopted by these courts, since the government's tax claim would not be "provided for by the plan," nor allowed under section 503 or disallowed under section 502, the Chapter 12 discharge would not discharge these claims. See 11 U.S.C. $\S 1228(\mathrm{a})$.

${ }^{493}$ See discussion of In re Michaelson supra note 397.

${ }^{494}$ See 11 U.S.C. § 1328(a) (Repealed 2005).

${ }^{495} \mathrm{Id}$.

${ }^{496} 11$ U.S.C. § 1322(a)(2). 
the plan. ${ }^{497}$ Therefore, the discharge would apply only after the priority tax claim is paid in full - rending the discharge mostly ${ }^{498}$ irrelevant.

Chapter 13 also contained a separate hardship discharge provision applicable when all payments under the plan were not completed, but the hardship discharge did not discharge any debts excepted from discharge under section 523(a). ${ }^{499}$ Therefore, under a proper reading of the statutory rules, ${ }^{500}$ the debtor had no real ability to discharge prepetition taxes incurred in the year of bankruptcy, assuming that the government timely acted to protect its interests. ${ }^{501}$

The 2005 Act creates uncertainty concerning the proper treatment of the prepetition portion of year-of-bankruptcy taxes under Chapter 13. Because year-ofbankruptcy taxes will no longer be eligible for eighth priority treatment (unless the debtor files bankruptcy on the last day of his or her tax year), the prepetition portion of year-ofbankruptcy taxes should constitute general unsecured claims against the bankruptcy estate, ${ }^{502}$ and should be dischargeable in a Chapter 12 or Chapter 13 case - if the debtor can comply with the other requirements for confirming a plan. ${ }^{503}$ As a general unsecured creditor, the government has significantly less protection than it had as a priority creditor.

However, Chapters 12 and 13 contain some protections for general unsecured creditors. Similar to the requirement in Chapter $11,{ }^{504}$ in order to confirm a Chapter 12 or

${ }^{497} 11$ U.S.C. $§ 1328$ (a) (“As soon as practical after completion by the debtor of all payments under the plan ... the court shall grant the debtor a discharge.").

${ }^{498}$ As discussed supra after note 415 , it is possible that post-petition interest on the tax claim could be discharged because the requirement to pay priority claims in full does not specifically require full payment of the claim together with interest. However, the best interests of creditors test in 11 U.S.C. § 1325(a)(4), or the cramdown requirements in 11 U.S.C. $\S 1325(b)(1)$, could require the payment of interest in certain circumstances.

49911 U.S.C. $\S 1328(\mathrm{c})(2)$.

${ }^{500}$ It is unclear whether the court's holding that the government's prepetition claim against a debtor who fails to make the split-year election for taxes owing in the year of bankruptcy does not constitute a claim against the estate (see supra note 191) would apply under Chapter 13, because Chapter 13 debtors, like corporate debtors, are not eligible to make the split-year election. See I.R.C. § 1398(a). The bankruptcy court in In re Michaelson, 200 B.R. 862, 865-66 (Bankr. Minn. 1996), felt bound by the Court's of Appeal's precedent in In re L.J. O'Neill Shoe Company, 64 F.3d 1146, 1151 (8th Cir. 1995) (discussed supra beginning at note 164), which applied to corporate debtors, in holding that the government's claim for the prepetition portion of year-of-bankruptcy taxes owing by an individual Chapter 13 debtor was entitled to priority under section 507(a)(8)(A)(iii). The Michaelson court suggested, however, that it disagreed with O'Neill Shoe, and went on to throw up its hands as to how the year's tax claim should be divided between the prepetition and post-petition period. The Michaelson court correctly held that the debtor's attempt to use the amount of estimated tax due for the period was incorrect. Rather, the Court held that the year's actual taxes would have to be allocated somehow, but how? The Michaelson court did not decide: "the Debtors must first identify their 1995 prepetition income. Then, it seems, the Debtors must show how pre and post-petition deductions, exemptions, credits, etc., affected that income to produce a calculated portion of their 1995 income tax liability. The question, more precisely, is: how can the Debtors relate their 1995 tax liability to their prepetition income without bifurcating the tax period? Perhaps, the answer is that they cannot." Michaelson, 200 B.R. at 868. The court did not consider allocating the year's taxes pro-rata based on time. See discussion supra beginning at note 179 .

${ }^{501}$ See discussion infra note 534.

${ }^{502}$ Assuming, of course, that no tax fraud was committed in connection with the taxes which would create an independent ground for non-dischargeability. See 11 U.S.C. § 523(a)(1)(C).

${ }_{503}$ Both the Chapter 12 and Chapter 13 discharge apply broadly to "claims" addressed in the plan. See 11 U.S.C. $\S \S 1228,1328$.

${ }^{504}$ See supra note 387. 
Chapter 13 plan, a debtor must meet a best interests of creditors test by showing that objecting creditors will receive at least as much in present discounted value under the plan as the creditor would receive in a liquidation occurring on the effective date. ${ }^{505} \mathrm{In}$ addition, the debtor must show either (a) that the creditor will receive full payment of the claim with interest ${ }^{506}$ (at the applicable non-bankruptcy rate), ${ }^{507}$ or (b) that all of the debtor's projected disposable income during the three (or with the court's permission five $)^{508}$ year plan period will be used to make payments to unsecured creditors. ${ }^{509}$ In a Chapter 12 case, the debtor can meet the requirement by distributing property of a value equal to the debtor's projected disposable income for the three to five year period is distributed to creditors. ${ }^{510}$ Chapter 13 appears to require the debtor to use the projected disposable income to fund the plan. ${ }^{511}$ "Projected disposable income" is defined somewhat differently in Chapter 12 and Chapter 13, but the basic requirements are quite similar. ${ }^{512}$ Therefore, debtors who do not have enough projected disposable income to pay all general unsecured claims over the plan period should be able to pay only part of their year-of-bankruptcy taxes, and discharge the balance, in a Chapter 12 or Chapter 13 plan. ${ }^{513}$

One difficult problem that has arisen in Chapter 13 cases concerns the timing of the plan. A Chapter 12 plan must be filed within 90 days after the order for relief. ${ }^{514} \mathrm{~A}$ Chapter 13 plan must be filed within 15 days after the Chapter 13 petition is filed (or within 15 days after the case is converted to Chapter 13). ${ }^{515}$ If a debtor files bankruptcy early in the tax year, the amount of tax for the year, and hence the allocable portion for the prepetition and post-petition period, may not be established at the time the plan is filed because the year has not ended and the return is not yet due. Most of the litigation over timing has focused on a special rule contained in Chapter 13, which allows the government to file a claim for taxes which "become payable" while the case is pending. ${ }^{516}$ The claim for taxes which "become payable" post-petition while the case is

\footnotetext{
${ }^{505} 11$ U.S.C. $\S \S 1225(\mathrm{a})(4), 1325(\mathrm{a})(4)$. This best interests of creditors test requires the payment stream under the plan to be discounted to present value and compared with the distribution that would be made in a Chapter 7 liquidation occurring on the effective date.

${ }^{506}$ See 11 U.S.C. $\S \S 1225(\mathrm{~b})(1)(\mathrm{A}), 1325(\mathrm{~b})(1)(\mathrm{A})$.

50711 U.S.C. $\$ 511(\mathrm{~A})$.

50811 U.S.C. $\S 1222(\mathrm{c})$.

${ }^{509} 11$ U.S.C. $\S \S 1225(\mathrm{~b})(1)(\mathrm{B}), 1325(\mathrm{~b})(1)(\mathrm{B})$.

${ }^{510} 11$ U.S.C. $\$ 1225(\mathrm{~b})(1)(\mathrm{C})$.

511 11 U.S.C. $\$ 1325(\mathrm{~b})(1)(\mathrm{B})$.

512 Compare 11 U.S.C. $\S 1225(\mathrm{~b})(2)$ with 11 U.S.C. $\S 1325(\mathrm{~b})(2)$.

${ }^{513}$ However, if the courts follow the theory adopted by the Pennsylvania Bankruptcy Court in its unpublished opinion in In re Wilkoff, No. 98-34354, 2001 Bankr. LEXIS 124, 87 A.F.T.R.2d (RIA) 2266, 2001-1 U.S. Tax Cas. (CCH) 950289 (Bankr. E.D. Pa. 2001), and the government does not file a proof of claim, the debtor would remain personally liable for the taxes because they are treated as unimpaired by the bankruptcy proceeding. See discussion, supra, beginning at note 402 .

${ }^{514} 11$ U.S.C. $\S 1221$. Note that the period can be extended by the court for cause due to circumstances beyond the debtor's control. Id.

${ }^{515}$ See bankr. rule 3015(b). Note that the period can be extended for cause.

51611 U.S.C. $\S 1305(\mathrm{a})(1)$.
} 
pending is treated as if it had arisen prepetition for purposes of allowance. ${ }^{517}$ The meaning of the words "becomes payable" has vexed the courts. 518

Moreover, because the language of the section applies at the option of the taxing authority, debtors attempting to file claims on behalf of the taxing authority in order to provide for payment over the plan term rather than upon demand or levy have not been successful. $^{519}$ The section only allows the government the option of filing a claim for post-petition taxes which become payable during the pendency of the case to obtain treatment under the plan. It does not require prepetition claims which become payable post-petition to be treated as post-petition claims, as some courts have held. ${ }^{520}$ The debtor should be permitted to file a proof of claim on behalf of the government for the prepetition portion of year-of-bankruptcy taxes if the government fails to do so under general bankruptcy principles. ${ }^{521}$ The special rule allowing the government to file a claim for a tax that become payable post-petition does not in any way impair the normal rules applicable to prepetition claims.

All of this begs the question of how the prepetition portion of year-of-bankruptcy taxes can be treated under the plan when the amount will not be known until after the end of the year, when the return is filed. This same issue occurs with respect to any claim that is contingent or unliquidated at the time the plan is proposed. The general rule in bankruptcy is that contingent and unliquidated claims must be estimated by the court when the fixing of the claim would unduly delay the administration of the case. ${ }^{522}$ The debtor should seek to have the amount of the claim determined for purposes of allowance and treatment in bankruptcy, and the bankruptcy court should then estimate the claim by apportioning the debtor's projected tax liability. Admittedly, this is not an ideal solution. It would be far better to have the debtor file a split-year return so that the actual partialyear tax liability can be easily determined and properly treated. Congress, however, has chosen to preclude Chapter 13 debtors from making the split year election, so there is no other method for making the allocation.

What happens if the court's estimate of the claim turns out to be wrong? Presumably, if the court's estimate is too high, the debtor would be eligible for a refund

${ }^{517} 11$ U.S.C. $§ 1305$ (b) (claim "shall be allowed or disallowed under section $502 \ldots$ but shall be determined as of the date such claim arises, and shall be allowed under section 502(a) . . the same as if such claim had arisen before the date of the filing of the petition").

${ }^{518}$ See, e.g., In re Wilkoff, 2001 Bankr. LEXIS 124, *13-14 (becomes payable either at the end of the year or when the return is due); In re Dixon, 218 B.R. 150, 152 (B.A.P. 10th Cir. BAP 1998) (taxes become payable when tax year ends); In re Hudson, 158 B.R. 670, 673-74 (Bankr. N.D. Ohio 1993) (same); In re Matravers, 149 B.R. 204, 206 (Bankr. D. Utah 1993) (same); In re Ripley, 926 F.2d 440, 443-44 (5th Cir. 1991) (taxes become payable when return due).

${ }^{519}$ See In re Wilkoff, 2001 Bankr. LEXIS 124 (rejecting debtor's attempt to file claim for Internal Revenue Service on the basis of estimated taxes); In re Bryant, No. 94-13471, 1998 Bankr. LEXIS 1889, *11 (Bankr. E.D. Va. Apr. 24, 1998) ("Whether to file a claim under § 1305(a) is a voluntary decision on behalf of the governmental unit, and it is well established that the debtor, trustee, or any other party in interest other than the governmental unit cannot file a proof of claim on behalf of the taxing authority"); In re Michaelson, 200 B.R. at 865, n.3 (same); In re Ripley, 926 F.2d at 443 n.12 (5th Cir. 1991).

${ }^{520}$ See, e.g., In re Hudson, 158 B.R. 670, 673-74 (Bankr. N.D. Ohio 1993).

${ }^{521}$ See 11 U.S.C. $§ 501$ (c) (if a creditor does not timely file a proof of such creditor's claim, the debtor or the trustee may file a proof of such claim).

${ }^{522} 11$ U.S.C. $\S 502(\mathrm{c})(1)$. 
under applicable non-bankruptcy law. ${ }^{523}$ If the court underestimates the tax liability, the government can recover the additional amounts only if the government's claim is not discharged by the plan. Because (prior to the 2005 Act) the prepetition portion of yearof-bankruptcy taxes should have been entitled to eighth priority under the post-petition assessability rule, ${ }^{524}$ and because all eighth priority claims are excepted from discharge ${ }^{525}$ the claim would not have been discharged by confirmation of the Chapter 12 plan, ${ }^{526}$ and the government should have been able to recover from the debtor any additional amounts owing. In a Chapter 13 case, however, the government would be bound by the court's estimation of the claim, because even tax claims excepted from discharge under Chapter 7 under section 523(a)(1) could be discharged in Chapter 13. ${ }^{527}$

The 2005 Act has compounded the problem by eliminating eighth priority for year-of-bankruptcy taxes, thus transforming what should have been an eighth priority non-dischargeable claim into a non-priority dischargeable general unsecured claim. ${ }^{528}$ After the 2005 Act, the court's estimate of the prepetition portion of year-of-bankruptcy taxes should now be binding on the government, and any balance not paid under the plan should be discharged upon the completion of plan payments ${ }^{529}$ - unless the claim is otherwise excepted from the Chapter 13 discharge, which it will rarely be. ${ }^{530}$

Dischargeability is important in situations other than the court's underestimation of the prepetition portion of year-of-bankruptcy taxes. Unless a claim is excepted from the Chapter 12 or Chapter 13 discharge, the plan's proposed treatment of a claim is binding on the creditor. ${ }^{531}$ Thus, without an exception to discharge, if the plan proposes to pay less than the full amount of the claim, the creditor will be bound by the plan's proposed treatment unless the creditor successfully objects to confirmation. ${ }^{532}$ Similarly, if the plan mentions a claim but does not provide for payment, the debtor does not have to pay the claim. ${ }^{533}$ Most importantly, if a Chapter 13 plan proposes to pay allowed claims, but the government fails to timely file a proof of claim, the claim need not be paid and is

\footnotetext{
${ }^{523}$ See I.R.C. $\$ 6511$ (a) (statute of limitations on claims for refund is later of three years after date taxes were due or two years after date the taxes were paid.).

${ }^{524}$ See discussion supra beginning at page 39.

${ }^{525} 11$ U.S.C. $\$ 523(\mathrm{a})(1)(\mathrm{A})$.

${ }^{526}$ See 11 U.S.C. $\S 1228(\mathrm{a})(2)$.

${ }^{527}$ See 11 U.S.C. $\S 1328(\mathrm{a})$.

${ }^{528}$ See discussion supra beginning at page 41.

529 See 11 U.S.C. $\$ 1328(a)$.

${ }^{530}$ The 2005 Act has substantially restricted the super-discharge in Chapter 13, by excepting from the Chapter 13 discharge many claims excepted from discharge under section 523(a). These include tax claims for which a return was not filed or was filed late and within two years of bankruptcy, and tax fraud claims. See 11 U.S.C. $\S \S 523(a)(1)(B),(C) ; 1328(a)(2)$. Interestingly, claims excepted from discharge under section 523(a)(1)(A) because they are entitled to eighth priority remain dischargeable under Chapter 13. See 11 U.S.C. $\S 13218(a)(2)$.

${ }^{531}$ See 11 U.S.C. $\S \S 1228(a) ; 1328(a)$ (discharge applies to all claims "provided for by the plan or disallowed under section 502 ").

${ }^{532}$ See In re Tomlan, 102 B.R. 790, $793-94$ (E.D. Wash. 1989), aff'd, 907 F.2d 114 (9th Cir. 1990) (allowing discharge of priority tax claim in Chapter 13 case because plan referred to debt, and government failed to file a timely claim).

${ }^{533}$ See, e.g., In re Hairopoulos, 118 F.3d 1240, 1243 (8th Cir. 1997); In re Gregory, 705 F.2d 1118, 1122 (9th Cir. 1983) ("[P]rovided for in section 1328(a) simply requires that for a claim to become dischargeable the plan must 'make a provision for' it, i.e., deal with it or refer to it."); see also supra, note 531.
} 
discharged when the debtor pays allowed claims in accordance with the plan. ${ }^{534}$ The government has up to 180 days after the order for relief to file a claim for taxes. ${ }^{535}$ Because priority tax claims are discharged under Chapter $13,{ }^{536}$ the government's failure to file a timely claim results in a permanent loss of tax revenue if the debtor completes plan payments and obtains a regular discharge.

This special loophole for unfiled claims should not have applied in Chapter 12 cases prior to the 2005 Act, because the government's claim for the pre-petition portion of year-of-bankruptcy taxes should have been entitled to eighth priority under the postpetition assessability rule, and therefore excepted from discharge under section 523(a)(1)(A). Since all claims excepted from discharge under section 523(a) are also excepted from the Chapter 12 discharge ${ }^{537}$ the government should have been able to collect the taxes from the debtor even if it failed to file a proof of claim. After the 2005 Act, however, the government's claim for pre-petition year-of-bankruptcy taxes will no longer be entitled to eighth priority and will thus no longer be excepted from discharge under section 523 (unless the debtor files bankruptcy on the last day of the tax year). The government's failure to file a claim in cases subject to the 2005 Act should result in dischargeability. Courts may well result to the flawed reasoning of the Bankruptcy Court in Wilkoff to avoid this result. ${ }^{538}$

The 2005 Act contains a new rule giving the government additional time to file a proof of claim for tax returns that the debtor is required to file post-petition. The new rule treats the government's claim as timely if filed within 60 days after the debtor files a return under new section $1308 .{ }^{539}$ Section 1308 requires the debtor to file tax returns "for all taxable periods ending during the 4-year period ending on the date of the filing of the petition" by the time of the first meeting of creditors. ${ }^{540}$ Presumably, the prepetition portion of year-of-bankruptcy taxes is a "period" that ended on the petition date, even

${ }^{534}$ See, e.g.,

In re Elstien, 238 B.R. 747, 756 (Bankr. N.D. Ill. 1999) ("If the plan provides for a debt, but the creditor fails to file a claim, the underlying debt will not be paid but will be discharged."); In re Osborne, 159 B.R. 570, 580 (Bankr. C.D. Cal. 1993), aff'd, 167 B.R. 698 (B.A.P. 9th Cir. 1994), aff'd, 76 F.3d 306 (9th Cir. 1996); In re Richards, 50 B.R. 339, 341 (E.D. Tenn. 1985); In re Rothman, 76 B.R. 38, 41 (Bankr.

E.D.N.Y. 1987) (tax claim discharged even where taxing authority did not know how much claim was at bar date - should have filed a motion for extension of time to file a claim); In re Hunt, 59 B.R. 718, 720 (Bankr. D. Me. 1986); In re Goodwin, 58 B.R. 75, 77 (Bankr. D. Me. 1986). Note that Congress amended section 502(b)(9) in 1994 to make it clear that late-filed claims are subject to discharge, overruling earlier cases like In re Hausladen, 146 B.R. 557, 560 (Bankr. D. Minn. 1992). Bankruptcy Reform Act of 1994, Pub. L. No. 103-394, 108 Stat. 4106 (1994).

53511 U.S.C. $\$ 502($ b)(9) (claim filed by government within 180 days after order for relief, or such longer period as may be provided by the Rules of Bankruptcy Procedure, is "timely"); see also In re Gardenhire, 209 F.3d 1145, 1148 (9th Cir. 2000) (equitable tolling of the 180 day period is not available).

${ }^{536}$ See 11 U.S.C. $§ 1328$ (a) (not excepting from regular Chapter 13 discharge claims excepted from discharge under 11 U.S.C. $\S 523(\mathrm{a})(1))$.

${ }^{537} 11$ U.S.C. $\S \S 1228(\mathrm{c})(2), 1328(\mathrm{c})(2)$; In re Anderson, 228 B.R. 844, 846-47 (Bankr. W.D. Va. 1998) (priority tax claims not discharged by Chapter 13 hardship discharge, even where government failed to file a proof of claim).

${ }^{538} 2001$ Bankr. LEXIS 124, discussed supra beginning at note 400.

539 11 U.S.C. $\S 502($ b)(9).

${ }^{540}$ See 11 U.S.C. $\$ 341$ (first meeting of creditors). Note that the meeting of creditors can be held open by the trustee, or tolled by the court, in certain circumstances. 11 U.S.C. $\S 1308$ (b). 
though the tax year had not ended on the petition date. However, the statute only applies "if the debtor was required to file a tax return under applicable non-bankruptcy law.",541 Since it would be rare that the debtor would have been required to file a return for yearof-bankruptcy taxes by the time of the first meeting of creditors (even if it is extended), the statute appears to be inapplicable to year of bankruptcy taxes. Therefore, the general rule requiring the government to file a claim within 180 days after the order for relief ${ }^{542}$ appears to be the applicable rule for the prepetition portion of year of bankruptcy taxes.

This 180 day deadline puts the government in a difficult spot. If the government fails to file a claim, the Chapter 13 plan should effectively discharge the liability for prepetition year-of-bankruptcy taxes. Yet, the government may not know how much the claim is at the time of the filing deadline because the debtor may not have yet filed a return. In addition, the government may wish to continue to argue, as it has previously argued, that year-of-bankruptcy taxes constitute post-petition debts that are not discharged. The government may be able to avoid the Catch-22 by filing a protective claim. The protective claim could say something like this:

The government files this proof of claim to protect its rights in the event the court determines that the government has a prepetition claim for taxes owing on the debtor's prepetition income earned during the calendar (or fiscal) year in which the debtor filed bankruptcy. It is the government's contention that it has a postpetition claim against the debtor for all taxes incurred in the year of bankruptcy, and that this claim will not be discharged by any provision of the Bankruptcy Code. However, if the court determines that the government has a prepetition claim for some portion of the taxes incurred by the debtor in the year of bankruptcy, the government hereby asserts a claim in an unliquidated amount for such taxes. The claim is unliquidated because the debtor has not filed a tax return for the year in which the debtor filed the petition initiating this case.

A timely-filed protective claim should protect the government's rights. However, those rights have been severely curtailed by the 2005 Act, since the government's claim for the prepetition portion of year of bankruptcy taxes can no longer be entitled to eighth priority. Therefore, the debtor should be able to treat the tax claim in the same manner as any other dischargeable general unsecured claim.

\section{CONCLUSION.}

It is fair to assume that most debtors who file bankruptcy will owe income taxes for the year of bankruptcy. With more than one million bankruptcy cases filed each year, ${ }^{543}$ the laws providing for the treatment of year-of-bankruptcy tax claims affect many people. Laws that affect so many people should be clear and easy to apply.

54111 U.S.C. $\S 1308(\mathrm{a})$.

54211 U.S.C. $\$ 502(\mathrm{~b})(9)$.

543 See supra note 364. 
Unfortunately, this article illustrates just how complicated and confusing it is to determine how the government's claims for income taxes incurred by the year of bankruptcy will be treated.

The treatment of taxes owing by the debtor in the year of bankruptcy is straightforward only if an individual debtor in a case under either Chapter 7 or 11 makes the election to split the year of bankruptcy into two tax years, because the separate returns establish the amount of taxes for the prepetition and post-petition periods. ${ }^{544}$ Equally importantly, when an eligible debtor timely makes the split-year election, the priority rules will properly treat the government's claim for taxes shown on the prepetition return as an eighth priority claim, and properly treat the taxes shown on the post-petition return either as an administrative priority claim (if the income is usable by the bankruptcy estate), or as a personal obligation of the debtor (if the income belongs to the debtor free of creditors' claims under the debtor's fresh start). ${ }^{545}$ All is right in the world if the election is made.

However, not every debtor makes or is eligible to make the split-year election. The treatment of tax claims in the year of bankruptcy becomes highly confusing and uncertain whenever an individual debtor in a Chapter 7 or 11 case does not make the split-year election, and whenever a debtor is unable to make the election - either because the debtor is not an individual, or because the individual debtor has filed a petition under Chapters 12 or 13 of the Bankruptcy Code. ${ }^{546}$

Prior to the 2005 Act, the courts struggled to develop a coherent theory for the treatment of the government's claim for taxes incurred in the year of bankruptcy, but failed miserably. For individual Chapter 7 debtors who do not make the split-year election, the courts concluded that the government's claim for the entire year's taxes constitutes a personal obligation of the debtor and not an obligation of the debtor's bankrutpcy estate. ${ }^{547}$ The courts also recite this rule in Chapter 11 cases, but then to avoid the Chapter 11 discharge provisions somehow transmute the non-estate obligation into a claim that must be paid by the estate under a plan of reorganization. ${ }^{548}$ In reaching these results, the courts simply ignore the broad definition of a "claim" contained in the Bankruptcy Code, and the long line of cases outside of the tax area interpreting when a bankruptcy "claim" arises. ${ }^{549}$ A proper analysis would require the courts to recognize that the government's claim for taxes on prepetition income arises when that income is earned, even though the claim is unliquidated because the precise amount of taxes cannot be determined, and even though the claim is unmatured and contingent because future events occuring on or before the end of the year may offset the tax liability. ${ }^{550}$ Under the non-tax cases, the courts would be required to allocate the year's taxes between the prepetition and post-petition periods on the basis of time. ${ }^{551}$ To reach their conclusion that the government's claim is cognizable only outside of bankruptcy, the courts simply

\footnotetext{
${ }^{544}$ See discussion supra beginning at page 19.

${ }^{545} \mathrm{Id}$.

${ }^{546}$ See discussion supra beginning at pages 23 and 29.

${ }_{547}^{5}$ See discussion supra beginning at page 29.

548 See discussion supra beginning at page 59.

${ }^{549}$ See discussion supra beginning after note 217

${ }^{550} \mathrm{Id}$.

${ }^{551}$ See discussion supra beginning after note 186.
} 
ignored the rules that have been consistently applied in bankruptcy outside of the tax sphere. $^{552}$

For corporate debtors, the courts have held that the taxes must be divided between the prepetition and post-petition periods, with the prepetition taxes entitled to eighth priority. ${ }^{553}$ The courts have been unable explain precisely how the annual tax liability is to be divided between the prepetition and post-petition periods, and have differed on the theory for granting eighth priority rather than first priority to the taxes. ${ }^{554}$ Some courts have held that even though all of the year's taxes are deemed to arise post-petition, the post-petition assessability rule applies to subordinate the government's claim to eighth priority ${ }^{555}$ (even though the courts have unanimously held in other contexts that the postpetition assessability rule does not apply to post-petition taxes ${ }^{556}$ ). Other courts have suggested that the prepetition portion of the year's taxes arises prepetition, not postpetition, and therefore falls within the eighth priority post-petition assessability rule. ${ }^{557}$ No court has adequately explained how under the statutory language such different results can arise in corporate and individual cases.

The 2005 Act has eliminated eighth priority for taxes incurred in the year of bankruptcy unless the debtor makes a split-year election or files bankruptcy on the last day of the debtor's tax year. ${ }^{558}$ It is unclear whether the 2005 Act will have any effect on non-electing individual debtors. If the courts continue to follow the "non-claim" theory of the individual Chapter 7 cases, ${ }^{559}$ the changes made by the 2005 Act will likely have no effect because the government's claim was not previously entitled to priority. If the courts re-examine the "non-claim" theory, as they should, ${ }^{560}$ the 2005 Act could result either in the prepetition portion of year-of-bankruptcy taxes being treated as first priority administrative expenses, or as dischargeable general unsecured claims. ${ }^{561}$

The changes made by the 2005 Act will wreck havoc under either of the theories used in corporate cases. By moving language in the statute, Congress has made it clear that eighth priority can only be granted to claims for tax years ending on or before the petition date. ${ }^{562}$ The tax year in which bankruptcy is filed will end on or before the

\footnotetext{
${ }^{552} \mathrm{Id}$.

${ }_{553}^{55}$ See discussion supra beginning at page 23.

${ }^{554} \mathrm{Id}$.

${ }^{555}$ See discussion supra beginning at note 154.

${ }^{556}$ See discussion supra at note 136.

${ }^{557}$ See discussion supra beginning at note 164.

55811 U.S.C. $\$ 507(\mathrm{a})(8)(\mathrm{A})$ (2005), discussed supra beginning at page 41.

${ }^{559}$ See discussion supra beginning at page 29.

${ }^{560}$ See discussion supra beginning after note 217

561 The government's tax claim for the pre-petition portion of year-of-bankruptcy taxes can be treated as a first priority administrative expense only if the claim is "incurred by the [bankruptcy] estate." See 11 U.S.C. $\S 503(b)(1)(B)(i)$ (2005). Because the taxes were incurred on prepetition income, if the courts reexamine the law and determine the government's claim to exist prepetition, the claim should not be entitled to first priority as an administrative expense because the estate did not even exist when the taxes were incurred. See 11 U.S.C. $§ 541$ (a) (bankruptcy estate created upon commencement of bankruptcy case). Because the 2005 Act has eliminated eighth priority for taxes incurred in tax years ending post-petition (see 11 U.S.C. $\S 507(\mathrm{a})(8)(\mathrm{A}))$, there would be no other basis for granting priority to the government's claim for taxes incurred on prepetition income priority. Therefore, the government's claim should be a general unsecured non-priority claim, which would be subject to discharge. See discussion supra beginning at page 46.

56211 U.S.C. $\S 507(\mathrm{a})(8)(\mathrm{A})(2005)$, discussed supra beginning at 41.
} 
petition date only if the debtor happens to file bankruptcy on the last day of the tax year (or for individual debtors when the split-year election is made, in which case the prepetition partial tax year will end on the petition date). The change made by the 2005 Act make it impossible for the courts to apply the post-petition assessability rule to corporate year-of-bankruptcy taxes whenever the debtor files bankruptcy in the middle of a tax year. ${ }^{563}$ With the 2005 Act's elimination of eighth priority, it would appear that those courts treating the prepetition portion of the year's taxes as arising prepetition (which is the proper analysis under the Bankruptcy Code's definition of a "claim") 564 will be required to treat the government's claim for pre-petition year-of-bankruptcy taxes as a dischargeable general unsecured claim, while those courts treating the government's claim as arising post-petition ${ }^{565}$ will have to struggle to determine whether the government's claim for taxes on income earned before the estate was in existence will be treated as first priority administrative expenses "incurred by the estate," 566 or as a nonpriority post-petition claim (which would have no special protections in Chapter 11, and would presumably be subject to discharge).

The situation for Chapter 13 debtors and the government is even more confusing. If the courts follow the theory of the corporate cases, as the court in In re Michaelson $\mathrm{did}^{567}$ then after the 2005 Act the government will likely have a dischargeable general unsecured claim for the prepetition portion of year-of-bankruptcy cases. Under the theory in Michaelson, ${ }^{568}$ if the government fails to file a proof of claim, it will likely receive no distribution. On the other hand, if the courts follow the theory of the nonelecting individual debtor cases, as the court in In re Wilkoff did, ${ }^{569}$ then after the 2005 Act the government will not have a claim against the estate at all, unless the government elects to file a proof of claim under section 1305(a). If the government elects to file a proof of claim under section 1305(a), and the theory of Wilkoff is adopted, then the government's claim will be non-priority and dischargeable. ${ }^{570}$ Thus, under Michaelson theory the government must file a claim to protect its rights, while under the Wilkoff theory the government will forefeit substantial rights by filing a claim. Until the situation is resolved, maybe the government's only course of action is to rely on alternative pleading. The government could file a protective statement saying that it does not elect to file a proof of claim under section 1305(a) if the court follows the theory of Wilkoff, but herewith files a proof of claim if court follows the theory of Michaelson. ${ }^{571}$

Regardless of how the courts interpret the 2005 Act, this article points out the need for Congress to re-examine the statutory rules. The existing statutory rules are overly complex and vague, forcing debtors to decide whether to make the split-year election without being able to understand the consequences of doing so. The uncertainty

\footnotetext{
${ }^{563}$ This is because only individuals can make the split-year election. See I.R.C. $§ 1398(a)$. Therefore, unless a corporate taxpayer files bankruptcy on the last day of its tax year, the taxpayer's tax year will end post-petition.

${ }_{564}$ See discussion supra beginning at note 164.

${ }^{565}$ See discussion supra beginning at note 154 .

${ }^{566}$ See discussion supra note 561.

${ }^{567}$ See discussion supra beginning at note 399.

${ }^{568} \mathrm{Id}$.

${ }^{569}$ See discussion supra beginning at note 402 .

${ }^{570} \mathrm{Id}$.

${ }^{571}$ See discussion supra following note 542 .
} 
has created in the past, and will create after the changes made by the 2005 Act, unnecessary litigation over the meaning of the law. Equally important, the ambiguities in the statute have caused the courts to interpret the existing tax rules in ways inconsistent with the rules applicable to all other bankruptcy claims.

In enacting a new statute, Congress should focus on when the government's claims should be given priority over other creditors, and when those claims should be non-dischargeable. If Congress feels that the government's claims for recently-incurred taxes should be given priority over other general unsecured claims, it should make the law clear and easy to apply by specifying an easily-determinable time period for priority. Similarly, if Congress feels that the government's claims for recently-incurred taxes should also be made non-dischargeable, along with claims due to the debtor's fraudulent conduct, it should enact provisions to accomplish these objectives. The law would be greatly clarified and simplified if the priority and non-dischargeability rules were written to stand by themselves without referencing each other and without referencing the complex non-bankruptcy rules of limitations on assessment. The cross-references serve only to complicate the law and create anomalous results. In addition, Congress should require all debtors to file separate returns for the pre-bankruptcy and post-bankruptcy periods. It would then be a simple matter to treat the pre-bankruptcy tax liability as a priority or general unsecured claim in the same matter as all other pre-bankruptcy liabilities, and to treat the post-bankruptcy tax liability as an administrative claim if the income was available to the estate, and as a non-bankruptcy personal obligation of the debtor if the income belonged to the debtor as part of the debtor's fresh start. Until the statutory rules are fixed, the parties and the courts will have to do the best they can with a badly flawed statutory framework. 